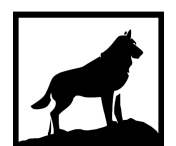

Michigan Technological

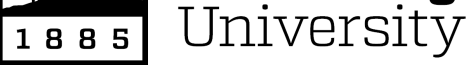

Michigan Technological University Digital Commons @ Michigan Tech

\title{
IMPACTS TO BIODIVERSITY AND ECOSYSTEM SERVICES FROM BIOENERGY DEVELOPMENT: A PAN AMERICAN EXPERIENCE
}

Colin Phifer

Michigan Technological University, ccphifer@mtu.edu

Copyright 2017 Colin Phifer

Recommended Citation

Phifer, Colin, "IMPACTS TO BIODIVERSITY AND ECOSYSTEM SERVICES FROM BIOENERGY

DEVELOPMENT: A PAN AMERICAN EXPERIENCE", Open Access Dissertation, Michigan Technological University, 2017.

https://doi.org/10.37099/mtu.dc.etdr/533

Follow this and additional works at: https://digitalcommons.mtu.edu/etdr

Part of the Terrestrial and Aquatic Ecology Commons 


\title{
IMPACTS TO BIODIVERSITY AND ECOSYSTEM SERVICES FROM BIOENERGY DEVELOPMENT: A PAN AMERICAN EXPERIENCE
}

\author{
By \\ Colin C. Phifer

\begin{abstract}
A DISSERTATION
Submitted in partial fulfillment of the requirements for the degree of DOCTOR OF PHILOSOPHY

In Forest Science
\end{abstract}

MICHIGAN TECHNOLOGICAL UNIVERSITY

2017

(C) 2017 Colin C. Phifer 
This dissertation has been approved in partial fulfillment of the requirements for the Degree of DOCTOR OF PHILOSOPHY in Forest Science.

School of Forest Resources and Environmental Science

$\begin{aligned} \text { Dissertation Co-Advisor: } & \text { David Flaspohler } \\ \text { Dissertation Co-Advisor: } & \text { Christopher Webster } \\ \text { Committee Member: } & \text { Chelsea Schelly } \\ \text { Committee Member: } & \text { Daniel Gruner } \\ \text { School Dean: } & \text { Terry Sharik }\end{aligned}$


Dedicated to Tina and River Phifer, my family

(Jasper, you too) 


\section{Table of Contents}

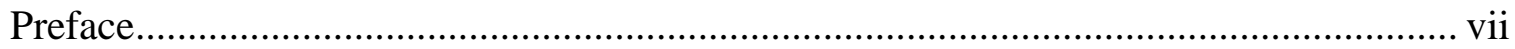

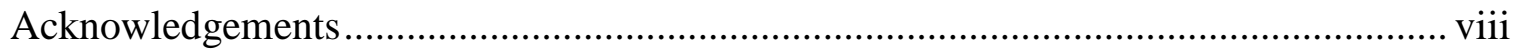

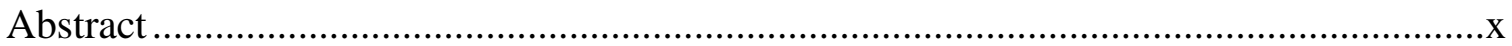

1. Project background and research design .....................................................

Ecological and social sustainability of bioenergy in the Americas ............................1

Bees and birds: ecosystem services providers and harbingers of change ..................2

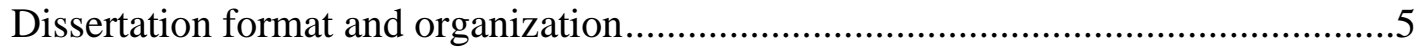

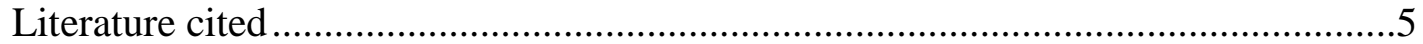

2. Bird community responses to afforested eucalyptus plantations in the Argentine

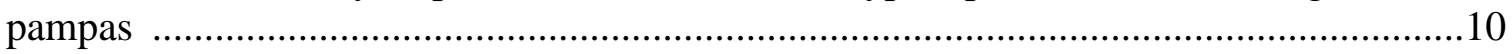

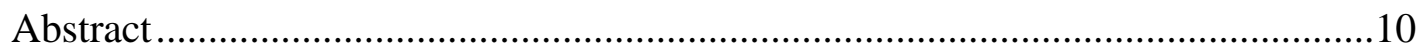

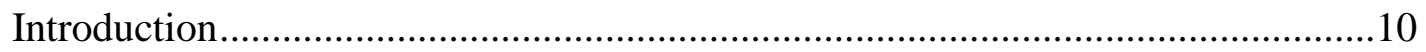

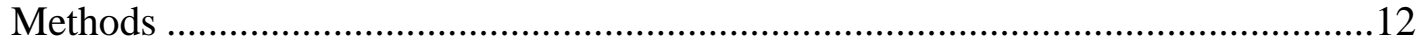

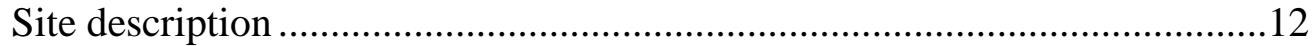

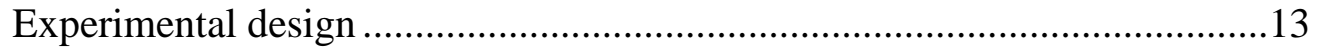

Field methods ...................................................................................13

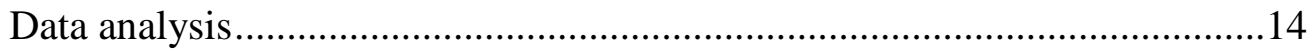

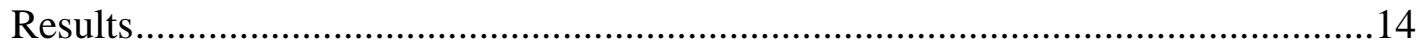

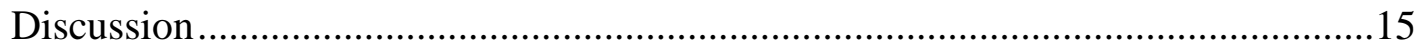

Implications of expanding afforestation on avian communities and ecosystem services

Edge effects of afforestation on pampas bird communities .........................17

Management recommendations and future research needs ..........................18

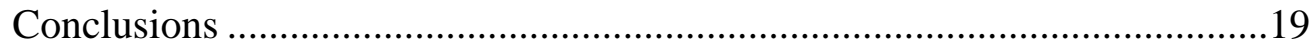

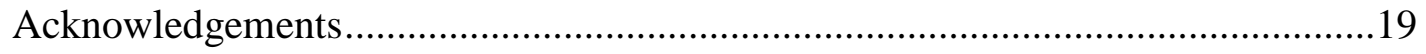

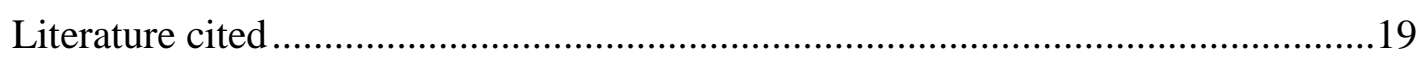

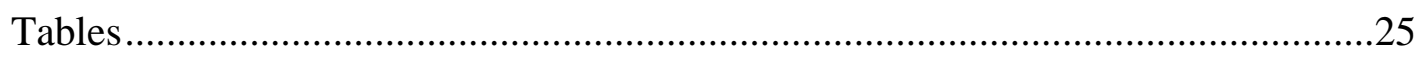

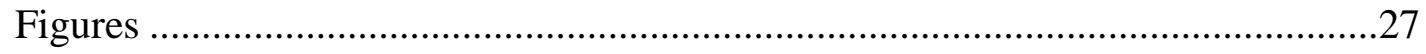

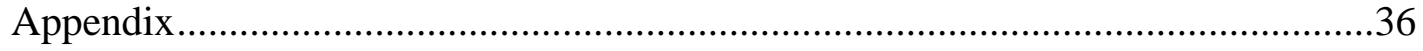

3. Impact of land-use change and afforested plantations on native bees in northeastern

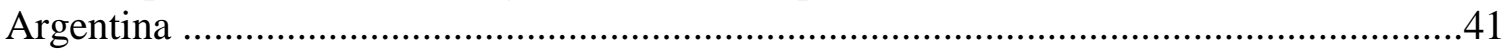

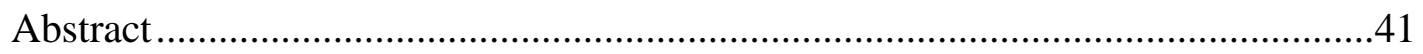




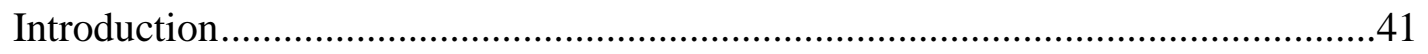

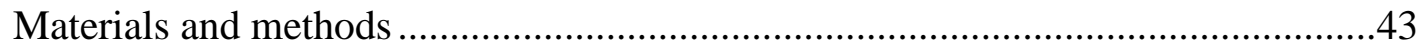

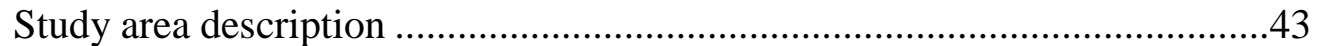

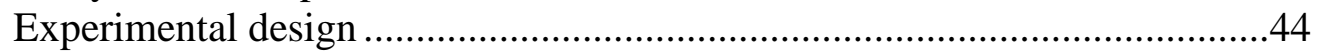

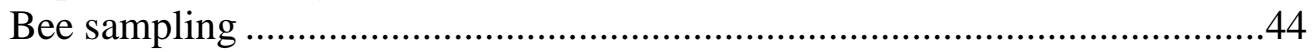

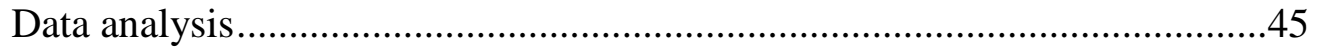

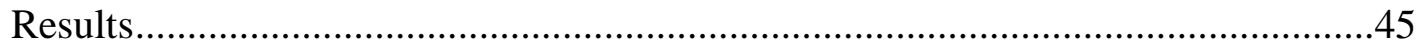

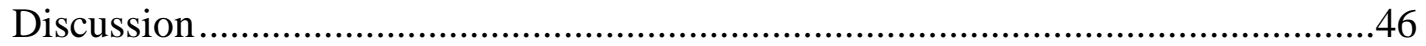

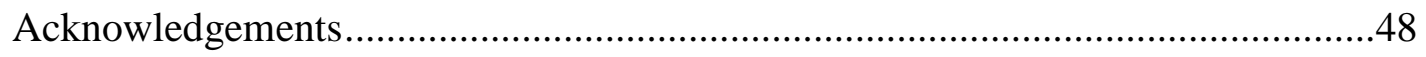

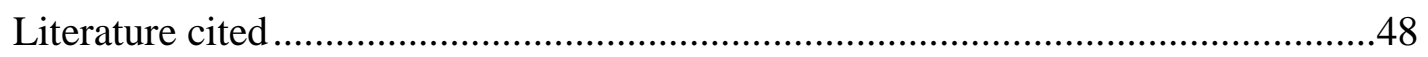

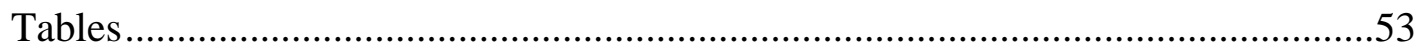

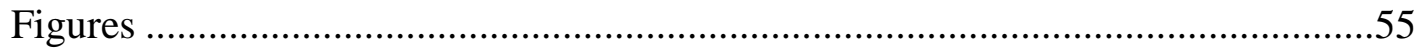

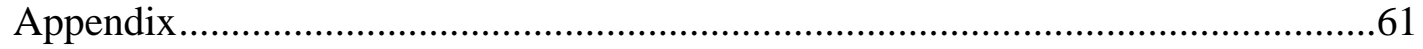

4. Impact of afforested eucalyptus plantations on ecosystem services in Entre Ríos,

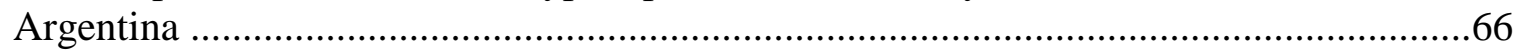

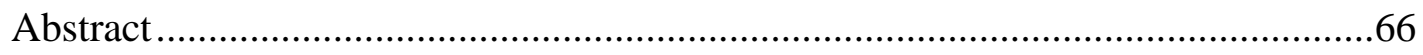

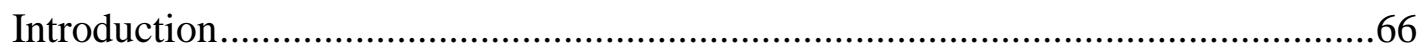

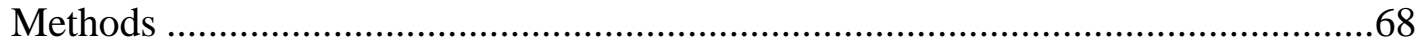

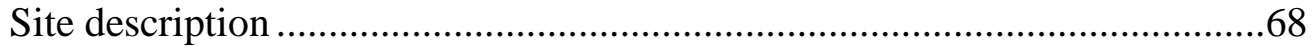

Baseline mapping .........................................................................69

Community interviews and survey ....................................................69

Scenario development ecosystem service evaluation ................................70

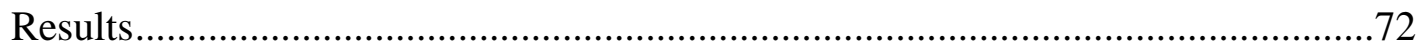

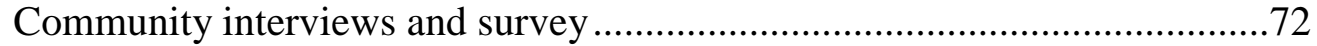

Ecosystem service evaluation ................................................................73

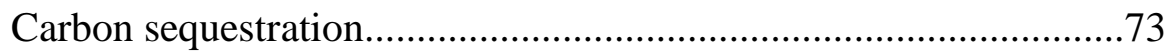

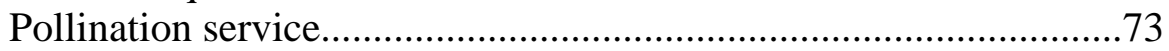

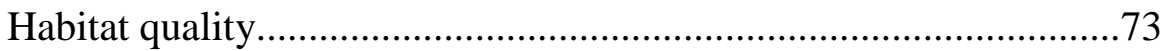

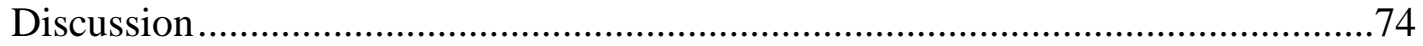

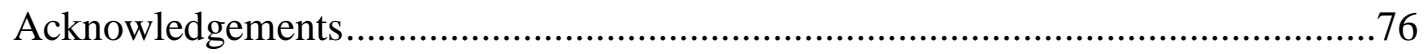

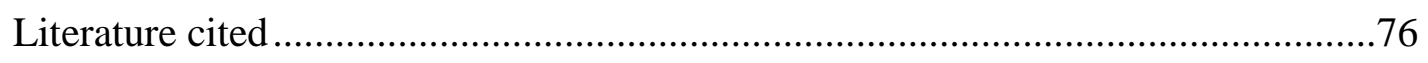

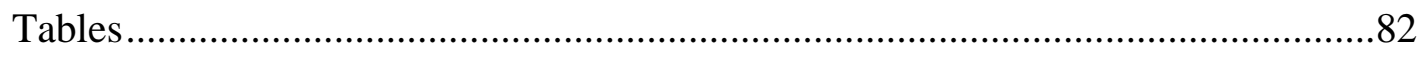

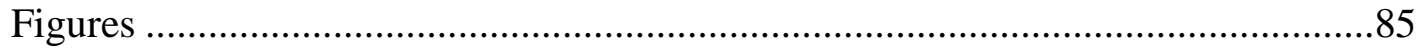

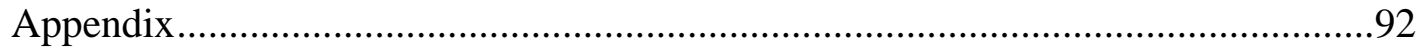


5. Impacts of stand age on bee and wasp diversity in aspen forests in northeastern

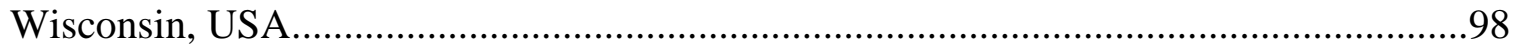

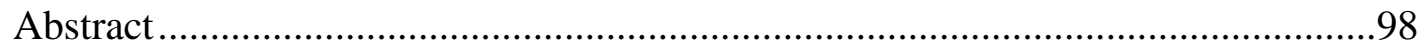

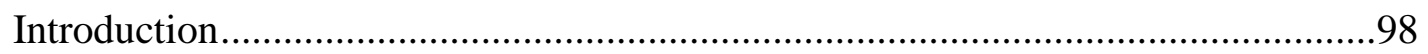

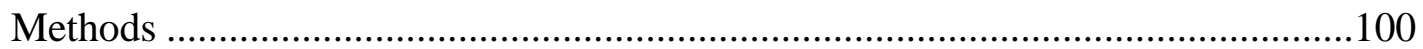

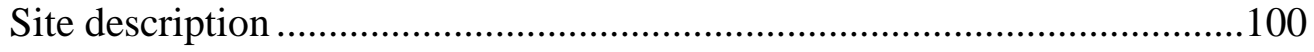

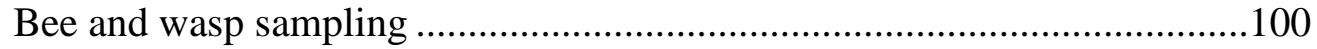

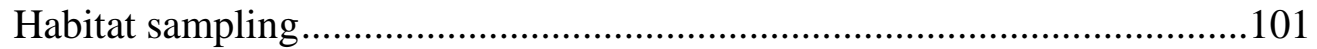

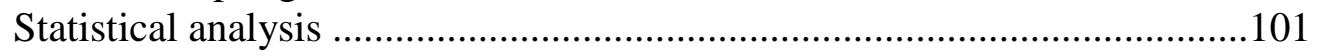

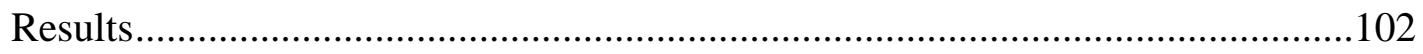

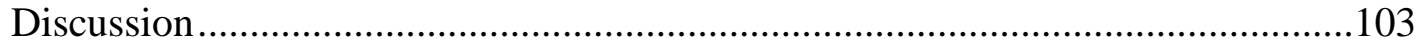

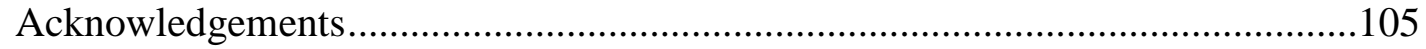

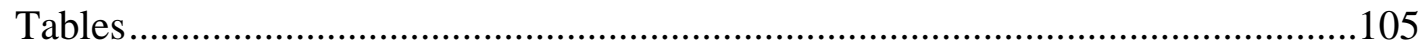

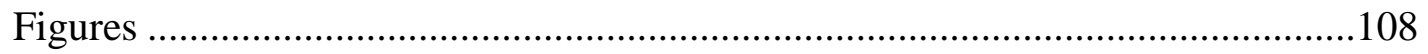

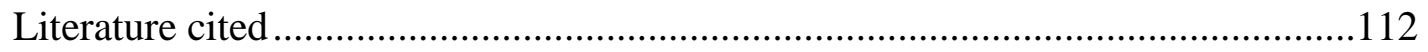

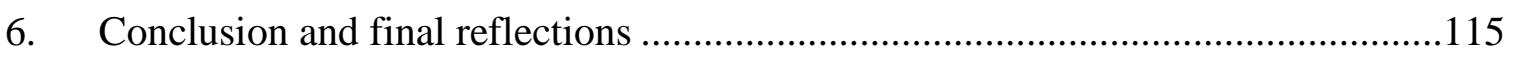

The social and ecological sustainability of bioenergy ......................................115

Interdisciplinary research - personal reflection...............................................116

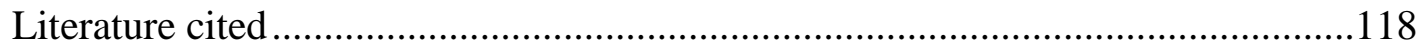

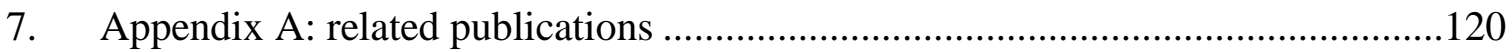

A case study of strategies for fostering international, interdisciplinary research ...120

Forest reserves and riparian corridors help maintain orchid bee (Hymenoptera:

Euglossini) communities in oil palm plantations in Brazil .................................120

Oil palm plantations affect movement behavior of a key member of mixed-species

flocks of forest birds in Amazonia, Brazil .........................................................121

Diversity and abundance of bees (Hymenoptera: Apoidea) in oil palm agroecosystems and cultivated pastures in Tabasco, Mexico

Barriers and solutions to conducting large international, interdisciplinary research

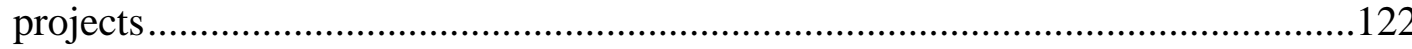

Transatlantic wood pellet trade demonstrates telecoupled benefits......................122

Short-rotation aspen forest management impacts on avian communities: implications for bioenergy development 


\section{Preface}

Chapters 1 and 6 serve as the "bookends" of this work, a place to set the scene for this research and a summary the major themes and lessons learned.

Chapter 2 was published in Biodiversity and Conservation, which maintains copyright for this chapter. Study design, field work, data analysis and writing was led by Colin Phifer. Jessie Knowlton contributed to the design, field work and logistics and writing. Christopher Webster and David Flaspohler helped with statistical analysis, research direction and greatly improved the writing. Julian Licata assisted in study design and logistics and writing of this chapter, and served as a key collaborator in Argentina.

Chapter 3 will be submitted to Agriculture, Ecosystems and Environment. Research design, field work and analysis was led by Colin Phifer with Pablo Cavigliasso serving as project co-lead. Pablo contributed to the research design and field work and was solely responsible for bee species identification, as well as some parts of the data analysis. Jessie Knowlton also assisted in design and field research. Daniel Gruner helped with statistical analysis and writing.

Chapter 4 is intended for Sustainability. Colin Phifer conducted the GIS and ecosystem service analysis and was responsible for the majority of the writing. Erik Nielsen, Chelsea Silva, Renee Sanders and Jesse Abrams were responsible for social surveys and interviews and analysis. Santiago Veron, Diego Abelleyra, and Tamara S. Propato completed the remote sensing and land-use/land-cover classification. Michelle Brill Cisz completed soil sampling for carbon sequestration values in plantations and Pablo Cavigliasso helped with bee biodiversity sampling. Jessie Knowlton also assisted with bird biodiversity sampling (see above) and also writing and conceptual design. David Flaspohler and Christopher Webster assisted with writing and editing. Chelsea Schelly helped frame the research and with writing and placing the social science contribution in context.

Chapter 5 is intended for Forest Science or other forest ecology publication. Colin Phifer completed the field research, insect identification, data analysis and majority of the writing. Christopher Webster assisted with experimental design, analysis and writing. Bryan Murry also assisted with data analysis. Cindy Fiser also assisted in data collection, insect identification and editing. David Flaspohler assisted in writing and editing. Daniel Gruner helped with statistical analysis and writing.

Chapter 7 serves as the Appendix and includes the titles, abstracts and citations for related peer-reviewed publication that I co-authored while part of this project. These papers relate to my own work on bioenergy development in Mexico and Brazil, and interdisciplinary team science. I include them here to help give a fuller perspective of my work and scholarship from the last four years. 


\section{Acknowledgements}

This research was financially supported by the National Science Foundation Partnerships for International Research and Education program (grant num. 124344), which has been led by Dr. Kathleen Halvorsen at Michigan Technological University. The support of the USDA McIntire-Stennis fund also provided needed support, particularly for field research in Argentina. In addition, I am extremely thankful for MTU's Graduate School Finishing Fellowship, which provided me with one semester of support. The InterAmerican Institute for Global Environmental Change also supported this and related work focusing on improving interdisciplinary collaborations within our team. I also received numerous travel grants and research awards from MTU's Ecosystem Science Center and MTU's Graduate Student Government. I am also thankful to the numerous travel grants I received from professional societies to attend and present at research conferences.

The research presented here is part of a larger interdisciplinary, international project that is focused on the social and ecological sustainability of bioenergy development in the United States, Argentina, Brazil and Mexico. This team was led by Dr. Halvorsen, with complementary leadership from many other researchers in each country. Many, many people contributed to this project, and I cannot thank them all, but my work is only possible because of the contributions of the whole team. The work presented here is, indeed, a group effort.

I have been blessed to have the support and advice of Drs. David Flaspohler and Christopher Webster, my co-advisors, and Drs. Chelsea Schelly and Daniel Gruner, members of my committee. With their help, I have been able to knit together the distinctive research projects from each country into something greater than the sum of its parts. Project principle investigator, Dr. Halvorsen, was also instrumental in my project and provided me guidance, leadership opportunities, and training in interdisciplinary science. I also worked closely with Dr. Jessie Knowlton on this project, particularly in Argentina and Brazil, and I can say truthfully that this degree would not be possible without her help, support and understanding - thank you, Jessie. (Special thanks to Phil LoCicero, too, for his encouragement!) I emerge from this project as a stronger scientist from this four-year trek across disciplinary and country boundaries.

My work had the added challenge of working in two countries. In Argentina, I am deeply indebted to a whole team of wonderful collaborators: Pablo Cavigliasso, Julian Licata, Erika Adams, Santiago Veron, Diego Abelleyra, Tamara Sofia Propato, Chelsea Silva, Erik Nielson, and all the landowners who allowed us work there. In particular, and with special thanks, to Pablo: this work is also his work, and our friendship will last. Sam Oliveria also helped collect bird data. In the United States, the wonderful staff at the University of Wisconsin Kemp Field Station, made our work possible. All the travel, staffing and (often random) purchases I made on behalf of this research was only possible because of the outstanding staff support from MTU, particularly Andrea Longhini, Marjorie Lindley, and Phyllis Williamson. 
I would also like to thank the University of Oregon's Institute for Sustainable Environment for hosting me while I finalized this degree. The collaborations and friendships with Drs. Heidi Huber-Stearns, Jesse Abrams and Cass Moseley were particularly enriching. This place has been my other home, and I appreciate the support and encouragement. Writing is hard and you helped me overcome the many (often selfimposed) road blocks.

I would like to thank all the students involved in this research project, including Michelle Brill Cisz, Jose Lopez, and Erin Pischke, Tatiana de Souza, Renee Sanders and Chelsea Silva. I am particularly thankful to my undergraduate interns: Cynthia Fiser, who exceeded all expectations as my field and lab assistant; Nia Becker, who worked to identify bees with me and came to Brazil; and Gina Testa, who designed her own research project. Advising and working with these three undergraduates was one of my favorite parts of this project. I am confident they all have bright futures ahead.

I thank my whole family that often-wondered out loud "You're still in school?" and openly wondered the wisdom of this choice. Nonetheless, they supported and loved me, and I am thankful to May Phifer, and Bill and Linda Hilbert for all their help and support (and the snow tires they gave me for my birthday while in Michigan!). I also thank Rick and Jean Throm for being supportive and always asking, "how can I help?" and following through while we were in Michigan.

Most importantly: I would only be able to do this work and research because of the support, trust and love of my wife, Tina, and with the inspiration, love and energy of my son, River. Thank you. I love you both so much and I am so thankful that you both accompanied me on this long, convoluted and often frustrating journey. I couldn't do it without you two, and the only reason I'm finishing this degree is because of River's insistence that "We are both scientists." Special thanks to Jasper the Cat for sitting beside me while I worked on this project in the wee hours of the night or early morning, and for reminding me that kindness, food, and love are more important than another line on one's CV. OK? On with the show!.. 


\begin{abstract}
As part of a broader project that evaluated the social and ecological sustainability of bioenergy, I studied the effects of bioenergy associated land-use change and management on native bees and birds in two bioenergy-producing countries, the United States and Argentina. In Argentina, I worked in Entre Ríos province where eucalyptus (Eucalyptus spp.) plantations are being planted. These fast-growing trees are replacing pasture and annual crops, the current dominant land use. I surveyed for native bees and birds in pastures/annual crops and large-scale eucalyptus plantations, as well as mixed-use farms and native espinal savannas. Both birds and bees declined in the large-scale plantations in terms of species richness and abundance compared to the other land uses in the region. Avian biodiversity was richest in the espinal savanna with intermediate values in the mixed-use and pasture/annual crops. In contrast, pastures/annual crops and mixed-use farms supported more bees than the espinal. I also detected distinct communities of birds and bees in each land use surveyed. I also modeled ecosystem services in for this region, specifically carbon sequestration, pollination service and habitat quality. I considered the current baseline map and two future scenarios: eucalyptus expansive and community preferences. The models predict that the expansion of the plantations results in decreases in pollination service and habitat quality while increasing potential carbon sequestration. Collectively, these results demonstrate the need to carefully consider the effects of feedstocks on species and ecosystem services. In the United States, I worked in northeastern Wisconsin and studied the effects of aspen (Populus spp.) forest stand age on native bees and other members of the Hymenoptera using a chronosequence of noretention aspen stands. Discrete bee and wasp communities were detected along the forest successional age gradient, but bee and wasp species richness and abundance did not decline with forest age as hypothesized. This work illustrates a successional pattern in bee community composition following disturbance and suggests both young and old forest stands are necessary to support bee biodiversity. Lastly, I conclude with a summary of my research and suggestions on how to be an effective team member in an interdisciplinary research group.
\end{abstract}




\section{Project background and research design}

\section{Ecological and social sustainability of bioenergy in the Americas}

Human induced climate change is caused by the increases in greenhouse gases like carbon dioxide (IPCC 2014). Bioenergy - energy derived from non-fossil fuel based plant materials - can be part of the solution to slow greenhouse gas emissions because plants absorb carbon dioxide while growing, thus closing the "carbon loop" (Deng et al. 2015). Bioenergy is can be made from a variety of feedstocks, but like any other crop or land-use change, it can affect natural and human communities positively or negatively (Dale et al. 2014). The fact that bioenergy can come from many sources means different nations are exploring bioenergy's potential to both reduce greenhouse gases, but also provide economic development and ecological sustainability (Dale et al. 2014).

Worldwide, the market for bioenergy production is expected to more than double by 2050 (Immerzeel et al. 2013). Bioenergy feedstocks can be converted into solid fuels, like biomass wood pellets and chips, or liquid biofuels like biodiesel. Ethanol from corn or sugar is the current dominant bioenergy feedstock but there is growing demand for second-generation bioenergy crops that provide greater yields and more energy per volume to meet the expected market and government mandates for renewal energy and climate change mitigation (IPCC 2014). Bioenergy feedstock production can have negative ecological impacts, including potential net carbon emissions increase compared to fossil fuels and loss of biodiversity (Ben Phalan 2009; REPO et al. 2010; Fargione et al. 2010). Most bioenergy feedstocks require large amounts of land to be profitable and feasible, which impacts water budgets, soil fertility and biodiversity, potentially both positively and negatively depending on the feedstock, the prior habitat and the management system (Immerzeel et al. 2013). Biodiversity is a fundamental part of ecosystem health and provides for multiple ecosystem services that directly relate to human well-being Changes in land use as a result of bioenergy development that impacts biodiversity, may in turn affect ecosystem services through direct and indirect interactions (Fargione et al. 2008; Polasky et al. 2010; Fargione et al. 2010; Lawler et al. 2014).

To understand the potential impacts from bioenergy development, Michigan Technological University led a Pan-American evaluation of the social and ecological sustainability of bioenergy in four countries (Argentina, Brazil, Mexico and the United States) where bioenergy production has increased rapidly in the last ten years (Kline et al. 2015a). The MTU team was comprised of social, natural and physical scientists and engineers that worked together to consider how bioenergy feedstocks changed communities and how do the many parts of a linked social-ecological system interact. In each country, the research team applied a control/treatment design that contrasted communities actively developing bioenergy feedstocks with those communities that are using landscapes in a traditional manner, and where appropriate, a reference ecosystem intended to represent a natural or semi-natural condition. The natural scientists focused 
on three aspects of ecological sustainability: water usage and water cycling, soil health and carbon sequestration, and biodiversity impacts of bioenergy feedstocks.

Within this established framework, I studied how bioenergy associated land-use change impacted birds, native bees and their associated ecosystem services as part of the biodiversity assessment in two countries, Argentina and the United States. In Argentina, large-scale afforested eucalyptus (Eucalyptus spp.) plantations are replacing pastures and annual croplands. The wood from these plantations can be chipped for biomass power plants, making the eucalyptus the bioenergy feedstock. In the United States, the MTU project worked in Wisconsin where naturally occurring aspen (Populus spp.) forests are a potential biomass fuel for nearby power plants, potentially shifting the landscape to forests of younger aspen. Both Argentina and the United States have active bioenergy markets and favorable government policies that will likely result in a significant bioenergy expansion in the future (Deng et al. 2015; Kline et al. 2015b). The results of my research on the biodiversity impacts are then one part of the broader MTU investigation into the social and ecological sustainability of bioenergy.

\section{Bees and birds: ecosystem services providers and harbingers of change}

For my dissertation, I selected birds and bees as my focus taxa because they directly provide ecosystem services, like pollination and pest control. These two taxa groups can be rapidly assessed and act as proxies for other species (Gardner et al. 2007). More generally, biodiversity as a whole is a foundational component of ecosystem services (Mace et al. 2012; Cardinale et al. 2012). Many ecosystem services are directly provided by species, and these species' patterns of abundance and richness are influenced by landuse decisions (Lawler et al. 2014), and consequently likely impact the delivery of service (Laterra et al. 2012).

Understanding how native bee populations respond to land-use change is critical since bees pollinate domesticated and wild plants. Nearly $90 \%$ of the world's flowering plants require some degree of animal-assisted pollination (Ollerton et al. 2011), making pollinators an intrinsic and deeply connected part of biodiversity. Moreover, pollinated crops provide both essential calories (Klein et al. 2007) and micronutrients (e.g. vitamin A, iron and folic acid) needed for human health, (Chaplin-Kramer et al. 2014; Ellis et al. 2015) directly linking human well-being to pollinator biodiversity. Economically, pollinators contribute to $75 \%$ of crop species, an ecosystem service estimated to be approximately $\$ 215$ billion worldwide (Gallai et al. 2009). Wild, unmanaged pollinators are a major source of this pollination service for many crops (Winfree et al. 2007). Crosspollinated crops also increase shelf life and nutrient quality of fruits (Klatt et al. 2013; 2014). Reliance on pollinators is likely to increase since pollinator-dependent crops are becoming more popular, making future food yields contingent upon vital biodiversitydependent service (Aizen et al. 2008; Garibaldi et al. 2013; 2016)

The growth in pollinator-dependent crops comes at a time of worldwide decline in native bee populations (Potts et al. 2010; Kennedy et al. 2013). The decline in bee populations is 
likely the result of the confluence of many factors that interact and reinforce one another (Goulson et al. 2015) including: agricultural intensification (Vanbergen \& Initiative 2013), climate change (Miller-Struttmann et al. 2015), diseases and invasive pests (Morales et al. 2013), and mixtures of herbicides, fungicides and insecticides (Whitehorn et al. 2012; Rundlöf et al. 2015; Hladik et al. 2016). Similar to native bees, managed honey bees in the United States are also stressed with losses to colonies nationwide (Lee et al. 2015). These two observations - increased demand for pollination service and decrease in supply of pollination services by bees - may lead to possible pollination decay for wild plants (Vamosi et al. 2006) and pollination deficit for crops, with increased rates of malnutrition in communities more dependent on pollination-dependent fruits and vegetables (Chaplin-Kramer et al. 2014; Ellis et al. 2015).

Bees are responsive to land-use change and their responses have been widely studied with an emphasis on local and landscape perspectives (Kennedy et al. 2013). With more than 20,000 species worldwide, it is impossible to study every species' response habitat change. Consequently, biologists use life-history or functional traits as a useful way to group and predict species responses habitat modifications (Williams et al. 2010). Williams et al. (2010) found that species' social structure (social or solitary), nesting location (above or below ground), and diet (pollen specialist or pollen generalist) were important predictors of species' responses to agricultural intensification, habitat fragmentation, fire and pesticides. Recent work suggests that bee abundance and richness are higher in more diverse landscapes and in landscapes that more closely resemble natural or undisturbed habitats (Kennedy et al. 2013). The stability of pollination services has also been shown to decline with increasing distance from natural and semi-natural habitats (Ricketts et al. 2008; Potts et al. 2010; Garibaldi et al. 2011). These broader landuse and land-cover analyses are capturing the local scale changes in floral resources, nest resources and overwintering habitats that influence bee communities (Kremen \& Ostfeld 2005; Williams et al. 2010). Just how bees perceive the availability of these habitats is a likely a function of home ranges and their capacity for long-distance flight (Greenleaf et al. 2007; E Benjamin et al. 2014). Local level and landscape level effects co-vary, and both appear to influence bees communities, suggesting a need to consider both perspectives (Lonsdorf et al. 2009; Kennedy et al. 2013).

Despite apparent declines in some species and populations of bees, notably bumblebees (Grixti et al. 2009), many species appear resilient with stable populations (Garibaldi et al. 2013). However, there exists few long-term studies on inter-year variation in bee populations and existing sampling efforts remain limited, which limits our ability to interpret how bees are responding to rapidly changing habitats (Lebuhn et al. 2012). Further, most studies focus upon species richness (the presence or absence of species) but not upon interacting communities of bees and other pollinators (Winfree et al. 2011).

Like bees, birds are also a major contributor to ecosystem services that benefit human well-being. For example, birds provide essential and economically valuable ecosystem services including pest control, seed dispersal, pollination, guano, and recreational value to humans (Wenny et al. 2011a; Sekercioglu 2012; Whelan et al. 2015). The ability of 
(most) birds to fly and their high energetic demands and thus appetites makes birds a highly mobile ecological force on landscapes, capable of responding to rapid changes in resource availability and landscape condition (Whelan et al. 2008). Some of the earliest research in ecosystem services focused on "economic ornithology" in the early $20^{\text {th }}$ century and how birds could contribute to pest management on farms (Whelan et al. 2008; Kronenberg 2014). The majority of birds are (at least partially) insectivorous, making them potential pest control agents (Whelan et al. 2015). Multiple studies confirm the pest-control effect of birds; farmers that conserve natural habitat adjacent to farms often see increases in crop yields and lower levels of insect damage (Karp et al. 2013). Birds are also important seed dispersers for native plants, with more than one-third of birds feeding on fruits and nuts and distributing seeds (Whelan et al. 2008). Lastly, more than 900 species of birds worldwide help pollinate plants, and there are numerous examples of long term evolutionary relationships between bird-pollinated flowers and birds (Kelly et al. 2010; Anderson et al. 2011) reinforcing central role some birds play in the maintenance and contribution to biodiversity patterns (Whelan et al. 2008; Wenny et al. 2011b; Whelan et al. 2015).

Birds can fly long distances, even migrate between continents, but local habitats also influence species survival and fitness. Of the approximately 10,000 species of birds, only a few prefer human-modified agricultural, suburban, or urban settings (Sekercioglu et al. 2007). However, some bird species will interact with and visit farm fields and modified habitats during part of their annual cycle (Tscharntke et al. 2008). In addition to land-use change, climate change can also affect species and these forces are already impacting avian communities with declines in current and projected habitat ranges (Barbet-Massin et al. 2011; Mantyka-Pringle et al. 2013; Meller et al. 2015). At present, however, the effects of land-use change have a greater impact than present-day climate change effects (Jetz et al. 2007). Similar to native bee research, recent efforts to identify ecological and life history traits of bird species have been used to develop predictive models of the effects of land-use change on species have found some common traits, and strong regional differences between temperate and tropical species (Newbold et al. 2012; Bregman et al. 2014). Larger bird species, frugivores, insectivores, and non-migratory resident species were more negatively impacted than migratory and smaller bird species. Tropical species were also found to be more sensitive to land-use change than temperate birds (Newbold et al. 2012; Bregman et al. 2014). Further, bird communities often responded to land-use change in non-linear ways, with thresholds for minimum habitat sizes (Bregman et al. 2014). The observed effect size and magnitude of the change in avian communities depends on the original and altered landscapes.

Land-use change, whether it be part of bioenergy development or urbanization, will continue worldwide so it is critical to understand species responses to lessen negative effects. Much of the existing research on land-use change focuses only on the species and does not consider the impacts to biodiversity-dependent ecosystem services. The gradual loss of species, community simplification or species extinction that provide ecosystem services may contribute to the loss of biodiversity-dependent ecosystem services, like pollination, pest control and seed dispersal ecosystem services (Isbell et al. 2011; Mace et 
al. 2012). Indeed, species-rich areas maintain greater ecosystem resilience and functions at multiple trophic levels than species-poor area (Byrnes et al. 2015), and these effects can compounded over time (Cardinale et al. 2012). The careful integration of commodity production and conservation action can minimize the impacts to biodiversity and ecosystem services without impacting human well-being or economic profitability (Daily et al. 2009; Cardinale et al. 2012; Howe et al. 2014; Posner et al. 2016).

\section{Dissertation format and organization}

Chapters 2-5 are intended for publication in peer-reviewed journals. Consequently, these chapters were organized and written in journal-specific styles, including framing the research question for different audiences. Each of these chapter contains the text, figures, tables, and literature cited necessary for publication. The preface that proceeds Chapters 2-5 explains the relative contributions of the multiple authors to each chapter. Chapter 6 is my summary of my research and thoughts on interdisciplinary team science. Appendix A includes the abstract and citation of other peer-reviewed publications that I contributed to as a co-author while part of this project. If published or under review prior to submitting my dissertation to the MTU Library, I noted the citation and copy-right information with a footnote on the first page of the chapter.

\section{Literature cited}

Aizen MA, Garibaldi LA, Cunningham SA, Klein AM. 2008. Long-Term Global Trends in Crop Yield and Production Reveal No Current Pollination Shortage but Increasing Pollinator Dependency. Current Biology 18:1572-1575.

Anderson SH, Kelly D, Ladley JJ, Molloy S. 2011. Cascading effects of bird functional extinction reduce pollination and plant density. Science.

Barbet-Massin M, Thuiller W, Jiguet F. 2011. The fate of European breeding birds under climate, land-use and dispersal scenarios. Global Change Biology 18:881-890.

Ben Phalan. 2009. The social and environmental impacts of biofuels in Asia: An overview. Applied Energy 86:S21-S29.

Bregman TP, Sekercioglu CH, Tobias JA. 2014. Global patterns and predictors of bird species responses to forest fragmentation: Implications for ecosystem function and conservation. Biological Conservation 169:372-383.

Byrnes JEK, Isbell F, Gamfeldt L, Griffin JN, Eisenhauer N, Hensel MJS, Hector A, Cardinale BJ, Duffy JE, Lefcheck JS. 2015. Biodiversity enhances ecosystem multifunctionality across trophic levels and habitats. Nature Communications 6:1-7.

Cardinale BJ et al. 2012. Biodiversity loss and its impact on humanity. Nature 486:5967.

Chaplin-Kramer R, Dombeck E, Gerber J, Knuth KA, Mueller ND, Mueller M, Ziv G, Klein A-M. 2014. Global malnutrition overlaps with pollinator-dependent micronutrient production. Proceedings of the Royal Society B: Biological Sciences 281:20141799-20141799.

Daily GC, Polasky S, Goldstein J, Kareiva PM, Mooney HA, Pejchar L, Ricketts TH, 
Salzman J, Shallenberger R. 2009. Ecosystem services in decision making: time to deliver. Frontiers in Ecology and the Environment 7:21-28.

Dale BE et al. 2014. Take a Closer Look: Biofuels Can Support Environmental, Economic and Social Goals. Environmental Science \& Technology 48:7200-7203.

Deng YY, Koper M, Haigh M, Dornburg V. 2015. Country-level assessment of long-term global bioenergy potential. Biomass and Bioenergy 74:253-267.

E Benjamin F, R Reilly J, Winfree R. 2014. Pollinator body size mediates the scale at which land use drives crop pollination services. Journal of Applied Ecology 51:440449.

Ellis AM, Myers SS, Ricketts TH. 2015. Do Pollinators Contribute to Nutritional Health? PLOS ONE 10:e114805. Public Library of Science.

Fargione J, Hill J, Tilman D, Polasky S, Hawthorne P. 2008. Land Clearing and the Biofuel Carbon Debt. Science 319:1235-1238.

Fargione JE, Plevin RJ, Hill JD. 2010. The Ecological Impact of Biofuels. Annual Review of Ecology, Evolution, and Systematics 41:351-377.

Gallai N, Salles J-M, Settele J, Vaissière BE. 2009. Economic valuation of the vulnerability of world agriculture confronted with pollinator decline. Ecological Economics 68:810-821.

Gardner TA et al. 2007. The cost-effectiveness of biodiversity surveys in tropical forests. Ecology Letters 11:139-150.

Garibaldi LA et al. 2011. Stability of pollination services decreases with isolation from natural areas despite honey bee visits. Ecology Letters 14:1062-1072.

Garibaldi LA et al. 2013. Wild Pollinators Enhance Fruit Set of Crops Regardless of Honey Bee Abundance. Science 339:1608-1611. A

Garibaldi LA et al. 2016. Mutually beneficial pollinator diversity and crop yield outcomes in small and large farms. Science 351:388-391.

Goulson D, Nicholls E, Botias C, Rotheray EL. 2015. Bee declines driven by combined stress from parasites, pesticides, and lack of flowers. Science 347:1255957-1255957.

Greenleaf SS, Williams NM, Winfree R, Kremen C. 2007. Bee foraging ranges and their relationship to body size. Oecologia 153:589-596.

Grixti JC, Wong LT, Cameron SA, Favret C. 2009. Decline of bumble bees (Bombus) in the North American Midwest. Biological Conservation 142:75-84.

Hladik ML, Vandever M, Smalling KL. 2016. Exposure of native bees foraging in an agricultural landscape to current-use pesticides. The Science of the Total Environment 542:469-477.

Howe C, Suich H, Vira B, Mace GM. 2014. Creating win-wins from trade-offs? Ecosystem services for human well-being: A meta-analysis of ecosystem service trade-offs and synergies in the real world. Global Environmental Change 28:263275. Elsevier Ltd.

IPCC. 2014. Climate Change 2014: Synthesis Report. Contribution of Working Groups I, II and III to the Fifth Assessment Report of the Intergovernmental Panel on Climate Change. Pages 1-169 (Pachauri RK, Meyer LA, editors). IPCC, Geneva, Switzerland.

Immerzeel DJ, Verweij PA, van der Hilst F, Faaij APC. 2013. Biodiversity impacts of bioenergy crop production: a state-of-the-art review. GCB Bioenergy 6:183-209. 
Isbell F et al. 2011. High plant diversity is needed to maintain ecosystem services. Nature 477:199-202.

Jetz W, Wilcove DS, Dobson AP. 2007. Projected Impacts of Climate and Land-Use Change on the Global Diversity of Birds. PLOS Biology 5:e157.

Karp DS, Mendenhall CD, Sandí RF, Chaumont N, Ehrlich PR, Hadly EA, Daily GC. 2013. Forest bolsters bird abundance, pest control and coffee yield. Ecology Letters 16:1339-1347.

Kelly D, Ladley JJ, Robertson AW, Anderson SH, Wotton DM, Wiser SK. 2010. Mutualisms with the wreckage of an avifauna: the status of bird pollination and fruitdispersal in New Zealand. New Zealand Journal of Ecology 34:66-85.

Kennedy CM et al. 2013. A global quantitative synthesis of local and landscape effects on wild bee pollinators in agroecosystems. Ecology Letters 16:584-599.

Klatt B, Klaus F, Westphal C, Tscharntke T. 2014. Enhancing crop shelf life with pollination. Agriculture \& Food Security 3:14

Klatt BK, Holzschuh A, Westphal C, Clough Y, Smit I, Pawelzik E, Tscharntke T. 2013. Bee pollination improves crop quality, shelf life and commercial value. Proceedings of the Royal Society B: Biological Sciences 281:20132440-20132440.

Klein A-M, Vaissière BE, Cane JH, Steffan-Dewenter I, Cunningham SA, Kremen C, Tscharntke T. 2007. Importance of pollinators in changing landscapes for world crops. Proceedings of the Royal Society B: Biological Sciences 274:303-313.

Kline KL, Martinelli FS, Mayer AL, Medeiros R, Oliveira COF, Sparovek G, Walter A, Venier LA. 2015a. Bioenergy and Biodiversity: Key Lessons from the Pan American Region. Environmental Management 56:1377-1396.

Kline KL, Martinelli FS, Mayer AL, Medeiros R, Oliveira COF, Sparovek G, Walter A, Venier LA. 2015b. Bioenergy and Biodiversity: Key Lessons from the Pan American Region. Environmental Management 56:1377-1396.

Kremen C, Ostfeld RS. 2005. A call to ecologists: measuring, analyzing, and managing ecosystem services. Frontiers in Ecology and the Environment 3:540-548.

Kronenberg J. 2014. What can the current debate on ecosystem services learn from the past? Lessons from economic ornithology. Geoforum 55:164-177.

Laterra P, Orúe ME, Booman GC. 2012. Spatial complexity and ecosystem services in rural landscapes. "Agriculture, Ecosystems and Environment" 154:56-67.

Lawler JJ, Lewis DJ, Nelson E, Plantinga AJ, Polasky S, Withey JC, Helmers DP, Martinuzzi S, Pennington D, Radeloff VC. 2014. Projected land-use change impacts on ecosystem services in the United States. Proceedings of the National Academy of Sciences of the United States of America 111:7492-7497.

Lebuhn G et al. 2012. Detecting Insect Pollinator Declines on Regional and Global Scales. Conservation Biology 27:113-120.

Lee KV et al. 2015. A national survey of managed honey bee 2013-2014 annual colony losses in the USA. Apidologie 46:292-305.

Lonsdorf E, Kremen C, Ricketts T, Winfree R, Williams N, Greenleaf S. 2009. Modelling pollination services across agricultural landscapes. Annals of Botany 103:1589-1600.

Mace GM, Norris K, Fitter AH. 2012. Biodiversity and ecosystem services: a multilayered relationship. Trends in Ecology \& Evolution 27:19-26. 
Mantyka-Pringle CS, Martin TG, Rhodes JR. 2013. Interactions between climate and habitat loss effects on biodiversity: a systematic review and meta-analysis. Global Change Biology 19:1642-1644.

Meller L, Thuiller W, Pironon S, Barbet-Massin M, Hof A, Cabeza M. 2015. Balance between climate change mitigation benefits and land use impacts of bioenergy: conservation implications for European birds. Global change biology. Bioenergy 7:741-751.

Miller-Struttmann NE, Geib JC, Franklin JD, Kevan PG, Holdo RM, Ebert-May D, Lynn AM, Kettenbach JA, Hedrick E, Galen C. 2015. Functional mismatch in a bumble bee pollination mutualism under climate change. Science 349:1541-1544.

Morales CL, Arbetman MP, Cameron SA, Aizen MA. 2013. Rapid ecological replacement of a native bumble bee by invasive species. Frontiers in Ecology and the Environment 11:529-534.

Newbold T, Scharlemann JPW, Butchart SHM, Sekercioglu CH, Alkemade R, Booth H, Purves DW. 2012. Ecological traits affect the response of tropical forest bird species to land-use intensity. Proceedings of the Royal Society B: Biological Sciences 280:20122131-20122131.

Ollerton J, Winfree R, Tarrant S. 2011. How many flowering plants are pollinated by animals? Oikos 120:321-326.

Polasky S, Nelson E, Pennington D, Johnson KA. 2010. The Impact of Land-Use Change on Ecosystem Services, Biodiversity and Returns to Landowners: A Case Study in the State of Minnesota. Environmental and Resource Economics 48:219-242.

Posner SM, McKenzie E, Ricketts TH. 2016. Policy impacts of ecosystem services knowledge. Proceedings of the National Academy of Sciences of the United States of America 113:1760-1765.

Potts SG, Biesmeijer JC, Kremen C, Neumann P, Schweiger O, Kunin WE. 2010. Global pollinator declines: trends, impacts and drivers. Trends in Ecology \& Evolution 25:345-353.

Repo A, Tuomi M, Liski J. 2010. Indirect carbon dioxide emissions from producing bioenergy from forest harvest residues. GCB Bioenergy 3:107-115.

Ricketts TH et al. 2008. Landscape effects on crop pollination services: are there general patterns? Ecology Letters 11:499-515.

Rundlöf M et al. 2015. Seed coating with a neonicotinoid insecticide negatively affects wild bees. Nature Publishing Group 521:77-80.

Sekercioglu CH. 2012. Bird functional diversity and ecosystem services in tropical forests, agroforests and agricultural areas. Journal of Ornithology 153:153-161.

Sekercioglu Ch, Loarie Sr, Oviedo Brenes F, Ehrlich Pr, Daily GC. 2007. Persistence of Forest Birds in the Costa Rican Agricultural Countryside. Conservation Biology 21:482-494.

Tscharntke T, Sekercioglu CH, Dietsch TV, Sodhi NS, Hoehn P, Tylianakis JM. 2008. Landscape constraints on functional diversity of birds and insects in tropical agroecosystems. Ecology 89:944-951.

Vamosi JC, Knight TM, Steets JA, Mazer SJ, Burd M, Ashman T-L. 2006. Pollination decays in biodiversity hotspots. Proceedings of the National Academy of Sciences 103:956-961. 
Vanbergen AJ, Initiative TIP. 2013. Threats to an ecosystem service: pressures on pollinators. Frontiers in Ecology and the Environment 11:251-259.

Wenny DG, DeVault TL, Johnson MD, Kelly D, H Sekercioglu C, Tomback DF, Whelan CJ. 2011a. The Need to Quantify Ecosystem Services Provided by Birds. The Auk 128:1-14.

Wenny DG, DeVault TL, Johnson MD, Kelly D, H Sekercioglu C, Tomback DF, Whelan CJ. 2011b. The Need to Quantify Ecosystem Services Provided by Birds. The Auk 128:1-14.

Whelan CJ, Sekercioglu CH, Wenny DG. 2015. Why birds matter: from economic ornithology to ecosystem services. Journal of Ornithology 156:227-238.

Whelan CJ, Wenny DG, Marquis RJ. 2008. Ecosystem Services Provided by Birds. Annals of the New York Academy of Sciences 1134:25-60.

Whitehorn PR, O'Connor S, Wackers FL, Goulson D. 2012. Neonicotinoid Pesticide Reduces Bumble Bee Colony Growth and Queen Production. Science 336:351-352.

Williams NM, Crone EE, Roulston TH, Minckley RL, Packer L, Potts SG. 2010. Ecological and life-history traits predict bee species responses to environmental disturbances. Biological Conservation 143:2280-2291.

Winfree R, Bartomeus I, Cariveau DP. 2011. Native Pollinators in Anthropogenic Habitats. dx.doi.org 42:1-22. Annual Reviews.

Winfree R, Williams NM, Dushoff J, Kremen C. 2007. Native bees provide insurance against ongoing honey bee losses. Ecology Letters 10:1105-1113. 


\title{
2. Bird community responses to afforested eucalyptus plantations in the Argentine pampas ${ }^{1}$
}

\begin{abstract}
Land-use change driven by human population growth and economic activity will continue to impact both natural habitats and land currently being used for food, fiber, and fuel production. The effects of this conversion on economically important ecological services will in large part depend on how native biodiversity responds to these changes. We investigated how agriculture-related land use change influences the avian community in northeastern Argentina by examining common agricultural land uses (pasture/annual crops, young and mature large-scale eucalyptus plantations, mixed-use farms with citrus, blueberry and small stands of eucalyptus) and remnant native espinal savannas. In this region, afforested eucalyptus plantations represent a new land-use change from the land cover of pasture with intermixed annual crops that has dominated the region. In this mosaic, we used point counts to assess how avian diversity and community structure differed between land uses. Bird species richness was lowest in older plantations and highest in the espinal savanna, with the other land uses having intermediate richness. Abundance trends followed the same pattern, with low overall abundance in the plantations, intermediate levels for pasture/annual crops, and highest abundance in the espinal. Distinct bird community assemblages were strongly associated with each land use, and between young and mature eucalyptus stands. Birds can be useful indicators for biodiversity as a whole, and the depopulated and depauperate avian community within the eucalyptus plantations will likely lead to reduced provision of many ecosystem services in this region if the spatial extent of plantations continues to expand.
\end{abstract}

\section{Introduction}

It has been estimated that in the next 40 years, the human population will need to grow more food than was produced in the previous 10,000 years (The Economist 2015). In addition, global demand for wood as a raw material is expected to increase each year by between $1.3 \%$ and $1.8 \%$, at least through 2030 (Gardiner and Moore 2014), and total plantation forest coverage worldwide is expected to reach 300 million ha by 2020 (FSC 2012). One of the greatest challenges facing biodiversity conservation in an era of rapid human population growth is understanding how land-use change related to commodity food and fiber production will influence species composition and persistence (Vitousek et al. 1997, Zimmer 2010). The 2005 Millennium Ecosystem Assessment highlighted understanding this relationship as a priority, and it is repeatedly identified as a key to retaining biodiversity and associated ecological services in sustainable production landscapes of the future (Pascual and Perrings 2007, Perfecto and Vendermeer 2010, Tomich et al. 2011).

Biodiversity supports many ecosystem functions, allowing the delivery of more than 25 cultural, provisioning, regulating, and supporting ecosystem services to humans (MEA 2005; Balvanera et al. 2006; Flynn et al. 2009; Thompson et al. 2009; Brockerhoff et al. 2013; Whelan et al. 2015). Among vertebrates, birds contribute to a number of essential ecosystem functions as a result of their taxonomic and niche diversity (Sekercioglu 2006). For example, birds provide essential and economically valuable ecosystem services such as pest control, seed dispersal, and pollination, in addition to the recreation value they provide to humans (for a full list see Sekercioglu 2006 and Whelan et al. 2015). In agricultural systems, birds aid farmers by consuming pest species, and, indeed, "economic ornithology" in the early 1900s was one of the

\footnotetext{
${ }^{1}$ Previously published, copy-righted material. See Phifer, C., Knowlton, J., Webster, C., Flaspohler, D. Licata, J. 2016. Bird community responses to afforested eucalyptus plantations in the Argentine pampas. Biodiversity and Conservation 26(13) 3073-3101
} 
first attempts to directly associate biodiversity with tangible benefits to human agriculture and wellbeing (Kronenberg 2014).

The pampas, once one of the largest temperate grassland in South America, spans an area of more than 52 million ha (Solbrig and Viglizzo 1999). Since European colonization, much of the pampas grassland and savanna of northern Argentina has been converted to agriculture, including row crops and cattle pasture, with documented changes to the avian community (Goijman and Zaccagnini 2008, Giacomo et al 2010; Cerezo et al. 2011; Gavier-Pizarro et al. 2012; Codesido et al. 2011, 2013). This region was greatly modified by the introduction of modern-day agriculture and livestock grazing and it is now one of the most important areas for beef and grain production in the world (Miñarro and Bilenca 2008). Today, only $10 \%$ of the region's native grassland and savanna remains, with less than 1\% protected (Henwood 2010; Medan et al. 2011); worldwide, remaining native grasslands and savannas continue to be targeted for conservation because of their rarity and continued conversion to agriculture and pasture (Henwood 2010; Azpiroz et al. 2012). The original pampas ecosystem contained espinal savanna, a habitat composed of short, shrubby native trees, mostly Prosopis and Acacia species, with a diverse community of associated bird species (Fig. 2; Bucher et al. 2001, Lewis et al. 2009). As with the region's grasslands, most of the espinal ecosystem has been transformed by agriculture and grazing with remaining espinal savannas scattered in small remnants within a vast agricultural matrix (Lewis et al. 2009).

In Entre Ríos province of northeastern Argentina, the already transformed pampas is now undergoing another potentially transformative land-use conversion: afforestation through planting of eucalyptus for pulp, building materials and wood pellets for biomass energy production (Baldi and Paruelo 2008; FAO 2010; Azpiroz et al. 2012). Eucalyptus plantations are expanding in Argentina partly as a result of policies that promote afforestation, and the Entre Ríos region is experiencing some of the fastest growth of this kind with unknown impacts on avian communities. Eucalyptus (mostly Eucalyptus grandis) is the dominant plantation tree in the region, though pine (Pinus sp.) is also present (INTA 2009). Most eucalyptus plantations are large-scale monocultures covering hundreds of hectares with even-density, even-aged stands and little understory vegetation. The spatial scale of these plantations closely mirrors the land ownership in the region, where individual owners often hold thousands of hectares of land. In some areas, however, average land holdings are smaller, with mixed-use farms of 10-50 ha with cattle, citrus and blueberries and less-intensively managed eucalyptus stands of 1-10 ha intermixed. This dichotomous landscape patterning also reflects a common global trend, for although some anthropogenic land-use change occurs on vast spatial scales, much land cover change for the foreseeable future will continue to involve spatially small mosaics of different cover types (FSC 2012). Birds may respond differently to not only land use change, but the spatial scale of these afforested plantations and eucalyptus stands.

For bird species adapted to native grasslands or diverse native forests, conversion to structurally and compositionally simplified commodity production of woody or agricultural species frequently leads to a loss or degradation of habitat quality (Fuller 2012), often resulting in replacement of one assemblage of birds by another with few shared species (Dias et al. 2013). Birds are highly vagile and thus many species have the ability to quickly monitor and respond to dynamic changes in land cover related to both management by humans and natural succession and aging of forests (Da Silva 1996), grasslands (Grant et al. 2004), and even agricultural lands (Vickery et al. 2001). The diversity of bird species and the dynamic nature of both natural and anthropogenic land-cover change have meant that generalities regarding how birds as a group are affected by land-use change, and particularly intensification of land use, have been difficult to identify (Warner 1994). Because birds can have a powerful influence on some ecosystem services (Wenny et al. 2011), changes in species richness and composition have the potential to greatly alter the functioning of such services (Kellerman et al. 2008; Flynn et al. 2009). Moreover, birds are one of the most cost-effective bioindicators for measuring the effects land-use change on broader biodiversity, which in turn, support additional ecosystem services (Gardner et al. 2007, 2008).

Recent scholarly debate regarding the effects of forest plantations on ecosystem services (e.g., Paquette and Messier 2010; Brockerhoff et al. 2013) highlight the importance of considering the landscape context of plantations and alternative land covers (Brockerhoff et al. 2008). For instance, afforestation of former 
grasslands involves a major structural change in the vegetation, and is usually detrimental for grassland biodiversity but could potentially benefit forest-dependent species (Brockerhoff et al. 2008). As an example, in South Africa the sharp contrast between the native grasslands and afforested plantations resulted in a negative impact of grassland bird species, even when plantations were small compared to the surrounding countryside (Allan et al. 1996). In forested areas, however, forest bird species may use exotic plantations, and such plantations may be preferable than farmland or other cleared landscapes (Lindenmayer et al. 2002; Deconchat et al. 2009). When evaluating the effects of expanding plantation forestry, another important consideration is the most likely alternative or previous land uses (Brockerhoff et al. 2008). Although it can be interesting to compare tree plantations to native primary forest or native grassland, in many parts of the world, there is no realistic near term possibility of expanding the coverage of native forest or restoring converted grasslands, even if tree plantations were removed. Instead, where tree plantations are proposed or expanding, it is often more useful to compare biodiversity and ecosystem services provided by tree plantations to the types of land uses that would occur in their absence, such as farming or livestock grazing.

We examined one such landscape mosaic in Entre Ríos province, Argentina, where the traditional land use (pasture and annual crops) is rapidly being replaced by a novel land use (eucalyptus plantations), and how these land uses affect the avian communities and their associated ecological services. In this transforming landscape, we compared four common land uses in the region: 1) large cattle pastures (>100 ha) that rotate to annual crops, the dominant land use; 2) large-scale eucalyptus plantations (>100 ha);3) mixed-use farms with citrus and blueberry fields, pastures and small eucalyptus stands ( $<10 \mathrm{ha})$; and 4$)$ espinal savanna remnants. We also considered how eucalyptus stand age might impact avian diversity and whether a threshold existed for birds between young stands without canopy closure and older stands with closed canopies. We predicted that bird diversity would be greatest in the native espinal savanna and lowest in the large eucalyptus plantations, with intermediate levels of diversity in the pastures/annual crops and mixeduse farms, because the plantations are the most structurally different from the original mosaic grasslands and savanna that characterized the Argentine pampas for millennia prior to European arrival. Recognizing the rapid structural and microclimatic changes that accompany the growth of eucalyptus (de Souza 2010), we also examined how plantation age impacts the bird community by comparing bird diversity in older closed-canopy (10-15 years) and young ( $<4$ years) open canopy eucalyptus plantations. We expected that young stands would show greater bird diversity than mature stands, again due to the greater structural dissimilarity between mature plantations and pre-European settlement grasslands. Finally, we tested for the presence and extent of edge effects produced by large-scale eucalyptus plantations by censusing birds along $1 \mathrm{~km}$ transects centered on the boundary between plantations and ungrazed grasslands. Because other studies have found that many open habitat birds avoid wooded boundaries (e.g., Coppedge et al. 2004; Fletcher 2005), we predicted that bird diversity would increase with increasing distance from the plantation.

\section{Methods}

\section{Site description}

We conducted our work in the Entre Ríos province of Argentina, near the city of Concordia $\left(31^{\circ} 24^{\prime} \mathrm{S} 58^{\circ} 2^{\prime} \mathrm{W}\right)$. Our sites are located within the Mesopotamia region of the pampas, characterized by once extensive grasslands (Quattrocchio et al. 2008) that have been converted to pasture for grazing and fields for row crops. Climate in this region varies from a daily mean temperature of $12.6 \mathrm{C}$ during the austral winter to $25.3 \mathrm{C}$ during the summer, and more than $1,300 \mathrm{~mm}$ of rainfall annually (INTA 2015). This region contains hundreds of native grass and other plant species and approximately 300 breeding bird species (Krapovickas and Di Giacoma 1998), 60 of which are grassland specialists (Miñarro and Bilenca 2008), and nearly one hundred mammal species (Miñarro and Bilenca 2008). The province is bordered by the Río Uruguay to the east and the Río Paraná to the west, with low rolling terrain and loessic or clay sediments (Miñarro and Bilenca 2008). This region is now mostly composed of croplands (26.5\%), rangeland (45.2\%), managed pasture (5.5\%) and afforested plantations (13.6\%) (Viglizzo et al. 2006). 
Large-scale eucalyptus plantation management generally consists of even-age stands with trees planted $4 \mathrm{x}$ $2.5 \mathrm{~m}$ apart with stocking densities averaging 1000 trees/ha (Carpineti et al. 1995). Planted seedlings are generally sprayed with insecticide to limit herbivory from insects and pruned and thinned as they grow. Trees are harvested at 10-15 years depending on site conditions and allowed to resprout from the stump post harvest (Carpineti et al. 1995). Young eucalyptus stands usually contain grass and herbaceous plants, with the trees appearing shrub-like while older stands eventually produce a uniformly darker environment with almost no understory herbaceous or shrub vegetation layer. Generally, older eucalyptus trees have little branching below the canopy with compact canopy crowns at the top and almost no epiphytes, mosses or other micro-habitat features along the trunk.

\section{Experimental design}

We censused the avian communities in four common land uses throughout Entre Ríos province: 1) pastures used for livestock grazing and rotational annual crops near the town of General Campos; 2) large-scale eucalyptus plantations (>100 ha), adjacent to the Ubajay township; 3) small mixed-use farms with citrus, blueberry, pastures and small-scale eucalyptus stands ( $<10 \mathrm{ha})$ in the town of La Criolla; and 4) espinal savanna, outside of the town of Federal (Fig.1 and Fig. 2). Land cover was identified using 2013 satellite imagery, GIS software, and extensive ground-truthing. After identifying suitable areas, we contacted landowners and secured permission to work at these sites. Due to the landownership and land use patterns characterized by one exclusive land use at a time, it was not possible to use a block design. Instead, within each of our four focal land uses, we delineated four $300 \mathrm{~m}^{2}$ plots at least $1 \mathrm{~km}$ from any other, at least 500 $\mathrm{m}$ from paved roads or rivers, and composed of $\geq 75 \%$ of the target land use type. Within the large-scale eucalyptus plantations, we further demarcated three additional $300 \mathrm{~m}^{2}$ plots of young, even-aged eucalyptus stands ( $\leq 4$ years old) that had not achieved canopy closure and featured grass and herbaceous layers. The majority of the plantations we surveyed featured only mature stands nearing harvest age, and it was impossible to find young stands that were $1 \mathrm{~km}$ apart from each other or mature stands, but we surveyed these younger stands on separate days to temporally separate them.

\section{Field methods}

We conducted two rounds of point counts in each of the land use types and the younger eucalyptus stands. Weather prevented resampling at one espinal replicate during the second round, reducing our espinal sampling effort to 70 total points. One point in the mixed-use farms was excluded due to harvesting at the time of observation. For all other land uses, we completed 80 points counts, for a study-wide total of 459 points. In each $300 \mathrm{~m}^{2}$ land use replicate, we randomly identified 10 point count locations that were $\geq 200 \mathrm{~m}$ from one another and $>50 \mathrm{~m}$ from a cover type edge. Within the mixed-use farms, we used a stratified random sampling design to ensure coverage of all land use types in proportion to their abundance, including the smaller eucalyptus stands. We also tested for possible edge effects from large-scale eucalyptus plantations on bird communities by conducting 10 point counts at $100 \mathrm{~m}$ intervals along three $1000 \mathrm{~m}$ transects centered on the border of a large-scale eucalyptus plantation and adjacent ungrazed grasslands of El Palmar National Park (Fig. 6). Five of the points were in the mature eucalyptus and five were in the grasslands, and transects were $\geq 500 \mathrm{~m}$ from one another. For each land use type and transect, one of three observers (who trained together for one month prior to beginning sampling) completed 8minute $25 \mathrm{~m}$ fixed-radius point counts at each point and noted all birds seen or heard within $25 \mathrm{~m}$, excluding those flying overhead. We selected this conservative detection distance because, based upon preliminary experience, detections rates were variable across habitats and we wanted to be able to compare land uses without the influence of detection bias. Because we visited each site twice, it is unlikely that breeding birds went undetected during our counts. Counts were conducted from 1-19 September and 3-27 November 2014 during the breeding season for most local birds. The point counts began near sunrise and were completed within 4 hours, allowing two observers to complete two replicates in one day. All counts were conducted in clear, mild weather without rain, fog or excessive wind. 


\section{Data analysis}

To examine how the different land-use types and eucalyptus stand age influenced avian species, we calculated species diversity and community composition. Species richness $(S)$, Shannon's Diversity Index $(H)$, Shannon's Evenness $(E)$, and Simpson's Diversity Index $(D)$ were calculated using the Row and Column analysis feature in PC-Ord 6.08 (McCune and Grace 2002) for each landscape replicate. Results were averaged and tested for significance using Kruskal-Wallis and post-hoc comparisons. We then used PC-Ord to describe bird community composition using the Nonmetric Multidimensional Scaling (NMDS) ordination technique. Land use was included as a categorical variable in the environmental matrix. For this analysis, young and old eucalyptus stands were coded as separate land uses. We used the maximum abundance for each species observed for each land use and ran the ordination with autopilot defaults, the "deep and thorough" option, and Sørenson (Bray-Curtis) distance with 250 iterations of real data and 250 runs of randomized data (McCune and Grace 2002). To identify species strongly associated with each landuse type, we used PC-Ord's Species Indicator Analysis function, which calculates an Indicator Value (IV) from 0 to 100 for each species based on abundance and frequency, with higher values for species with strong land-use fidelity (Dufrene and Legendre 1997; McCune and Grace 2002). The IVs were then tested with a Monte Carlo test for significance using an $\alpha$-value of 0.05 . Finally, we evaluated potential edge effects on bird communities using non-linear regression as implemented in SigmaPlot 13 (SigmaPlot 2015), with distance from plantation edge as our independent factor and bird species richness and abundance as our dependent factors. We chose non-linear regression because visual inspection of the data suggested a pronounced sigmoidal tendency.

To better understand potential ecological services provided by birds associated with different land uses, we classified birds by diet guilds. Given the limited availability of detailed locally relevant diet information for each species, we used broad diet guilds (carnivore, omnivore, insectivore, nectivore, granivore, or frugivore) based upon the Handbook of the Birds of the World online database (del Hoyo et al. 2014). We evaluated differences in bird abundance by diet with a non-parametric Kruskal-Wallis test since our data failed to meet ANOVA assumptions (SigmaPlot 2015).

\section{Results}

From both rounds of point counts across all land uses and line transects, we detected 107 bird species and 2,134 total individuals (Appendix A). We recorded approximately 35\% of the estimated 300 birds in this region of Argentina (Krapovickas and Di Giacoma 1998) and approximately 11\% of the 979 confirmed species in the nation of Argentina (Narosky and Yzurieta 2010). Species richness and abundance varied greatly between land use types (Table 1; Fig. 3 and 4), with fewer species detected in older eucalyptus stands compared with all other dominant land uses in the region, including young eucalyptus stands, which contained nearly twice as many birds species as older stands ( $p$-values < 0.001). Pasture and annual croplands, the dominant land uses in the region for at least three centuries, had similar numbers of species and individuals compared to smaller scale mixed-use farms. In contrast, the espinal savanna had the highest levels of both species richness and individual abundances of all land uses, with 27 species found only there, and never in the other habitats surveyed.

In addition to differences in species richness and abundance, each land use was characterized by a distinct avian community (Fig. 5). The NMDS ordination for the bird community assemblages resulted in a twodimensional solution with a final stress of 11.98 following 62 iterations, a reliable and interpretable score (McCune and Grace 2002). The final solution cumulatively explained $85 \%$ of the variation in community composition. Although pasture and annual crops and mixed-use farms had similar abundance and richness estimates, the bird communities in each were distinctly different (Fig. 3 and 4). Bird species associated with pasture and annual crops, an area characterized by low stature vegetation, were very different from the mixed-use farms, where most bird species were habitat generalists with shared affinities for other land habitats. The relatively depauperate bird community associated with the older eucalyptus stands was distinct from the historically dominant pasture and annual crop landscape. Young eucalyptus stands 
contained an avian community that resolved between pasture/annual crops and mature eucalyptus stands. The remnant espinal landscape had the highest bird species richness and a highly distinct bird community with many species with high site fidelity.

The species indicator analysis identified 23 species with significant IVs, indicating strong affinities with particular land use types (Table 4). The espinal contained the most species with statistically significant IVs (15 species). This was followed by pasture/annual crop that had 5 significant indicator species. The remaining significant indicator species were associated with mix-use farms. No significant indicator species were found for old or young eucalyptus stands.

The boundary between any age eucalyptus and unmanaged grassland and savannas of El Palmar National Park represented a dramatic change in bird species richness and abundance ( $p$-value < 0.001; Fig.7). Within the plantations, we detected 11 species and 59 individuals; in contrast the adjacent grassland yielded 48 species and 340 individuals. Among non-linear curve families available in Sigma Plot 13, a three-parameter sigmoidal curve model for both abundance and richness provided the best representation of the relationship between plantation edge and species richness and abundance, respectively. The transects within the plantation were universally low in bird diversity, while the grassland transects showed a strong sigmoidal pattern of increased abundance and species richness beyond the plantation edge and continuing into the ungrazed grasslands (Fig.7). The sigmoidal pattern suggests a localized effect of low bird species richness and abundance within the plantation, effects that do not extend far beyond the edges of the eucalyptus plantation.

Bird abundance by diet guild varied by land use type (Fig.8). Within mature eucalyptus stands there was no significant difference in diet guilds, but young eucalyptus stands contained more omnivorous birds ( $p$-value $=0.037)$. Pasture/annual crops supported near equal numbers of granivores and insectivores, and far fewer carnivores or omnivores ( $p$-value $=0.005$ ). Mixed-use farms had a similar trend for granivores and insectivores as well as omnivores, although there were fewer frugivores and carnivores ( $p$-value $<0.001)$. As with species diversity measures, espinal savanna supported high levels of diet guild diversity ( $p$-value $=$ 0.002). Across all land uses the mean relative abundance of species also varied (Fig. 9). We found the majority of carnivores (i.e. raptors) within young and mature eucalyptus plantations compared to other land uses, accounting for more than 50\% of all carnivores in the study area. Pasture/annual crops contained both insectivores and granivores in near equal proportion. Mixed-use farms had a diverse group of dietary guilds as well as high abundances of granivores and insectivores. Insectivores were the most common dietary guild in the espinal savanna, accounting for $50 \%$ of all the insectivores birds surveyed. The espinal also contained high abundances of granivores, and was the only landscape to contain nectivorous hummingbirds. Frugivores were present in mixed-use farms and the espinal savanna, but were absent from the plantations and grasslands.

\section{Discussion}

\section{Implications of expanding afforestation on avian communities and ecosystem services}

In the agricultural mosaic of the Argentine pampas, land available for strict preservation is very limited, suggesting that there is a need to understand how this working landscape can be managed to provide benefits for both humans and biodiversity. We found that in this region, new and expanding large-scale monocultures of eucalyptus are associated with a sharp reduction in both bird abundance and diversity, even when compared with other relatively intensive land uses like cattle grazing and annual crops. The continuing expansion of eucalyptus plantations, particularly large-scale plantations, will likely result in the simplification and loss of avian biodiversity and their associated ecosystem services. Pest control, seed dispersal and pollination - three important ecological and economic ecosystem services, especially in an agriculturally dominant region such as the Entre Ríos province-will likely be impacted. 
Other studies in the region comparing bird communities in eucalyptus plantations to native vegetation have also found lower biodiversity in plantations, especially when plantations contrasted structurally with the surrounding area's vegetation (Dias et al. 2013; Calviño-Cancela 2013). In our study, 16 of the 28 total species detected in large-scale eucalyptus plantations were detected only once, suggesting that few individuals of most species make regular use of the eucalyptus plantations. The four most common species we detected in the large-scale plantations were the ubiquitous Rufous-collared Sparrow (Zonotrichia capensis), followed by White-crested Tyrannulet (Serpophaga subcristata), Picazuro Pigeon (Patagioenas picazuro) and Roadside Hawk (Rupornis magnirostris), together accounting for more than $75 \%$ of all birds recorded within the plantations. Rufous-collared sparrows were commonly seen in flocks near the ground searching for seeds and insects, and White-crested Tyrannulets were regularly encountered near plantation edges hawking for insects from branches near the canopy. Both species are generalists and are commonly observed near human habitation and in altered landscapes (Bellocq et al. 2011; Leveau and Leveau 2012). Among raptors, Roadside Hawks are opportunistic consumers and habitat generalists, and may benefit from the availability of perches and roost sites provided by eucalyptus in a region where trees are rare. Eucalyptus has been linked to the expansion of other birds of prey, notably Swainson's Hawks (Buteo swainsoni), likely for these same reasons (Sarasola and Negro 2006). We also detected two other species of raptor using the eucalyptus as perches; Aplomado Falcon (Falco femoralis), a species usually associated with grasslands, and Chimango Caracara (Milvago chimango), a generalist carnivore and scavenger. These raptors were regularly seen perched in the high canopy, scanning adjacent landscapes for prey.

Within the large-scale eucalyptus plantations, younger stands that had not achieved canopy closure had nearly twice as many bird species and almost three times as many individuals as mature stands, though the two eucalyptus age classes shared eight common species. Similar patterns were found in afforested eucalyptus plantations in Uruguay, with some grassland species detected within young stands, likely because of the presence of taller, ungrazed grass (Dias et al. 2013). Structurally, young eucalyptus are more similar to the pastures/annual crop landscapes and mixed-use farms than the taller, closed-canopy mature eucalyptus stands that have little or no grass or understory and limited micro-habitat features. Interestingly, we identified three species of grassland specialists within the younger stands, including the near-threatened Greater Rhea (Rhea americana) (BirdLife 2012a). In addition, based on our incidental observations, some bird species appear to be able to utilize these younger stands for nesting. In the young stands we observed one Greater Rhea nest with more than 20 eggs, and the Grassland Sparrows (Ammodramus humeralis) were responsive to audio playback, suggesting they were defending established breeding territories.

We found that, in contrast to the large-scale plantations, small-scale eucalyptus stands within mixed-use farms supported a relatively high level of bird species richness and abundance. Although we lacked sufficient replication to test this statistically, within the smaller eucalyptus plantations, which were all older stands, we detected 26 species of birds, twice the number found in the older large plantation stands, suggesting that small stands of old eucalyptus may be more useful as bird habitat than large stands of old eucalyptus. This observation may be a result of plantation size or the less intensive management we observed in small-scale plantations (e.g., less pruning, weeding and thinning). For example, anecdotal evidence suggests these stands contained more understory herbaceous plants and shrubs, and had greater structural diversity; potentially providing better habitat than more intensively managed, manicured plantations (Marsden et al. 2001). These results contrast with related work in South Africa where even small amounts of afforested plantations negatively impacted bird communities (Allan et al. 1996), perhaps because the mixed-use farms featured more generalist species with greater capacity to adapt to land-use changes. Including the other bird species, we recorded in the citrus, blueberry and surrounding pasture of the mixed-use plots, 44 species were detected in the small ownership landscape. These mixed-use farms had 18 species of insectivore, accounting for $26 \%$ of the total bird abundance, suggesting a strong potential for avian-delivered pest management. This small ownership landscape resembles some agro-forestry based production systems and appears to support greater biodiversity and ecosystem service provisioning than the current dominant large-scale monocultures of even-aged dense stands. Other agro-forestry systems in the tropics have also been shown to support greater bird diversity than monocultures, delivering tangible pestcontrol services to area farms (Van Bael et al. 2008, Karp et al. 2014). 
Interestingly, in some parts of the world where tree plantations are more similar to the surrounding area vegetation, plantations can support comparable levels of biodiversity to native forest, as in Patagonia in southern Argentina where exotic pine plantations provided habitat for many native forest species (Lantschner et al. 2008). Similarly, in Brazil plantations of Araucaria angustifolia, a native tree, maintained more than $90 \%$ of the bird species of the nearby native forests (Volpato et al. 2010). In the case of afforested plantations that replaced pasture and ranchland, we found a very different relationship. The area's pasture and croplands supported a diverse and distinct bird community with 41 species, three times as many birds as in the mature eucalyptus plantations. Most of the bird species associated with the pastureland were common generalists that appear to be tolerant of cattle grazing, including eight species that are noted grassland specialists, often in the taller parts of the fields. Our results are consistent with other work where plantations replace grasslands, steepe and open-area habitats, which effect a shift in avian communities and decline in bird diversity (Allan et al.1997; Lantschner et al. 2008).

Although the region's current dominant land use remains pasture and annual crops, historically the espinal was more prevalent on the landscape (Lewis et al 2006). The espinal savanna contained more than $40 \%$ of all the bird species detected in this study, including many species undetected in other habitats. The espinal's shrubby trees provide habitat for many woodland associated species. Anecdotally, we noted that the trees of the espinal have many cavities and crevices, lichens and epiphytes, all elements of structural diversity that are absent in the smooth-barked and uniform eucalyptus plantations. For instance, three species of hummingbirds were often seen foraging on epiphytic flowers growing on the espinal trees, a resource absent within the plantations.

In most of the landscapes we surveyed, we encountered common species, but several rare species and species of concern were also counted. We detected several Dark-throated Seedeaters (Sporophila ruficollis) in the pastureland, a species of concern (Birdlife 2012b), and considered to be declining because of increasing agricultural intensity and forest plantations in the region (Filloy and Bellocq 2006; Birdlife 2012). The Greater Rhea, also a species of concern, was regularly observed near the plantations, though generally, in the younger stands. If afforestation in the region continues, however, at some point the avian community associated with pasture/annual crops may drift towards the depopulated community found in large-scale eucalyptus plantations. In addition to the birds detected during the point counts, we twice encountered a male and female yellow cardinal (Gubernatrix cristata) in the espinal savanna, an endangered species on the IUCN's Red List (BirdLife International 2013). The presence of this species, listed as rare in Argentina (BirdLife International 2013), underscores the conservation value of this habitat and warrants further study.

\section{Edge effects of afforestation on pampas bird communities}

Adjoining habitats, whether natural or resulting from anthropogenic activities, can create species interactions and novel patterns of biodiversity that can both enhance and harm individuals living in such zones (Lay 1938, Gates and Gysel 1978, Fagan et al. 1999, Flaspohler et al. 2001a, 2001b). The abruptness of the change in plant and animal communities is sometimes termed the "hardness" of the edge, and, in this study, mature eucalyptus plantations adjacent to grassland is clearly a hard edge based on both plant species structure and composition. Not surprisingly, we found that the greatly simplified vegetation community of the plantations was associated with a similarly simplified avifauna. Our results are consistent with related work that found mature eucalyptus stand edges were "hard" when contrasted with relatively more open areas, possibly the result of the visual obstruction caused by the uniformly tall trees and darker understory (Reino et al. 2009). Interestingly, bird species richness in the grassland immediately next to mature eucalyptus remains as high or higher than areas farther from the plantations and deeper in the "pure" grassland habitats. This is not simply a result of overlap of two distinct bird communities, one associated with eucalyptus and another with the open grasslands. Rather, it suggests that for birds using the more natural native open habitats in this region, the mature eucalyptus plantations do not have a repellant influence beyond their boundary. It will be important to evaluate the influence of proximity to this edge on bird survival and reproduction and the dynamics of the boundary during the harvest, growth, and rapid 
maturation of the eucalyptus plantations. Recent studies have found that in some landscapes, hard edges are associated with higher bird nest predation rates compared to soft edges with lower contrast between adjoining vegetation (Schneider et al. 2012).

\section{Management recommendations and future research needs}

In the foreseeable future, growing demand for timber and pulp, and government policies that favor conversion to eucalyptus will continue to drive expansion of this species in the Entre Ríos province of Argentina, and indeed in many other parts of South America (Jobbagy et al. 2012). In order to improve biodiversity conservation and mitigating potential ecosystem service losses, we recommend evaluating the effectiveness of both stand-level and landscape level conservation strategies, since birds perceive and respond to both scales (Moreira et al. 2005). Within plantations, we recommend integrating greater habitat heterogeneity within and adjacent to plantation stands as well as managing landscapes with a mix of young and mature eucalyptus stands. We found that younger stands of eucalyptus supported more species and in greater abundance, as well as a community that is more similar to both the mixed-use farms and older eucalyptus stands. Plantation managers should try to balance the coverage of young and older stands to mitigate some of the biodiversity loss within aging stands of eucalyptus. Biological legacies such as the yatay palms (Butia yatay), which are endemic to the region, should be left standing whenever possible, and we recommend studying the feasibility of habitat enhancements such as corridors and gaps to facilitate understory vegetation and a light environment more similar to the pastures and grasslands, which has been demonstrated to improve avian biodiversity in afforested eucalyptus plantations in Brazil and pine plantations in Spain (Diaz et al. 1998, Barrientos 2010; Millan et al. 2015). Related work in pine plantations in Chile, for instance, found that the presence of native understory vegetation resulted in increases in bird biodiversity and ecosystem services, particularly pest management by insectivore birds (Poch and Simonetti 2013). In this system, the understory vegetation is thought to "soften" the barriers between the plantations and the surrounding matrix, facilitating the movement of individuals (Tomasevic and Estades 2008).

We also recommend studying the adoption of silvopastoral systems with reduced eucalyptus density and complementary cattle grazing. A "win-win" situation was found in the Argentine Chaco forests with intermediate cattle density and forest tree density that conserved much of the area's avian diversity while still being profitable (Mastrangelo and Gavin 2012). The espinal system we studied, for instance, is partially grazed by cattle, and yet still features a rich avian community. Beyond the plantation, our results on possible edge effects suggest that bird diversity quickly rebounds, and managers may designate some land reserves for birds and other species, adopting a "land-sparing" strategy for biodiversity conservation in this intensely used landscape.

Our work is the first to consider how avian communities change in response to afforested plantations in this region. Eucalyptus plantations are widespread and expanding in the global southern hemisphere. We compared land uses broadly, but further studies should consider specific habitat measures that may influence stand-level species occupancy. Our research also did not consider within season variation between migrant and resident birds and how land use influences these intra-season communities, which may respond to land use differently. Additional work is also needed to determine the demographic responses of birds to these novel afforested plantations. For example, related work in the pampas found low rates of bird reproductive success in heavily modified agricultural areas that are similar to the pastures and annual crops that surround many of the large-scale eucalyptus plantations (Pretelli et al. 2015). Finally, future research should investigate the extent to which these afforested eucalyptus stands act as barriers to the movements and dispersal patterns of grassland birds. In other systems, monocultures of even-aged stands of trees that were structurally similar to the surrounding forest were demonstrated to impact forest birds' movement patterns (Villard and Haché 2012), and we expect that the contrasting structural and light environment of mature eucalyptus plantations could deter grassland bird movements. 


\section{Conclusions}

We considered the potential impacts of land-use change associated with afforested large-scale eucalyptus plantations on avian biodiversity. In Entre Ríos, the expansion of the current model of large-scale, eucalyptus monocultures will likely result in simplification of avian communities and reduced ecosystem benefits provided by these birds. Other land uses in the region, including mixed-use farms, traditional pasture/annual crops and native espinal savanna, supported higher levels of avian diversity with distinct communities. Land-use change also impact dietary guilds of birds, which may influence delivery of birddependent ecosystem services. Other ecosystem services, which are often but not always related to biodiversity, including carbon sequestration, nutrient cycling, timber production, water regulation, and recreation, should be considered when evaluating the cost of land-use changes associated with afforested eucalyptus plantations (Polasky et al. 2010; Goldstein et al. 2012; Carreño et al 2012).

\section{Acknowledgements}

We are thankful for the support of the researchers, extension agents and staff of the Instituto Nacional de Tecnología Agropecuaria Concordia, particularly P. Cavigliasso and L. Roman, without which, this research would not be possible. The authors are deeply indebted to S. Oliviera for his expertise in avian ecology and identification of pampas birds. We are especially thankful to many landowners of La Criolla, General Campos and Federal and companies Comercio y Desarrollo S.A. and Com BeyGa Humaitá S.A. who granted us access to their lands to conduct this research. We also thank El Palmar National Park that permitted us to complete bird surveys within the park. This research was supported by the National Science Foundation Partnerships in International Research and Education grant (No.1243444). Our thanks to the anonymous reviewers who greatly improved earlier drafts of this manuscript.

\section{Literature cited}

Allan DG, Harrison JA, Navarro R, van Wilgen BW, Thompson MW (1997) The impact of commercial afforestation on bird populations in Mpumalanga Province, South Africa-insights from bird-atlas data. Biol Conserv 79(2):173-85

Azpiroz AB, Isacch JP, Dias RA, DiGiacomo AS, Fontana CS, Palarea CM (2012) Ecology and conservation of grassland birds in southeastern South America: a review. J Field Ornitho 83(3):217-246

Baldi G, Paruelo JM (2008) Land-use and land cover dynamics in South American temperate grasslands. Ecol Soc 13(2):6

Balvanera P, Pfisterer AB, Buchmann, N, He JS, Nakashizuka T, Raffaelli D, Schmid B (2006). Quantifying the evidence for biodiversity effects on ecosystem functioning and services. Ecol Lett 9(10):1146-1156

Barrientos R (2010) Retention of native vegetation within the plantation matrix improves its conservation value for a generalist woodpecker. Forest Ecol Manag 260(5):595-602

Bellocq MI, Filloy J, Zurita GA, Apellaniz, MF (2011). Responses in the abundance of generalist birds to environmental gradients: the rufous-collared sparrow (Zonotrichia capensis) in the southern Neotropics. Ecoscience:18(4)354-362

BirdLife International (2012a) Rhea americana. The IUCN Red List of Threatened Species 2012. http://www.iucnredlist.org/details/22678073/0. Accessed on 15 April 2016. 
BirdLife International (2012b) Sporophila ruficollis. The IUCN Red List of Threatened Species 2012. http://www.iucnredlist.org/details/22723484/0. Accessed on 08 September 2015

BirdLife International (2013) Gubernatrix cristata. The IUCN Red List of Threatened Species 2013. http://www.iucnredlist.org/details/22721578/0. Accessed on 06 June 2015

Bibby CJ, Burgess ND, Hill DA, Mustoe S (2002) Bird Census Techniques 2nd Edition. Academic Press, London

Brockerhoff EG, Jactel H, Parrotta JA, Quine CP, Sayer J (2008) Plantation forests and biodiversity: oxymoron or opportunity? Biodivers Conserv 17:925-951

Brockerhoff EG, Jactel H, Parrotta JA, Ferraz SFV (2013) Role of eucalypt and other planted forests in biodiversity conservation and the provision of biodiversity-related ecosystem services. Forest Ecol Manag 301: 43-50

Bucher EH, Costa Gorriz B, Leynaud G (2001). Bird diversity and forest fragmentation in the semiarid espinal woodland of Córdoba, Argentina. Bol. Acad. Nac. Ciencias, Córdoba 66:117-124

Calviño-Cancela M (2013) Effectiveness of eucalypt plantations as a surrogate habitat for birds. Forest Ecol Manag 310: 692-699

Carpineti LA.; Dallatea F, Glade JE; Marco MA (eds.) (1995) Manual para productores de eucaliptos de la Mesopotamia Argentina. Instituto Nacional de Tecnología Agropecuaria, Estación Experimental Agropecuaria, Concordia. http://inta.gob.ar/documentos/manual-para-productores-deeucaliptos-de-la-mesopotamia-argentina. Accessed 3 Jan. 2016

Carreño L, Frank FC, Viglizzo EF (2012) Tradeoffs between economic and ecosystem services in Argentina during 50 years of land-use change. Agric Ecosyst Environ 154: 68-77

Cerezo A, Conde MC, Poggio SL (2011) Pasture area and landscape heterogeneity are key determinants of bird diversity in intensively managed farmland. Biodivers Conserv 20(12):2649-2667

Codesido M, González-Fischer C, Bilenca D (2011) Distributional changes of landbird species in agroecosystems of central Argentina. Condor 113(2):266-273

Codesido M, González-Fischer CM, Bilenca DN (2013) Landbird Assemblages in Different Agricultural Landscapes: A Case Study in the Pampas of Central Argentina. Condor 115(1):8-16

Coppedge BR, Engle DM, Masters RE, Gregory MS (2004). Predicting juniper encroachment and CRP effects on avian community dynamics in southern mixed-grass prairie, USA. Biol Conserv (3):431-441

Da Silva JMC, Uhl C, Murray G (1996) Plant succession, landscape management, and the ecology of frugivorous birds in abandoned Amazonian pastures. Conserv Biol 10:491-503

Deconchat M, Brockerhoff EG, Barbaro L (2009) Effects of surrounding landscape composition on the conservation value of native and exotic habitats for native forest birds. Forest Ecol Manag 258:S196-204

de Souza W, Barbosa OR, Marques J, Costa MAT, Gasparino E, Limberger E (2010) Microclimate in silvipastoral systems with eucalyptus in rank with different heights. Revista Brasileira de Zootecnica 39:685-694 
del Hoyo J, Elliott A, Sargatal J, Christie DA, de Juana E (eds.) (2014). Handbook of the Birds of the World Alive. Lynx Edicions, Barcelona. http://www.hbw.com. Accessed 01 Sept. 2015

Dias RA, Bastazini VAG, Gonçalves MSS, Bonow FC, Müller SC (2013) Shifts in composition of avian communities related to temperate-grassland afforestation in southeastern South America. Iheringia, Serie Zoologia 103(1):12-19

Diaz M, Carbonell R, Santos T, Telleria J (1995) Breeding bird communities in pine plantations of the Spanish plateaux: biogeography, landscape and vegetation effects. J Appl Ecol 35(4):562-574

Dufrene M, Legendre P. (1997) Species assemblages and indicator species: the need for a flexible asymmetrical approach. Ecol Monogr 67(3):345-366

Economist (2015) Global food security index 2015, a special report. Economist 17 May 2015.

Fagan WF, Cantrell RS, Cosner C (1999) How habitat edges change species interactions. Am Nat 153:165182

FAO (2010) Global Forest Resources Assessment 2010 - Main report. FAO Forestry Paper 163, Food and Agriculture Organization of the United Nations, Rome, Italy

Filloy J, Bellocq MI (2006) Spatial Variations in the Abundance of Sporophila Seedeaters in the Southern Neotropics: Contrasting the Effects of Agricultural Development and Geographical Position. Biodivers Conserv 15(10):3329-3340

Flaspohler DJ, SA Temple, Rosenfield R (2001) Species-specific edge effects on nest success and breeding bird density in a forested landscape. Ecol Appl 11:32-46

Flaspohler DJ, SA Temple, Rosenfield R (2001) The effects of forest edges on Ovenbird demography in a managed forest landscape. Conserv Biol 15:173-183

Fletcher RJ (2005) Multiple edge effects and their implications in fragmented landscapes. J Anim Ecol 74(2):342-352

Flynn DFB et al (2009) Loss of functional diversity under land use intensification across multiple taxa. Ecol Lett 12:22-23

Forest Stewardship Council (FSC) (2012) Strategic review on the future of forest plantations. Helsinki, Finland

Fuller RJ (2012) Birds and habitat: relationships in changing landscapes. Cambridge University Press, New York

Gardiner B, Moore J (2014) Creating the Wood Supply of the Future. In Challenges and Opportunities for the World's Forests in the 21st Century (pp. 677-704). Springer Netherlands.

Gardner TA,et al (2008) The cost effectiveness of biodiversity surveys in tropical forests. Ecol Lett 11(2):139-150

Gardner TA, Barlow J, Parry LTW, Peres CA (2007) Predicting the uncertain future of tropical forest species in a data vacuum. Biotropica, 39:25-30

Gates, JE, Gysel LW (1978) Avian nest dispersion and fledging success in field-forest ecotones. Ecology 59:871-883 
Gavier-Pizarro et al (2012) Expansion and intensification of row crop agriculture in the Pampas and Espinal of Argentina can reduce ecosystem service provision by changing avian density. Agric Ecosyst Environ 154:44-55

Giacomo AS, De Casenave JL (2010) Use and importance of crop and field-margin habitats for birds in a Neotropical agricultural ecosystem. Condor 112(2):283-293

Goijman AP, Zaccagnini ME (2008). The effects of habitat heterogeneity on avian density and richness in soybean fields in Entre Ríos, Argentina. Hornero:23(2) 67-76

Goijman AP, Conroy M.J, Bernardos JN, Zaccagnini ME (2015) Multi-Season Regional Analysis of MultiSpecies Occupancy: Implications for Bird Conservation in Agricultural Lands in East- Central Argentina. PLoS ONE 10(6): e0130874. doi:10.1371/journal.pone.0130874

Goldstein JH et al (2012) Integrating ecosystem-service tradeoffs into land-use decisions. PNAS 109(19):7565-7570

Grant TA, Madden E, Berkey GB (2004) Tree and shrub invasion in northern mixed- prairie: implications for breeding grassland birds. Wildl Soc Bull 32:807-818

Henwood WD (2010) Toward a strategy for the conservation and protection of the world's temperate grasslands. Great Plains Research 20:121-134

Instituto Nacional de Tecnología Agropecuaria (INTA) INTA (2009) Plan De Tecnologia Regional 20092011, INTA Centro Regional Entre Ríos. http://inta.gob.ar/documentos/plan-tecnologico-regional2009-2011-centro-regional-entrerios/at_multi_download/file/Plan\%20Tecnológico\%20Regional\%2020092011\%20Centro\%20Regional\%20Entre\%20R\%C3\%ADos.pdf. Accessed 01 Sept. 2015

Instituto Nacional de Tecnología Agropecuaria (INTA) (2015) Estadísticas agroclimáticas mensuales eea Concordia INTA (Serie histórica 1969-2007). http://inta.gob.ar/documentos/estadisticasagroclimaticas-deconcordia/at_multi_download/file/INTA_Concordia_Estadisticas_agroclimaticas.pdf. Accessed 8 Aug. 2015

Jobbágy EG, Baldi G, Nosetto MD (2012). Tree plantation in South America and the water cycle: impacts and emergent opportunities. In Forests in Development: A Vital Balance (pp. 53-63). Springer Netherlands.

Karp DS, Mendenhall CD, Sandí RF, Ehrlich PR, Hadly EA, Daily GC. 2013. Forest bolsters birds, pest control, and coffee yield. Ecol Lett 16(11):1339-1347

Kellerman JL, Johnson MD, Stercho AM, Hackett S (2008) Ecological and economic services provided by birds on Jamaican Blue Mountain Coffee Farms. Conserv Biol 22:1177-1185

Krapovickas S, Di Giacomo AS (1998) Conservation of pampas and campos grasslands in Argentina. Parks $8(3): 47-53$

Kronenberg J (2014) What can the current debate on ecosystem services learn from the past? Lessons from economic ornithology. Geoforum 55:164-177

Lantschner MV, Rusch V, Peyrou C (2008) Bird assemblages in pine plantations replacing native ecosystems in NW Patagonia. Biodivers Conserv 17(5):969-989 
Lay DW (1938) How valuable are woodland clearings to birdlife? Wilson Bull 50:254-256

Leveau LM, Leveau CM (2012) The role of urbanization and seasonality on the temporal variability of bird communities. Landscape Urban Plan 106(3):271-276

Lewis JP, Noetinger S, Prado DE, Barberis IM (2009) Woody vegetation structure and composition of the last relicts of Espinal vegetation in subtropical Argentina. Biodivers Conserv 1518(13):3615-3628

Lindenmayer DB, Cunningham RB, Donnelly CF, Nix H, Lindenmayer BD (2002) Effects of forest fragmentation on bird assemblages in a novel landscape context. Ecol Monographs. 72(1):1-8

Mace GM, Norris K, Fitter AH (2012) Biodiversity and ecosystem services: a multilayered relationship. Trends Ecol Evol 27(1):19-26

Marsden SJ, Whiffin M, Galetti M (2001). Bird diversity and abundance in forest fragments and Eucalyptus plantations around an Atlantic forest reserve, Brazil. Biodivers Conserv 10(5):737-751

Mastrangelo ME, Gavin MC (2012) Trade-offs between cattle production and bird conservation in an agricultural frontier of the Gran Chaco of Argentina. Conserv Biol 26:1040-1051

McCune B, Grace JB, Urban D (2002) Analysis of ecological communities. MjM Software Design, Gleneden Beach, OR

Medan D, Torretta JP, Hodara K, Elba B, Montaldo NH (2011) Effects of agriculture expansion and intensification on the vertebrate and invertebrate diversity in the Pampas of Argentina. Biodivers Conserv 20(13):3077-3100

Millan CH, Develey PF, Verdade LM (2015). Stand-level management practices increase occupancy by birds in exotic Eucalyptus plantations. Forest Ecol Manag 336:174-182

Millennium Ecosystem Assessment (2005) Ecosystems and Human Well-Being: Synthesis. Island Press, Washington, D.C.

Miñarro F, Bilenca D (2008) The Conservation Status of Temperate Grasslands in Central Argentina, a special report. Fundación Vida Silvestre Argentina. Fundación Vida Silvestre Argentina. Buenos Aires. http://awsassets.wwfar.panda.org/downloads/conservation_status_temperate_grasslands.pdf. Accessed 8 Aug. 2015

Moreira F, Beja P, Morgado R, Reino L, Gordinho L, Delgado A, Borralho R (2005) Effects of field management and landscape context on grassland wintering birds in Southern Portugal. Agric Ecosyst Environ 109(1):59-74

Narosky T, Yzurieta D (2010) Birds of Argentina and Uruguay: a Field Guide. Vázquez Mazzini Ed, Buenes Aires, Argentina

Paquette A, Messier C (2009) The role of plantations in managing the world's forests in the Anthropocene. Front Ecol Environ 8(1):27-34

Pascual U, Perrins C (2007) Developing incentives and economic mechanisms for in situ biodiversity conservation in agricultural landscapes. Agric Ecosyst Environ 121:255-268

Perfecto I, Vandermeer J (2010) The agroecological matrix as alternative to the land sparing/agricultural intensification model. Proc Natl Acad Sci USA 107:5786-5791

Poch T, Simonetti JA (2013) Insectivory in Pinus radiata plantations with different degree of structural complexity. For Ecol Manage 304:132-136 
Polasky S, Nelson E, Pennington D, Johnson KA (2010) The Impact of land-use change on ecosystem services, biodiversity and returns to landowners: a case study in the State of Minnesota. Environ Resource Econ 48:219-242

Pretelli MG, Isacch JP, Cardoni DA (2015) Effects of fragmentation and landscape matrix on the nesting success of grassland birds in the Pampas grasslands of Argentina. Ibis. doi: 10.1111/ibi.12292

Quattrocchio ME, Borromei AM, Deschamps CM (2008) Landscape evolution and climate changes in the Late Pleistocene-Holocene, southern Pampa (Argentina): Evidence from palynology, mammals and sedimentology. Quat. Int. 181:123-138

Reino L, Beja P, Osborne PE, Morgado R, Fabião A, Rotenberry JT (2009) Distance to edges, edge contrast and landscape fragmentation: interactions affecting farmland birds around forest plantations. Biol Conserv 142(4):824-838

Sarasola JH, Negro JJ (2006) Role of exotic tree stands on the current distribution and social behavior of Swainson's hawk, Buteo swainsoni in the Argentine Pampas. J Biogeogr 33(6):1096-1101

Schneider NA, Low M, Arlt D, Part T (2012) Contrast in edge vegetation structure modifies the predation risk of natural ground nests in an agricultural landscape. PLOS ONE DOI: 10.1371/journal.pone.0031517

Sekercioglu CH (2006) Increasing awareness of avian ecological function. Trends Ecol Evol 21(8): 464471

SigmaPlot 13 (2015) Systat Software Inc. San Jose, CA, USA

Solbrig OT, Viglizzo EF (1999) Sustainable farming in the Argentine pampas: history, society, economy and ecology. DRCLAS Paper No. 99/00-1. Harvard University, Cambridge, MA

Thompson, I., Mackey, B., McNulty, S., \& Mosseler, A. (2009). Forest resilience, biodiversity, and climate change. In A synthesis of the biodiversity/resilience/stability relationship in forest ecosystems. Secretariat of the Convention on Biological Diversity, Montreal. Technical Series (Vol. 43, pp. 167).

Tomasevic JA, Estades CF (2008) Effects of the structure of pine plantations on their "softness" as barriers for ground-dwelling forest birds in south-central Chile. For Ecol Manage 255: 810-816

Tomich TP et al. (2011) Agroecology: A review from a global change perspective. Annu Rev Environ Resour 36:193-222

Van Bael SA et al. (2008) Birds as predators in tropical agroforestry systems. Ecology 89:928-934

Vickery JA, Tallowin JR, Feber RE, Asteraki EJ, Atkinson PW, Fuller RJ, Brown VK (2001) The management of lowland neutral grasslands in Britain: effects of agricultural practices on birds and their food resources. J Appl Ecol 38:647-664

Viglizzo EF, Frank FC, Carreño L (2006) Situación Ambiental en las Ecorregiones Pampa y Campos y Malezales, In: Brown, A., U. Martínez Ortíz, M. Acerbi \& J. Corcuera (Eds.). La situación ambiental argentina 2005. Fundación Vida Silvestre Argentina. Buenos Aires, pp 263-269 http://www.vidasilvestre.org.ar/descargables/libro_imperdible/pampa.pdf. Accessed 01-09-2015 
Villard M, HachéisệiS (2012) Conifer plantations consistently act as barriers to movement in a deciduous forest songbird: A translocation experiment. Biol Conserv 155:33-37

Vitousek PM, Mooney HA, Lubchanco J, Melillo JM (1997) Human domination of earth's ecosystems. Science 277:494-499

Volpato GH, Prado VM, dos Anjos L (2010) What can tree plantations do for forest birds in fragmented forest landscapes? A case study in southern Brazil. Forest Ecol Manag 260(7):1156-1163

Warner RE (1994) Agricultural land use and grassland habitat in Illinois: Future shock for Midwestern birds? Conserv Biol 8:147-156

Wenny DG, Devault TL, Johnson MD, Kelly D, Sekercioglu, CH, Tomback DF, Whelan CJ (2011) The need to quantify ecosystem services provided by birds. Auk 128(1):1-14

Whelan JC, Sekercioglu CH, Wenny DG (2015) Why birds matter: from economic ornithology to ecosystem services. J Field Ornitho DOI 10.1007/s10336-015-1229-y

Zimmer C (2010) Black is the new green. Conservation Magazine 27 Aug 2011

\section{Tables}

Table 1 Mean bird species richness $(S)$, Shannon's Evenness $(E)$, Shannon's Diversity Index $(H)$, and Simpson's Diversity Index $(D)$ values for each land use type in Entre Ríos province, Argentina. Parentheses show associated standard errors.

\begin{tabular}{lllll}
\hline Land use & $\boldsymbol{S}$ & $\boldsymbol{E}$ & $\boldsymbol{H}$ & $\boldsymbol{D}$ \\
\hline Mature eucalyptus & $6.8 \pm 0.85$ & $0.96 \pm 0.01$ & $1.82 \pm 0.12$ & $0.82 \pm 0.02$ \\
Young eucalyptus & $11.7 \pm 1.20$ & $0.89 \pm 0.06$ & $2.18 \pm 0.22$ & $0.83 \pm 0.06$ \\
Mixed-use farms & $22.8 \pm 2.56$ & $0.91 \pm 0.04$ & $2.83 \pm 0.16$ & $0.91 \pm 0.03$ \\
Pasture/annual crops & $20.5 \pm 2.60$ & $0.94 \pm 0.01$ & $2.82 \pm 0.14$ & $0.93 \pm 0.01$ \\
Espinal savanna & $36.3 \pm 3.25$ & $0.96 \pm 0.00$ & $3.44 \pm 0.09$ & $0.96 \pm 0.00$ \\
\hline
\end{tabular}


Table 2 Bird species identified as significant $(\mathrm{p} \leq 0.05)$ indicators of land use type in Entre Ríos province, Argentina. Indicator values are provided in parentheses (these values scale from 0 to 100 , with a value of 100 suggesting perfect indication). Mature and young eucalyptus stands had no species with significant IVs.

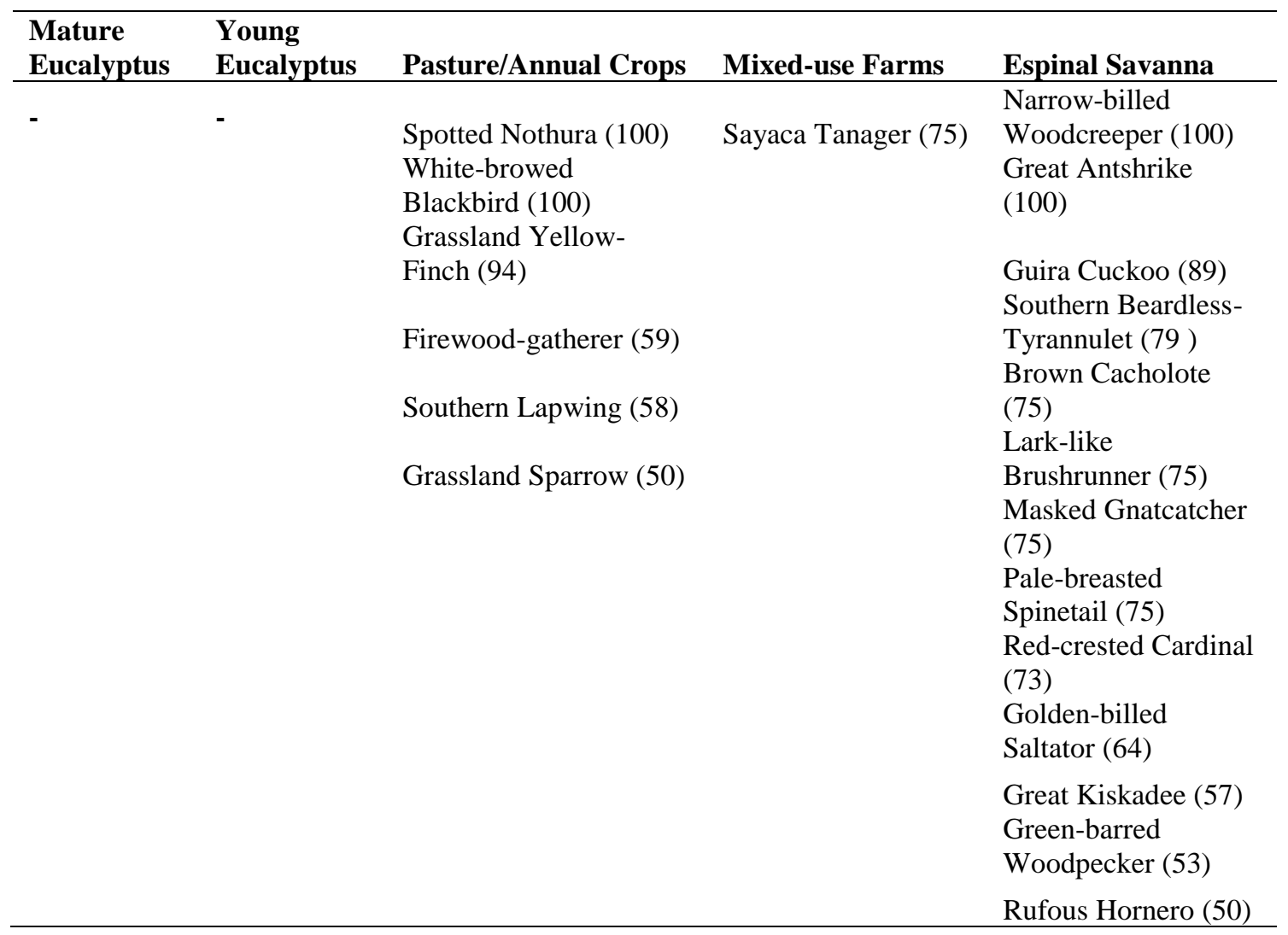




\section{Figures}

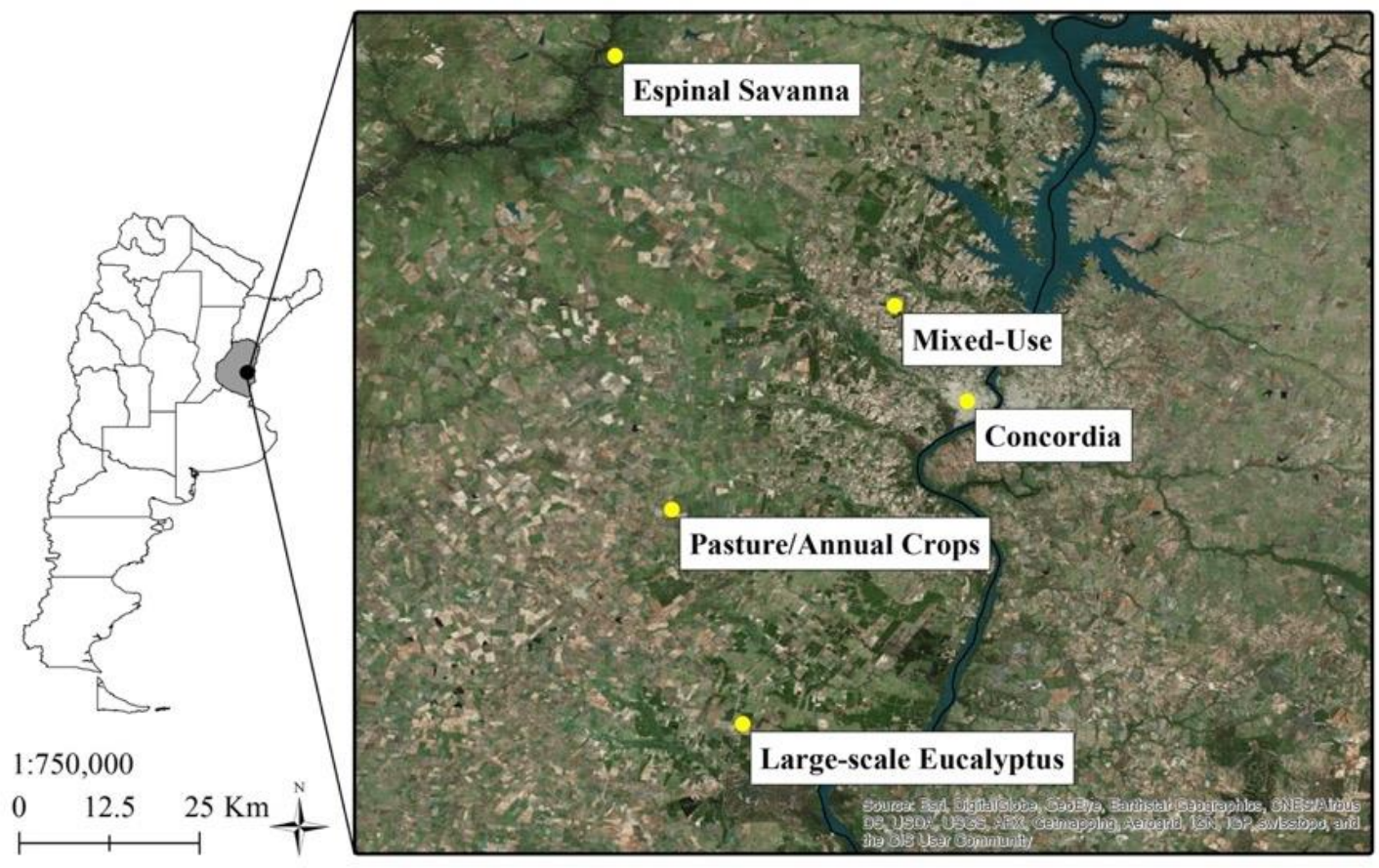

Fig. 1 Map of study site region in Entre Ríos province, Argentina. Research took place in the dominant land uses (pasture/annual crops, small mixed-use farms that include fruticulture, pasture and small stands of eucalyptus, large-scale eucalyptus plantations, both mature and young stands, and espinal savannas). Research was centered near the city of Concordia along the Río Uruguay. 

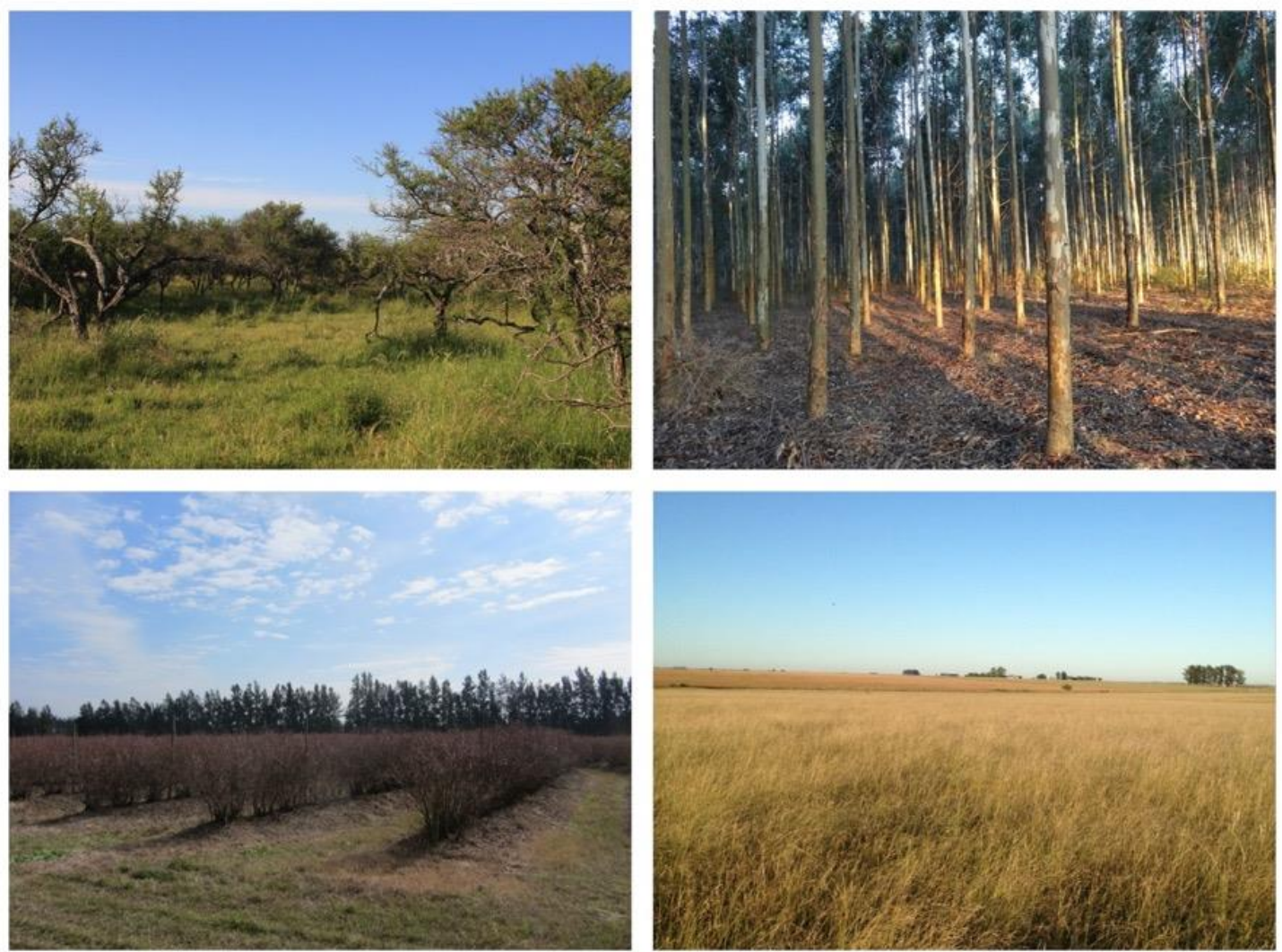

Fig. 2 Examples of the dominant land uses sampled for this research: espinal savanna (top-left), large-scale mature eucalyptus plantations (top-right), mixed-use farms with blueberry (shown) and citrus fields (bottom-left), and managed pasture and annual crops (bottom-right). Young eucalyptus stands feature more understory diversity with more light and habitat heterogeneity. Photo credits: espinal, E. Adams; largescale mature eucalyptus, J. Knowlton; pasture and mixed-use farms, C. Phifer. 


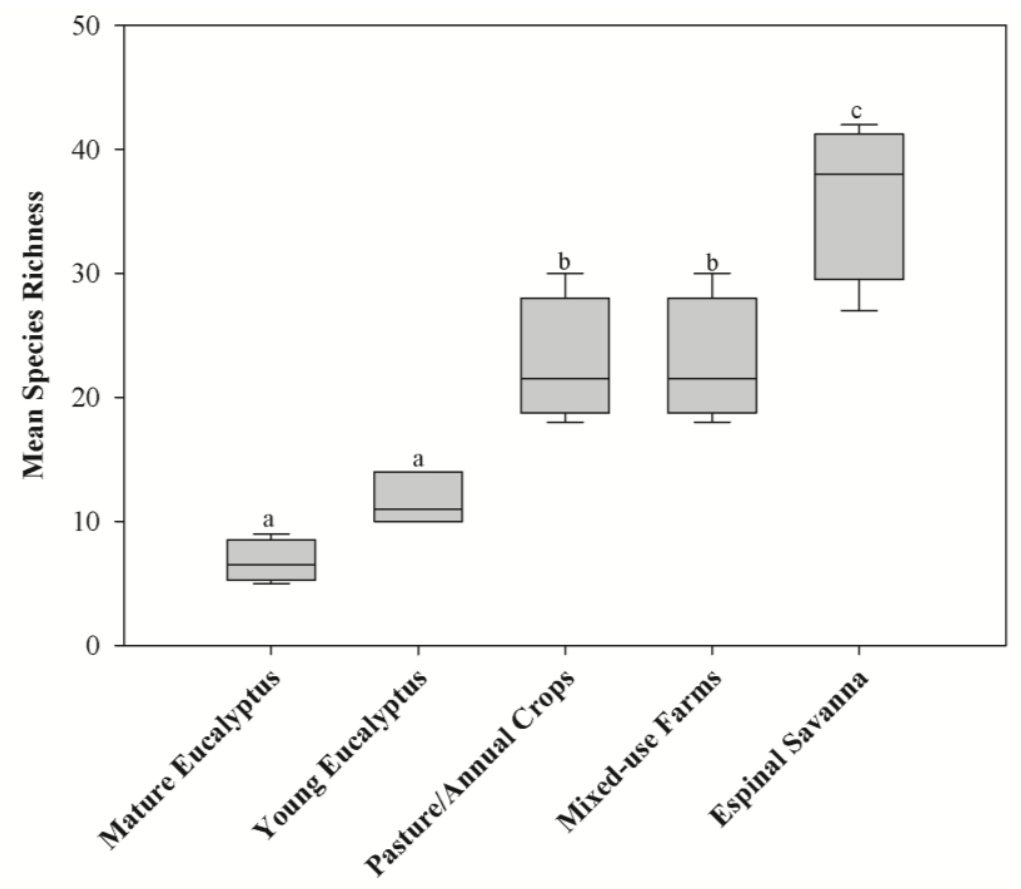

Fig. 3 Boxplots of mean abundance of bird species in five common land uses in Entre Ríos, Argentina. Lines represent minimum, first quartile, median, third quartile, and maximum. Same letters indicate no difference in mean abundance. 


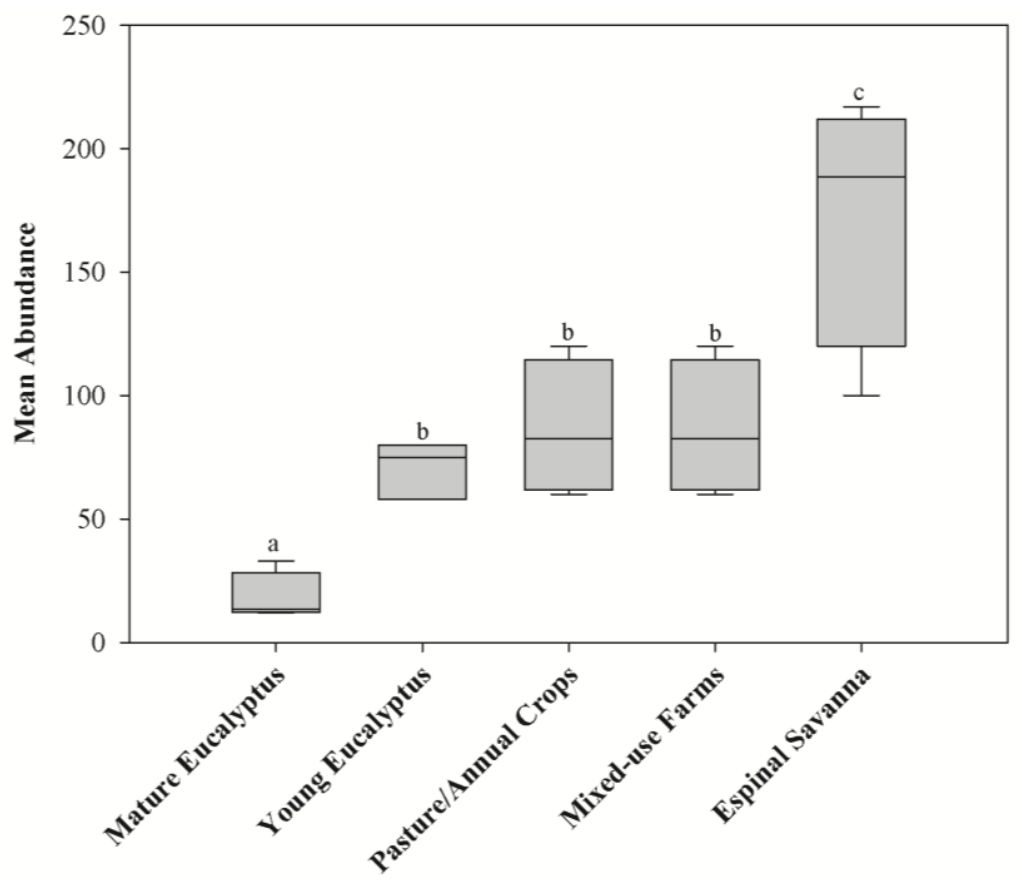

Fig. 4 Boxplots of mean bird species richness five common land uses in Entre Ríos, Argentina. Lines represent minimum, first quartile, median, third quartile, and maximum. Same letters indicate no difference in mean species richness. 


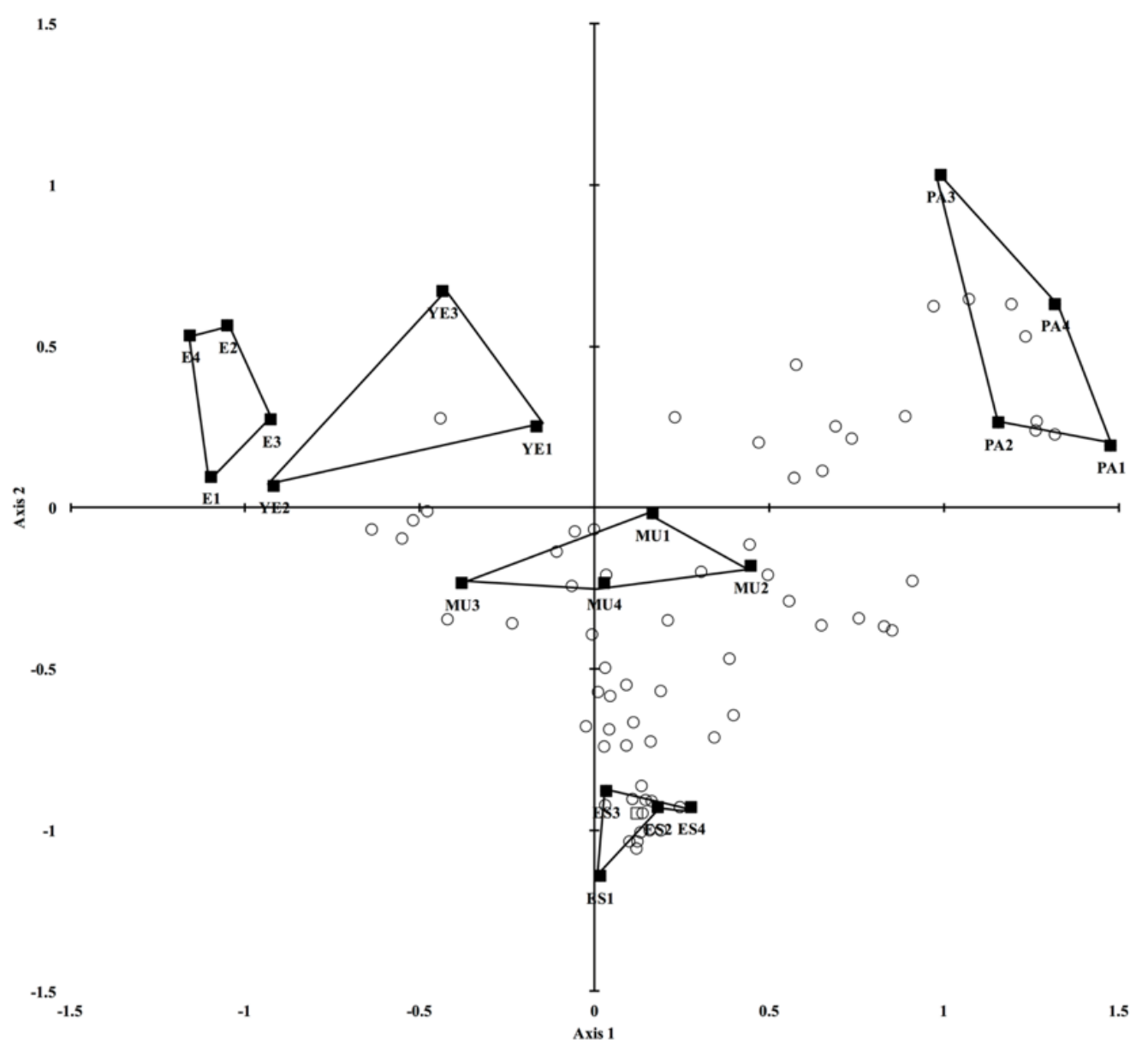

Fig. 5 NMDS ordination plot of bird communities in the pampas region of Entre Ríos province, Argentina. Circles represents individual bird species, and squares land-use replicates. Land uses are bounded by polygons for ease of visualization. Land uses are coded as follows: mature eucalyptus, ME; young eucalyptus, YE; mixed-use farm, MU; pasture/annual crops, PA; espinal savanna, ES. 


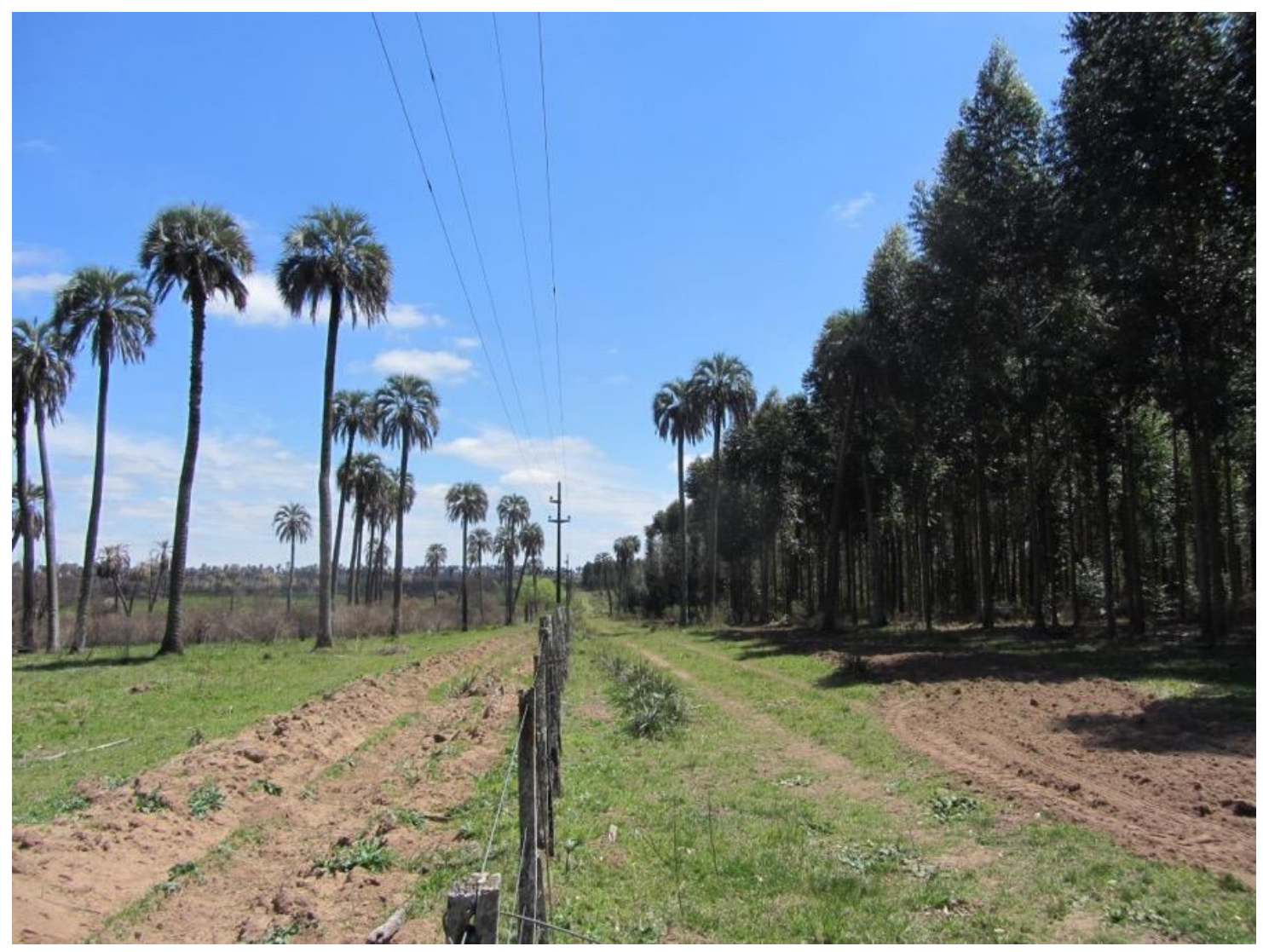

Fig. 6 Property boundary between large-scale eucalyptus plantation and El Palmar National Park where line transects were completed, contrasting the plantation and native grassland of the park. 


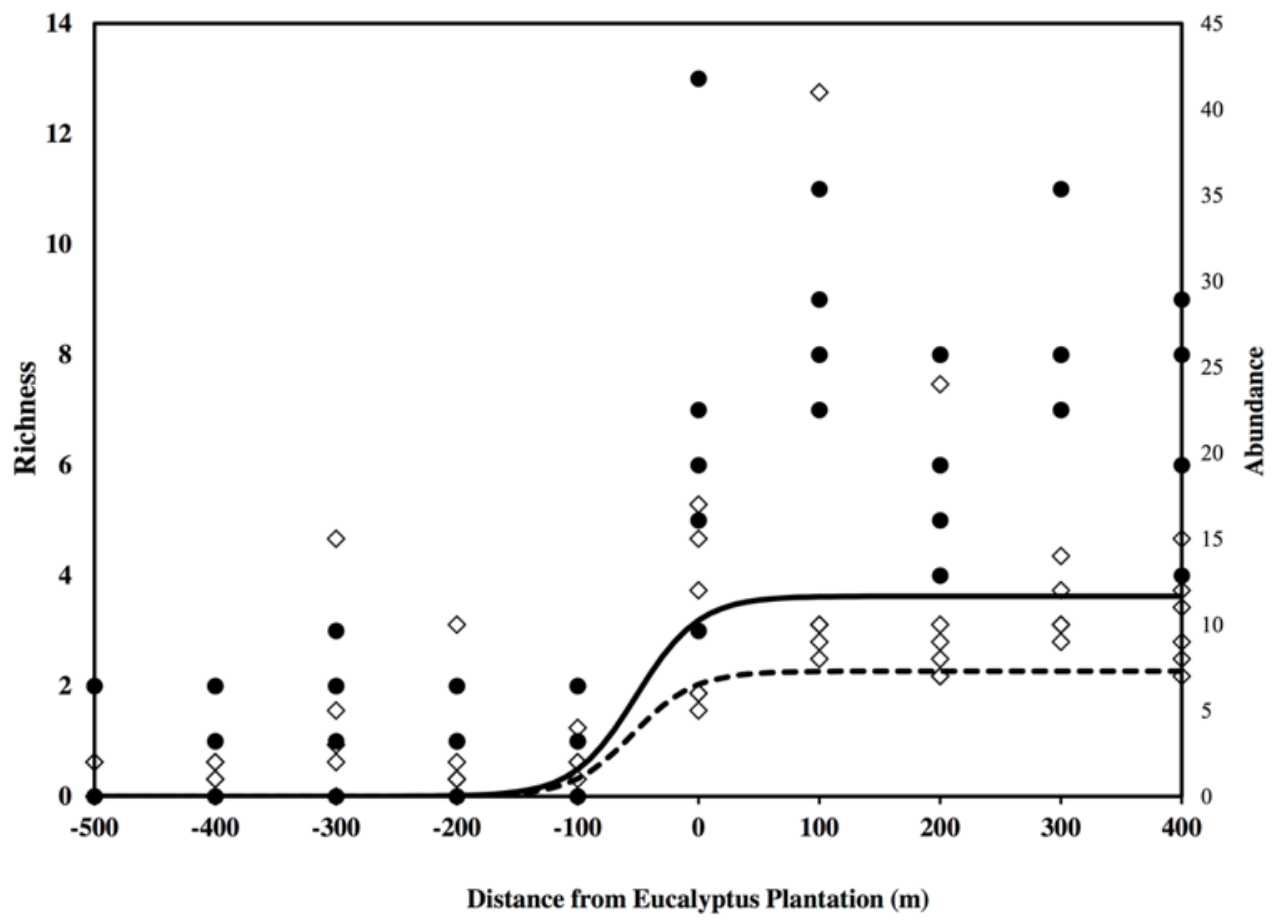

Fig. 7 Species richness and abundances of birds along three $1 \mathrm{~km}$ transects between large-scale eucalypts plantations and adjacent ungrazed grassland at El Palmar National Park. Negative values along the $\mathrm{x}$-axis reflect distance inside the mature eucalyptus stands; positive values represent distances inside grassland; zero denotes the property boundary. The left axis, filled circles and solid regression line represent species richness; right axis, open diamonds and dotted line represent bird abundances. The equation for richness is as follows: richness $=7.29 /(1+\exp (-($ distance- 54.17$) / 25.46))$; abundance $=11.65 /(1+\exp (-($ distance$51.68 / 26.00))$. Both equations are significant $(p$-value $<0.0001)$. 


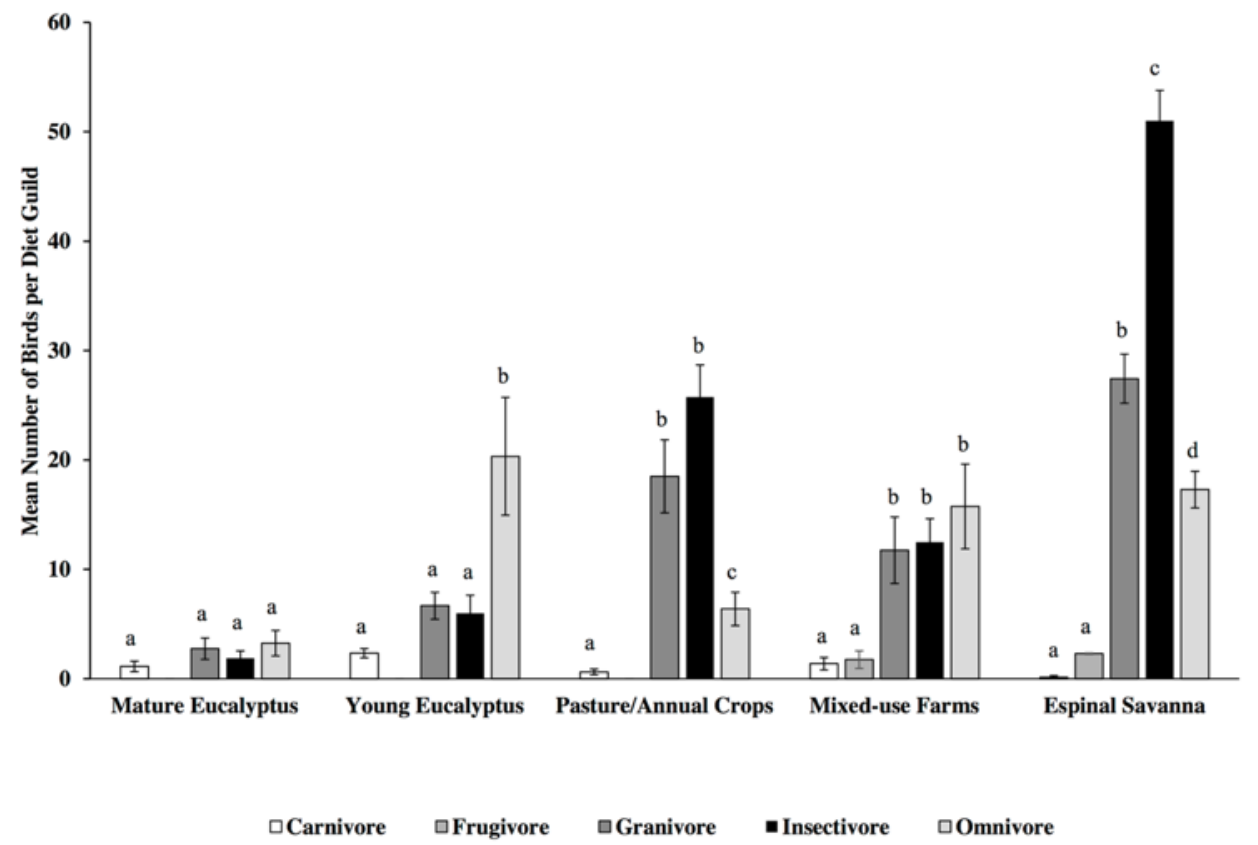

Fig. 8 Mean abundance of five diet guilds of birds across land use types in Entre Ríos, Argentina. Within each land use shared letters denotes no significant difference. Nectivores are not shown since they were only recorded in espinal savanna at low abundance. 


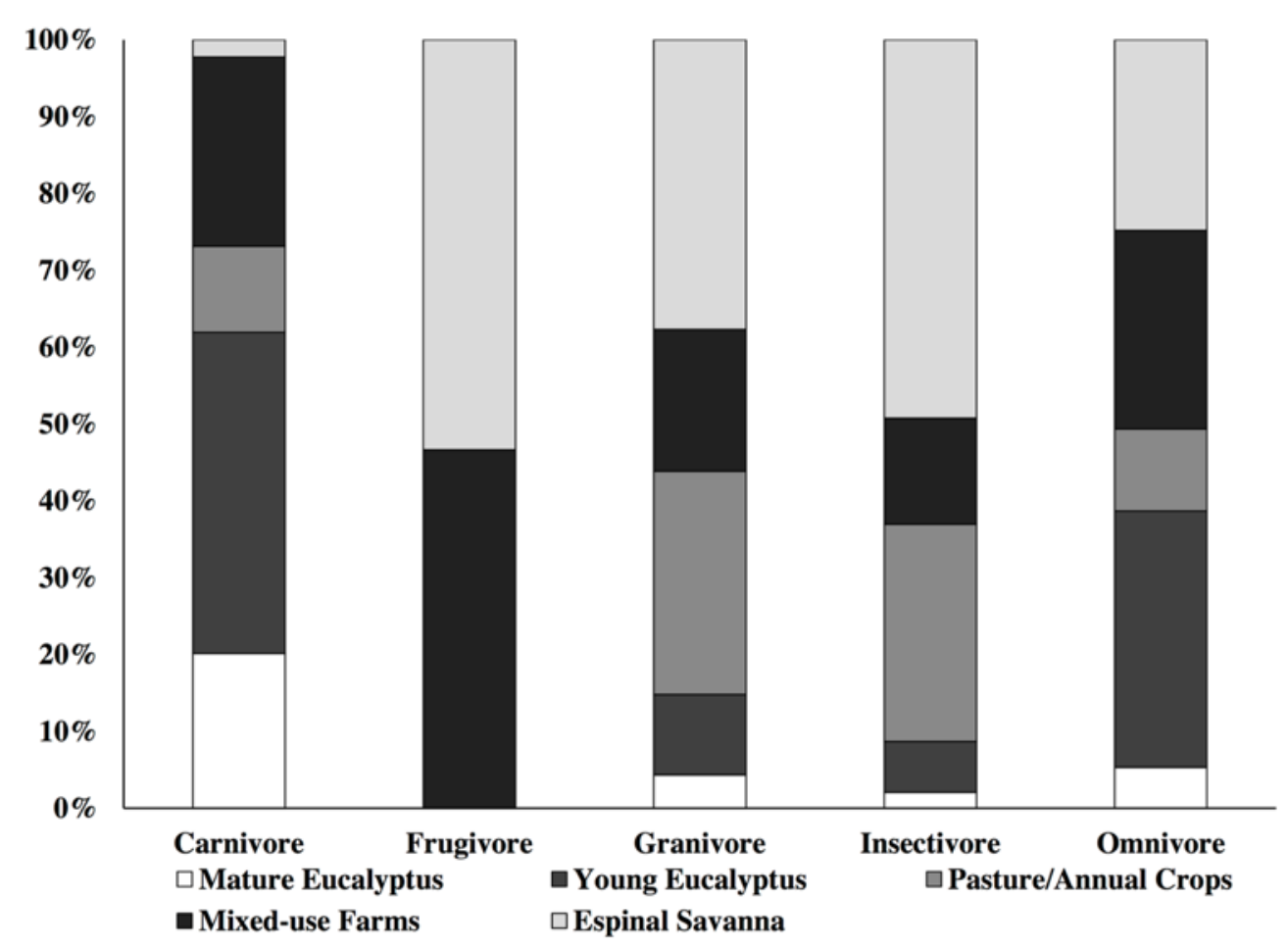

Fig 9 Mean relative abundance of five diet guilds of birds across all land use types in Entre Ríos, Argentina. Nectivores are not shown since they were only recorded in espinal savanna at low abundance 


\section{Appendix}

Appendix A Complete species name, frequency of detection per land use, and diet guide for all birds detected in Entre Ríos, Argentina. Transects were divided by points within the eucalyptus plantation and grassland for comparison. Diet guilds were adopted from del Hoyo et al. 2014. Diet guides include carnivore, $\mathrm{C}$; omnivore, O; insectivore, I; nectivore, N; granivore, G; frugivore, F; and U for unknown.

\begin{tabular}{|c|c|c|c|c|c|c|c|c|c|c|}
\hline Family & Species & Common English Name & 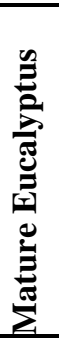 & 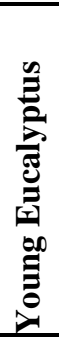 & 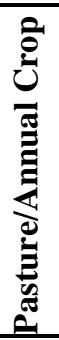 & 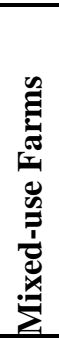 & 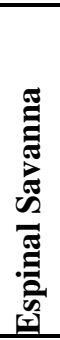 & 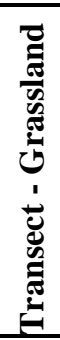 & 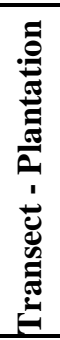 & 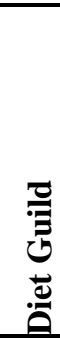 \\
\hline Accipitridae & Accipiter bicolor & Bicolored Hawk & 0 & 0 & 0 & 0 & 0 & 1 & 0 & $\mathrm{C}$ \\
\hline Accipitridae & Buteo magnirostris & Roadside Hawk & 8 & 12 & 1 & 6 & 0 & 6 & 3 & $\mathrm{C}$ \\
\hline Anatidae & Amazonetta brasiliensis & Brazil Duck & 0 & 0 & 2 & 0 & 1 & 0 & 0 & $\mathrm{O}$ \\
\hline Anatidae & Dendrocygna viduata & White-faced Whistling Duck & 0 & 0 & 1 & 0 & 0 & 0 & 0 & $\mathrm{O}$ \\
\hline Ardeidae & Bubulcus ibis & Cattle Egret & 0 & 0 & 1 & 0 & 0 & 0 & 0 & I \\
\hline Ardeidae & Syrigma sibilatrix & Whistling Heron & 0 & 0 & 0 & 1 & 0 & 0 & 0 & I \\
\hline Caprimulgidae & Hydropsalis brasiliana & Scissor-tailed Nightjar & 0 & 1 & 0 & 0 & 0 & 0 & 0 & $\mathrm{I}$ \\
\hline Cardinalidae & Cyanoloxia glaucocaerulea & Glaucous-blue Grosbeak & 0 & 0 & 0 & 0 & 1 & 0 & 2 & $\mathrm{U}$ \\
\hline Cardinalidae & Saltator aurantiirostris & Golden-billed Saltator & 0 & 0 & 0 & 12 & 41 & 0 & 24 & $\mathrm{G}$ \\
\hline Charadriidae & Vanellus chilensis & Southern Lapwing & 0 & 0 & 34 & 7 & 0 & 0 & 0 & I \\
\hline Columbidae & Zenaida auriculata & Eared Dove & 0 & 1 & 5 & 4 & 12 & 0 & 12 & $\mathrm{G}$ \\
\hline Columbidae & Columba picazuro & Picazuro Pigeon & 7 & 14 & 1 & 15 & 10 & 2 & 13 & $\mathrm{G}$ \\
\hline Columbidae & Columbina picui & Picui Ground-Dove & 0 & 1 & 7 & 2 & 1 & 0 & 1 & $\mathrm{G}$ \\
\hline Columbidae & Columba livia & Rock Pigeon & 0 & 0 & 1 & 0 & 0 & 0 & 0 & G \\
\hline Columbidae & Columba maculosa & Spotted Nothura & 0 & 0 & 14 & 0 & 0 & 0 & 0 & $\mathrm{O}$ \\
\hline Columbidae & Leptotila verreauxi & White-tipped Dove & 3 & 5 & 0 & 14 & 6 & 0 & 8 & $\mathrm{G}$ \\
\hline
\end{tabular}




\section{Cuculidae}

Guira guira

Dendrocolaptidae

Dendrocolaptidae

Emberizidae

Emberizidae

Emberizidae

Emberizidae

Emberizidae

Emberizidae

Emberizidae

Emberizidae

Emberizidae

Emberizidae

Emberizidae

Falconidae

w

Falconidae

Falconidae

Falconidae

Fringillidae

Furnaridae

Furnaridae

Furnaridae

Furnaridae

Furnaridae

Furnaridae

Furnariidae

Furnariidae

Hirundinidae

Hirundinidae

Icteridae
Lepidocolaptes angustirostris

Drymornis bridgesii

Volatinia jacarina

Sporophila caerulenscens

Ammodramus humeralis

Sicalis luteola

Embernagra platensis

Donacospiza albifrons

Paroaria coronata

Coryphospingus cucullatus

Zonotrichia capensis

Sicalis flaveola

Cyanocompsa brissonii

Falco sparverius

Falco femoralis

Milvago chimango

Caracara plancus

Carduelis magellanica

Pseudoseisura lophotes

Anumbius annumbi

Phacellodomus sibilatrix

Synallaxis albescens

Synallaxis frontalis

Cranioleuca pyrrhophia

Phacellodomus sibilatrix

Furnarius rufus

Progne tapera

Tachycineta leucorrhoa

Gnorimopsar chopi
Guira Cuckoo

Narrow-billed Woodcreeper

Scimitar-billed Woodcreeper

Blue-black Grassquit

Double-collared Seedeater

Grassland Sparrow

Grassland Yellow-Finch

Great Pampa-Finch

Long-tailed Reed-Finch

Red-crested Cardinal

Red-crested Finch

Rufous-collared Sparrow

Saffron Finch

Ultramarine Grosbeak

American Kestrel

Aplomado Falcon

Chimango Caracara

Southern Caracara

Hooded Siskin

Brown Cacholote

Firewood-gatherer

Lark-like Brushrunner

Pale-breasted Spinetail

Sooty-fronted Spinetail

Stripe-crowned Spinetail

Little Thornbird

Rufous Hornero

Brown-chested Martin

White-rumped Swallow

Chopi Blackbird

$\begin{array}{rrrrrrrl}0 & 0 & 0 & 1 & 10 & 0 & 0 & \mathrm{O} \\ 0 & 0 & 0 & 0 & 23 & 0 & 3 & \mathrm{I} \\ 0 & 0 & 0 & 0 & 8 & 0 & 0 & \mathrm{I} \\ 0 & 0 & 1 & 0 & 1 & 0 & 0 & \mathrm{G} \\ 0 & 0 & 2 & 3 & 0 & 0 & 2 & \mathrm{G} \\ 0 & 3 & 31 & 6 & 0 & 0 & 0 & \mathrm{G} \\ 0 & 0 & 18 & 0 & 1 & 0 & 0 & \mathrm{G} \\ 0 & 0 & 1 & 0 & 0 & 0 & 1 & \mathrm{G} \\ 0 & 0 & 0 & 0 & 0 & 0 & 1 & \mathrm{I} \\ 0 & 0 & 4 & 1 & 22 & 0 & 0 & \mathrm{G} \\ 3 & 2 & 0 & 3 & 1 & 0 & 3 & \mathrm{G} \\ 9 & 51 & 20 & 46 & 43 & 8 & 18 & \mathrm{O} \\ 0 & 1 & 5 & 1 & 9 & 0 & 4 & \mathrm{G} \\ 0 & 0 & 0 & 0 & 1 & 0 & 1 & \mathrm{G} \\ 0 & 0 & 0 & 3 & 0 & 0 & 0 & \mathrm{C} \\ 1 & 0 & 0 & 0 & 0 & 1 & 0 & \mathrm{C} \\ 0 & 2 & 2 & 1 & 0 & 0 & 0 & \mathrm{C} \\ 0 & 0 & 2 & 0 & 1 & 0 & 0 & \mathrm{C} \\ 1 & 0 & 0 & 2 & 0 & 0 & 0 & \mathrm{G} \\ 0 & 0 & 0 & 0 & 6 & 0 & 0 & \mathrm{I} \\ 0 & 1 & 7 & 0 & 0 & 0 & 0 & \mathrm{I} \\ 0 & 0 & 0 & 0 & 4 & 0 & 0 & \mathrm{I} \\ 0 & 0 & 0 & 0 & 9 & 0 & 1 & \mathrm{I} \\ 0 & 0 & 0 & 3 & 7 & 0 & 3 & \mathrm{I} \\ 0 & 0 & 0 & 0 & 6 & 0 & 1 & \mathrm{I} \\ 0 & 0 & 0 & 0 & 1 & 0 & 0 & \mathrm{I} \\ 0 & 0 & 12 & 14 & 44 & 0 & 6 & \mathrm{I} \\ 0 & 0 & 0 & 1 & 0 & 0 & 0 & \mathrm{I} \\ 0 & 0 & 2 & 0 & 0 & 0 & 0 & \mathrm{I} \\ 0 & 0 & 0 & 0 & 2 & 0 & 0 & \mathrm{O}\end{array}$




$\begin{array}{ll}\text { Icteridae } & \text { Icterus cayanensis } \\ \text { Icteridae } & \text { Molothrus rufoaxillaris } \\ \text { Icteridae } & \text { Molothrus bonariensis } \\ \text { Icteridae } & \text { Cacicus solitarius } \\ \text { Icteridae } & \text { Icterus pyrrhopterus } \\ \text { Icteridae } & \text { Sturnella superciliaris } \\ \text { Mimidae } & \text { Mimus saturninus } \\ \text { Motacillidae } & \text { Anthus furcatus } \\ \text { Motacillidae } & \text { Anthus lutescens } \\ \text { Parulidae } & \text { Geothlypis aequinoctialis } \\ \text { Parulidae } & \text { Parula pitiayumi } \\ \text { Passeridae } & \text { Passer domesticus } \\ \text { Picidae } & \text { Colaptes campestris } \\ \text { Picidae } & \text { Picoides mixtus } \\ \text { Picidae } & \text { Colaptes campestris } \\ \text { Picidae } & \text { Colaptes melanochloros } \\ \text { Picidae } & \text { Melanerpes candidus } \\ \text { Picidae } & \text { White-barred } \text { Piculet } \\ \text { Picidae } & \text { Melanerpes cactorum } \\ \text { Picidae } & \text { Veniliornis spilogaster } \\ \text { Polioptilidae } & \text { Polioptila dumicola } \\ \text { Psittacidae } & \text { Myiopsitta monachus } \\ \text { Rallidae } & \text { Aramides ypecaha } \\ \text { Rheidae } & \text { Rhea americana } \\ \text { Scolopacidae } & \text { Gallinago gallinago } \\ \text { Strigidae } & \text { Athene cunicularia } \\ \text { Thamnophilidae } & \text { Taraba major } \\ \text { Thamnophilidae } & \text { Thamnophilus caerulescens } \\ \text { Thraupidae } & \text { Poospiza nigrorufa } \\ \text { Thraupidae } & \text { Poospiza nigrorufa } \\ & \end{array}$

Epaulet Oriole

Screaming Cowbird

Shiny Cowbird

Solitary Black Cacique

Variable Oriole

White-browed Blackbird

Chalk-browed Mockingbird

Short-billed Pipit

Yellowish Pipit

Masked Yellowthroat

Tropical Parula

House Sparrow

Campo Flicker

Checkered Woodpecker

Field Flicker

Green-barred Woodpecker

White Woodpecker

White-barred Piculet

White-fronted Woodpecker

White-spotted Woodpecker

Masked Gnatcatcher

Monk Parakeet

Giant Wood-Rail

Greater Rhea

Common Snipe

Burrowing Owl

Great Antshrike

Variable Antshrike

$\begin{array}{llllllll}0 & 0 & 1 & 0 & 0 & 0 & 0 & \text { I }\end{array}$

Bay-winged Cowbird

Black-and-rufous Warbling-Finch

$\begin{array}{rrrrrrrl}0 & 0 & 1 & 0 & 4 & 0 & 0 & \mathrm{I} \\ 0 & 0 & 2 & 0 & 6 & 0 & 0 & \mathrm{I} \\ 0 & 0 & 0 & 0 & 1 & 0 & 0 & \mathrm{O} \\ 0 & 0 & 0 & 0 & 2 & 0 & 1 & \mathrm{I} \\ 0 & 0 & 27 & 0 & 0 & 0 & 0 & \mathrm{I} \\ 0 & 0 & 4 & 4 & 4 & 0 & 0 & \mathrm{O} \\ 0 & 0 & 1 & 0 & 0 & 0 & 0 & \mathrm{I} \\ 0 & 0 & 10 & 1 & 0 & 0 & 0 & \mathrm{I} \\ 0 & 0 & 0 & 0 & 3 & 0 & 5 & \mathrm{I} \\ 0 & 1 & 0 & 1 & 3 & 1 & 2 & \mathrm{I} \\ 0 & 0 & 1 & 0 & 0 & 0 & 0 & \mathrm{G} \\ 0 & 0 & 0 & 0 & 2 & 0 & 1 & \mathrm{I} \\ 0 & 0 & 0 & 0 & 1 & 0 & 0 & \mathrm{I} \\ 0 & 0 & 0 & 0 & 2 & 0 & 3 & \mathrm{I} \\ 0 & 0 & 0 & 4 & 15 & 0 & 6 & \mathrm{I} \\ 0 & 0 & 0 & 0 & 4 & 0 & 0 & \mathrm{~F} \\ 0 & 0 & 0 & 0 & 0 & 0 & 1 & \mathrm{I} \\ 0 & 0 & 0 & 0 & 6 & 0 & 0 & \mathrm{I} \\ 0 & 0 & 0 & 0 & 0 & 0 & 1 & \mathrm{I} \\ 0 & 1 & 0 & 3 & 26 & 0 & 11 & \mathrm{I} \\ 1 & 0 & 3 & 3 & 7 & 0 & 1 & \mathrm{G} \\ 0 & 0 & 0 & 0 & 1 & 0 & 0 & \mathrm{O} \\ 0 & 1 & 0 & 0 & 0 & 0 & 0 & \mathrm{O} \\ 0 & 0 & 5 & 0 & 0 & 0 & 0 & \mathrm{I} \\ 0 & 0 & 1 & 0 & 0 & 0 & 0 & \mathrm{O} \\ 0 & 0 & 0 & 0 & 13 & 0 & 1 & \mathrm{I} \\ 0 & 0 & 0 & 0 & 0 & 0 & 3 & \mathrm{I} \\ 0 & 0 & 3 & 0 & 2 & 0 & 1 & \mathrm{G} \\ 0 & 0 & 0 & 0 & 0 & 0 & 2 & \mathrm{G}\end{array}$


Thraupidae

Thraupidae

Thraupidae

Thraupidae

Thraupidae

Thraupidae

Thraupidae

Tinamidae

Tinamidae

Trochilidae

Trochilidae

Trochilidae

Troglodytidae

Turdidae

Turdidae

ש

Tyrannidae

Tyrannidae

Tyrannidae

Tyrannidae

Tyrannidae

Tyrannidae

Tyrannidae

Tyrannidae

Tyrannidae

Tyrannidae

Tyrannidae

Tyrannidae

Tyrannidae

Tyrannidae

Tyrannidae
Poospiza melanoleuca

Pipraeidea bonariensis

Sporophila ruficollis

Saltator similis

Piranga flava

Thlypopsis sordida

Thraupis sayaca

Rhynchotus rufescens

Nothura maculosa

Heliomaster furcifer

Hylocharis chrysura

Chlorostilbon aureoventris

Troglodytes aedon

Turdus amaurochalinus

Turdus rufiventris

Polystictus pectoralis

Machetornis rixosa

Empidonomus aurantioatrocristatus

Tyrannus savana

Xolmis cinereus

Pitangus sulphuratus

Elaenia parvirostris

Camptostoma obsoletum

Sublegatus modestus

Myiodynastes maculatus

Suiriri suiriri

Myiarchus swainsoni

Euscarthmus meloryphus

Tyrannus melancholicus

Serpophaga subcristata
Black-capped Warbling-Finch

Blue-and-yellow Tanager

Dark-throated Seedeater

Green-winged Saltator

Lowland Hepatic Tanager

Orange-headed Tanager

Sayaca Tanager

Red-winged Tinamou

Spot-winged Pigeon

Blue-tufted Starthroat

Gilded Hummingbird

Glittering-bellied Emerald

House Wren

Creamy-bellied Thrush

Rufous-bellied Thrush

Bearded Tachuri

Cattle Tyrant

Crowned Slaty Flycatcher

Fork-tailed Flycatcher

Gray Monjita

Great Kiskadee

Small-billed Elaenia

Southern Beardless-Tyrannulet

Southern Scrub-Flycatcher

Streaked Flycatcher

Suiriri Flycatcher

Swainson's Flycatcher

Tawny-crowned Pygmy-Tyrant

Tropical Kingbird

White-crested Tyrannulet

$\begin{array}{rrrrrrrl}1 & 2 & 0 & 2 & 7 & 1 & 5 & \mathrm{G} \\ 0 & 0 & 0 & 1 & 0 & 0 & 0 & \mathrm{~F} \\ 0 & 0 & 4 & 0 & 0 & 0 & 0 & \mathrm{G} \\ 0 & 0 & 0 & 0 & 0 & 0 & 1 & \mathrm{I} \\ 6 & 1 & 0 & 4 & 1 & 1 & 1 & \mathrm{I} \\ 0 & 0 & 0 & 0 & 0 & 2 & 0 & \mathrm{~F} \\ 0 & 0 & 0 & 7 & 2 & 0 & 5 & \mathrm{~F} \\ 0 & 1 & 2 & 0 & 0 & 0 & 0 & \mathrm{O} \\ 0 & 0 & 0 & 2 & 13 & 0 & 1 & \mathrm{G} \\ 0 & 0 & 0 & 0 & 2 & 0 & 0 & \mathrm{~N} \\ 0 & 0 & 0 & 0 & 1 & 0 & 0 & \mathrm{~N} \\ 0 & 0 & 0 & 0 & 1 & 0 & 1 & \mathrm{~N} \\ 0 & 3 & 2 & 7 & 2 & 0 & 5 & \mathrm{I} \\ 1 & 1 & 0 & 5 & 3 & 4 & 26 & \mathrm{I} \\ 0 & 0 & 0 & 1 & 0 & 0 & 0 & \mathrm{~F} \\ 0 & 0 & 1 & 0 & 0 & 0 & 0 & \mathrm{I} \\ 0 & 1 & 3 & 1 & 0 & 0 & 0 & \mathrm{I} \\ 0 & 0 & 0 & 0 & 1 & 0 & 0 & \mathrm{I} \\ 0 & 1 & 3 & 2 & 1 & 0 & 1 & \mathrm{I} \\ 0 & 0 & 0 & 1 & 0 & 0 & 0 & \mathrm{I} \\ 0 & 0 & 1 & 8 & 17 & 0 & 1 & \mathrm{I} \\ 1 & 0 & 0 & 2 & 5 & 0 & 3 & \mathrm{I} \\ 0 & 1 & 0 & 0 & 9 & 0 & 2 & \mathrm{I} \\ 0 & 0 & 0 & 0 & 2 & 0 & 0 & \mathrm{I} \\ 0 & 0 & 0 & 2 & 0 & 0 & 0 & \mathrm{I} \\ 0 & 0 & 0 & 0 & 5 & 0 & 0 & \mathrm{I} \\ 0 & 0 & 0 & 1 & 5 & 0 & 0 & \mathrm{I} \\ 0 & 0 & 0 & 0 & 1 & 0 & 4 & \mathrm{I} \\ 0 & 0 & 0 & 0 & 0 & 0 & 1 & \mathrm{I} \\ 6 & 15 & 0 & 3 & 7 & 3 & 11 & \mathrm{I}\end{array}$




\title{
3. Impact of land-use change and afforested plantations on native bees in northeastern Argentina ${ }^{1}$
}

\begin{abstract}
In Entre Ríos province in northeastern Argentina, large-scale eucalyptus plantations are replacing ranchlands and annual crops, the dominant regional land use/land cover types. These afforested plantations represent a new land use in a region that historically was part of the vast Pampas grassland. Large-scale plantations of even-aged eucalyptus monocultures are likely to continue to expand in this region due to ideal growing conditions, strong markets, and increasingly favorable government incentives. To understand the effects of these plantations on native pollinators, we sampled for bees using pan traps in the eucalyptus plantations and three other common habitats in the region (pasture/croplands, smaller mixed-use farms, and native espinal savanna) for four months in 2014 during the austral spring. We then compared bee abundance, richness, and community structure between land uses. We identified 88 bee species among the 3,152 bees collected from all four habitat types. Relative to other habitats, eucalyptus plantations supported lower bee abundance and species richness. Smaller mixed-use farms had the highest observed abundance of bees, followed by pasture/annual crops and then espinal savanna. Bee community structure in each land use type was distinct with little overlap. Our findings demonstrate the impact of contemporary land-use changes on native bees, which provide valuable pollination services to crops and native plants in the region. Continued expansion of large-scale monoculture plantations may come at the expense of bee habitat and the critical pollination service they provide.
\end{abstract}

\section{Introduction}

Agriculture can alter land use and land cover (LULC) patterns across landscapes and broadly affect biodiversity (Newbold et al., 2015; Tscharntke et al., 2005). Agricultural development reduces and simplifies natural habitats leading to habitat fragmentation and homogenization (Foley et al., 2005). Reconciling agricultural expansion and intensification with biodiversity conservation and economic development remains one of the greatest challenges facing a growing human population.

In Argentina, land-use change associated with agriculture and other commodities has transformed much of the vast Río de la Plata grassland into an export-orientated agricultural landscape dominated by annual crops (e.g., soy and sorghum) and pastures for cattle, leaving a highly fragmented $10 \%$ of the original habitat (Medan et al., 2011) (Fig. 1?). In the last two decades, Entre Ríos province has experienced landscape-level conversion with afforestation from plantations for wood, pulp, and biomass energy (Azpiroz et al., 2012; Baldi and Paruelo, 2008). The total area of afforested plantations is

\footnotetext{
${ }^{1}$ This chapter is intended for Agriculture, Ecosystems and the Environment journal. Please see dissertation preface for details on authors' contributions.
} 
expanding rapidly in Argentina (and, indeed, across South America) because of favorable policies that promote plantation forestry to increase the supply of domestic wood (Argentine law $\mathrm{N}^{\circ} 25.080 \& \mathrm{~N}^{\circ}$ 26.432). Currently, more than 1.2 million ha of plantation forests exist in Argentina, providing more than $90 \%$ of the nation's timber (FAO, 2015).

Entre Ríos province, with its rich soils, favorable climate and low land prices, is experiencing some of the fastest growth of plantation forestry in the country, doubling since the 1980 s and currently accounting for $13 \%$ of the nation's plantations (INTA 2009). In this region, most plantations are Eucalyptus grandis, which accounts for $88.5 \%$ of afforested plantations (INTA 2009), although Pinus spp. are also grown in areas unsuitable for eucalyptus. Afforested plantations alter vegetation by changing soil $\mathrm{pH}$, soil microbes, light availability, and water cycles (Six et al., 2014). Plantations can also impact biodiversity by simplifying avian communities relative to other nearby habitats through lower abundances and species richness compared to other land uses and land cover types (Phifer et al., 2016).

The impact of afforested plantations on native bees and wasps is largely unknown; the majority of the research on plantations and bees has focused on honey bees (Malkamäki et al., 2016) or eucalyptus pest species like gall wasps (Aquino et al., 2011) with little information on plantations as habitats for pollinating bees . Understanding how wild bee populations respond to this type of LULC is critical because of the rapid expansion of tree plantations that now account for 277.9 million hectares worldwide, a full $7 \%$ of the Earth's forests (FAO, 2015). Wild bees provide important pollination services to many agricultural crops and wild plants, including important local crops in the Entre Rios area such as blueberries. Animal-assisted pollination is important for almost $90 \%$ of angiosperms (Ollerton et al. 2011), and insect pollinated crops provide essential calories (Klein et al. 2007) and micronutrients (e.g., vitamin A, iron, and folic acid) needed for human health (Chaplin-Kramer et al. 2014; Ellis et al. 2015). Economically, pollinators contribute to $75 \%$ of crop species, an ecosystem service estimated to be worth approximately $\$ 215$ billion worldwide (Gallai et al., 2009). In addition to managed honeybees, wild, unmanaged pollinators are a major source of this pollination service for many crops (Garibaldi et al., 2016). Even wind-pollinated crops, such as soy, see increased rates of pollination, fruit set and harvest yields because of pollinators, which are more common in adjacent natural and semi-natural habitats (Monasterolo et al., 2015).

The growth in demand for pollinator-dependent crops coincides with a worldwide decline in native and managed bee populations (Potts et al., 2010). The decline in bee populations is likely the result of the confluence of changes in landscape composition, agricultural intensification (Vanbergen et al. 2013), climate change (Miller-Struttmann et al. 2015), diseases and invasive pests (Morales et al. 2013; Fürst et al. 2014; Graystock et al. 2015), and agrochemicals (Whitehorn et al. 2012; Rundlof et al. 2015; Hladik et al. 2016). These forces are often examined independently, but their independent effects are not easily understood because their effects are additive (Goulson et al., 2015). The 
Intergovernmental science-policy Platform on Biodiversity and Ecosystem Services (IPBES) reported a decline in wild bees in North America and Europe (Potts et al., 2016) but less is known about South American bee populations, in part because few long-term bee monitoring has been accomplished in the region (Archer et al., 2014).

In this study, we examined how bees responded to afforested plantations compared to pasture/annual crops, small mixed-use farms and semi-natural native espinal savanna habitats in Entre Ríos province, Argentina. During the austral spring of 2014, we surveyed for native bees in these habitats in the region and compared bee species richness, abundances, and community structure. We hypothesized that bee species richness and overall abundance would be greatest in the native espinal savannas because it has been historically widespread in this region for eons, and because of its greater structural complexity and floral resources. Conversely, we expected the eucalyptus plantations to have the lowest bee biodiversity because of the homogenized environment and lack of floral and nesting resources, and pasture/annual crops and mixed-use farms intermediate to these land uses.. This research fulfilled an urgent need to further understand how bees may respond to the likely acceleration of planting afforest plantations and how biodiversity-dependent ecosystem services, such as pollination, may be impacted by land-use changes.

\section{Materials and methods}

\section{Study area description}

We conducted our research in the Entre Ríos province, Argentina, near the city of Concordia $\left(31^{\circ} 24^{\prime} \mathrm{S} 58^{\circ} 2^{\prime} \mathrm{W}\right.$, Fig. 1). This generally flat area is crisscrossed by small streams that drain into Río Uruguay to the east and the Río Paraná to the west, with gentle rolling hills, and loessic or clay sedimentary soils (Bilenca and Miñarro, 2004). Daily mean temperature is $12.6{ }^{\circ} \mathrm{C}$ during the austral winter and $25.3^{\circ} \mathrm{C}$ during the summer, and the region gets more than $1,300 \mathrm{~mm}$ of rainfall annually (INTA 2015). Agriculture is the dominant industry in region with three primary farm types: 1) expansive pasture for cattle grazing and annual crops (e.g. soybeans) that are often rotated annually; 2 ) large-scale eucalyptus plantations (>500 ha) are generally stocked at 1,000-1200 trees/hectare, which produces monocultures of dense, even-aged stands with little understory vegetation and closed canopies overhead; and 3) smaller family-owned mixed-use farms (generally $<50 \mathrm{ha}$ ) with citrus, blueberry, nuts, and pastures with smaller eucalyptus stands $(<5 \mathrm{ha})$, creating a mosaic of land uses in these areas. Lastly, remnants of the native xerophyte espinal savanna with endemic Butia spp. palms and sparse thorny, short-statured Acacia and Prosopis trees are present, though large, contiguous tracts are rare. Prior to European colonization, espinal savanna covered more of this landscape in this region, and although lightly grazed, it provides high-value habitat for birds ((Phifer et al., 2016). 


\section{Experimental design}

We surveyed bee communities in the four common habitats that characterize the region's agricultural-based economy and account for over $90 \%$ ? of total land cover in the region? (citation?)(described above; Fig. 1B). Each habitat type was first identified using 2013 satellite imagery and GIS software. With the help of local extension agents, we secured landowners' permissions for repeated pollinator sampling. For each agricultural land use, we delineated four 300 ha replicates with at least $75 \%$ of the 300 ha area being covered by the primary land cover. Each replicate was a minimum of one kilometer away from any other replicate. We identified two 300 ha replicates of the espinal savanna because it is a threatened habitat that persists mostly along riparian areas with only a few large contiguous parcels.

\section{Bee sampling}

Bee communities in each land cover type were sampled from September through December 2014 using pan traps, a standard technique used in North America (Lebuhn et al., 2012) and Europe (Westphal et al., 2008), and also used in Argentina for landscape scale studies (Le Féon et al., 2015). We sampled approximately once every three weeks for a total of five sampling periods; we adjusted our sampling to account for forecasted rain and storms to limit exposure. For each land-use replicate, we randomly selected four origin points and installed four $100 \mathrm{~m}$ transects with a 1-m high T-shaped wooden stake every $25 \mathrm{~m}(0,25,50,75$, and $100 \mathrm{~m})$, for a total of five sampling stations per $100 \mathrm{~m}$ transect. If a randomly assigned point would impede normal farm operations or livestock were likely to disturb the pan traps, transects were relocated to the closest available safe location; in these cases, we moved our random point to the nearest location that would not be impacted by farm activities (i.e., on the other side of the fence away from cattle). In total, each land-use replicate had four transects with 20 sampling stations, and each habitat type had 80 sampling stations, with the exception of the espinal savanna, which only had 40 sampling stations. Each $100 \mathrm{~m}$ transect was at least $250 \mathrm{~m}$ from any other transect. At each sampling station, four $300 \mathrm{~mL}$ colored plastic cups (white, blue, yellow, and red) were pinned to the top of the stake (Fig. 2) following methods by XXXXX 2015?. Cups were modified to have drain holes near the lip of cup; we then installed a fine $1 \mathrm{~mm}$ mesh stapled across the holes to prevent any captured insects from washing out in the event of a sudden thunderstorm, which are frequent in the area during spring. Pan traps were filled with soapy water and left for four days each month. Insects were collected and stored in 70\% ethanol and identified to the lowest taxonomic level possible, usually to species. Because we were interested in the bee community and not insect biodiversity per se, we focused our identification efforts on bee members of the Hymenoptera family. A reference library of bees with voucher species for these groups is stored at INTA Concordia Station. 


\section{Data analysis}

We pooled all pan traps per transect and each transect was treated as an independent sample to sum observed abundance and richness totals for each habitat type. We calculated mean richness, evenness, and both Shannon's and Simpson's Diversity Indexes for all habitats. We used then EstimateS 9.1 software (Colwell 2005) to calculate estimators of species richness using first-order Jacknife estimates (Colwell 2013), and we constructed species accumulation curves for each land use type using random method permutations with 100 runs using EstimateS. To compare differences in in observed bee abundance and species richness we tested for differences with a one-way Kruskal-Wallis and post-hoc testing because of the non-normal distribution of our data (Colwell 2013). Because our collection effort was uneven between habitat types (i.e., we often collected fewer traps than we set out because some were destroyed due to moving farm vehicles, livestock, and people) randomly selected 40 samples from the total samples collected per habitat type for this comparison.

To visualize the impact of land-use changes on the pollinator community, we ran a NonMetric Multidimensional Scaling (NMDS) ordination, which simplifies the many interacting species and habitat variables into a simpler dimensional space that can be visualized. We parametrized the NMDS to run for 250 iterations and relativized each column by the most abundant species to smooth over differences between very abundant and less common species (McCune and Grace 2002). Finally, we performed a PERMANOVA test to evaluate for differences between habitat types and bee communities, using the same random samples used for richness and abundance and the four habitat types, followed by a post-hoc pair-wised test for differences,

The focus of our research was on wild bees and related Hymenoptera (i.e. wasps). Managed bees are also common in agricultural landscapes like ours and we observed commercial hives in all habitats and often caught European honeybees (Apis mellifera) . Because of our broader focus on native bee communities' responses to land use and land change, we report abundance and richness values with and without European honeybees. For community level ordination analysis, we ran NMDS and PERMANOVA with and without honeybees, and, finding no differences in the results interpretation, we included them in the analysis for completeness. Statistics were calculated using R 3.3.2 using R Studio and PC-Ord 6.22 (McCune and Mefford 2011).

\section{Results}

We collected 31,951 insects from all land use replicates in our study area. We focused our identification effort on Hymenoptera, specifically pollinating bees, and amassed 3,152 bees from 88 species from six families, including 1,082 European honeybees. A complete species list is available in the Appendix 1.

Total bee abundance varied between habitats and seasonally, with more bees collected later in the season (Figs. 3A and 3B). Mean observed species richness was lowest in the 
large-scale plantations at $3.4( \pm 1.5 \mathrm{SE})$, a tenth of richness found in the pasture/annual crops and mixed-use farms that averaged $30.2( \pm 13.5)$ and $28( \pm 12.5)$ species, respectively. The espinal savanna supported intermediate levels of bee species with a mean of $17.8( \pm 8.8)$ species (Tables 1 - 3 for all biodiversity metrics). Overall abundance patterns for all bees followed this trend as well. However, when honeybees were excluded from abundance totals, pasture/annual crops, had the greatest number of wild bees, with mixed-use farms second, followed by the espinal savanna and finally eucalyptus plantations with 22 wild bees collected (Table 3). Abundance patterns also varied across time for the four habitat we sampled with more bees collected in late spring (Figs. 3A and B, respectively), except for the plantations, which had a consistent low values throughout our sampling period. Species accumulation curves (Fig. 4) for bees show mixed-use farms and pasture-annual/crops were not different from one another, though both were greater than espinal savanna and higher than the plantation's curve.

We identified discrete bee communities within each habitat type. The NMDS resolved the bee species' community to a three-dimensional solution with a final stress level of 10.52 and zero instabilities after 135 iterations (Fig. 5). Cumulatively, the NMDS solution explained $75.6 \%$ of the variation in bee community composition. The PERMANOVA further reinforced the NMDS visualization of significant differences between the habitats and bee communities (Table 4).

\section{Discussion}

We found that large-scale plantations supported significantly fewer bee species compared to agricultural and natural habitats (pasture/annual crops, mixed-use farms and espinal) in the Entre Ríos region of Argentina. Our results support the hypothesis that the large-scale plantations support a depauperate bee community with the lowest relative levels of bee species richness and abundance, compared to other habitats sampled. Interestingly, the highest observed bee abundance was found in the mixed-use farms, with pasture/annual crops second and espinal habitat intermediate. Species accumulation curves showed similar trends as the observed richness, though mixed-use farms and pasture/annual crops curves overlapped. The large-scale plantation curve nearly leveled off, suggesting sampling was sufficient in his habitat while additional sampling would be needed for the other three. Our community ordination results suggest that the bee communities were responding to a strong ecological gradient across the landscapes we sampled, with distinct communities between them (Fig. 5; McCune and Grace 2002).

Our results are consistent with other studies that found that heterogeneous landscapes, such as the mixed-use farms in our study, support diverse group of bees (Kennedy et al., 2013; Winfree et al., 2009) while simplified habitats tend to support few bees (Mallinger et al., 2015). In Entre Ríos, most small-scale farmers plant blueberries, citrus trees, and nut trees along with small-scale eucalyptus stands, and they maintain patches of pastures for grazing. These smaller landowners are more reliant on pollinators for their livelihoods because both blueberries and citrus are pollinator dependent (Chacoff et al., 2010). These mixed-use farms also contained semi-natural or fallow lands that were not being actively 
cultivated, which likely provide more nesting and floral resources for bees (Williams et al., 2010) that the actively managed annual croplands. We also collected the most honeybees on these mix-use farms, the majority of which are likely from managed hives, although we did observe at least one feral colony in the area.

We collected approximately $1 \%$ (24 total individuals and 14 species) of the total of all bees in the mature, large-scale eucalyptus plantations, which suggests that the expansion of these large-scale plantations may result in the displacement and possible loss of wild bees through habitat conversion. Although our collection effort was lower in the plantations, the fact that the species accumulation (Fig. 4) leveled off suggests our sampling was nonetheless sufficient to adequately survey this area. The pampas regions of Argentina and Uruguay are experiencing rapid land-use change and the conversion of predominantly pasture to plantations. Long-term effects may include the loss of bees and the pollination services they provide. Since 1990, the area of plantations in Argentina has grown from 766,000 ha to 1,202,000 (FAO, 2015), and recent changes to the Argentina forestation laws provide tax incentives for plantation forestry, which appears likely to lead to more conversion from pasture to plantations (Prosperi, 2013). The loss of bees within plantations is likely related to the lack of floral and nesting resources beneath the trees. These densely planted plantations provide few floral resources for pollinators directly, likely because of the allopathic nature of eucalyptus, and light limitation and abundance of leaf litter that accumulates beneath the trees that limit seed germination. In addition, the plantations lack loose soil required for ground nesting bees and the trees themselves are not suitable for wood cavity nesters. Outside the tree stands, the plantations usually have wide, $10 \mathrm{~m}$ dirt roads with weedy flowering species and grasses that are nearly absent beneath the dense trees. These roadways and edge habitats likely provide some important floral resources and, along with adjacent pastures or other crops near the plantations, could serve as habitat for bees. Future work should consider a possible edge effects of the plantations, potentially with transect leading in and out of the tree stands, and how bee species perceive the plantation edges as "hard" or "soft."

Here we considered how land uses and agricultural habitats impacts one important taxa group that provides an essential ecosystem service - pollination. Managed bees, wild bees, and other insect pollinators provide pollination services to crops, thus boosting yields (LG 2012, 2016). More broadly, biodiversity itself is a foundational part of ecosystem services (Foley 2009). Although pollination services are often provided by the most common and abundant species (Kleijn et al., 2015), other less abundant species support the whole ecosystem, and a healthy and abundant pollinator community can provide insurance against potential future losses of pollinators in the face of bee declines worldwide (Kleijn et al. 2015, Garibaldi et al 2013).

One limitation of our work is that we did not sample the plantations for bees when the eucalyptus trees flowered; therefore, we cannot assess the ecological value of canopy flowers to native bees. In Brazil, species of wild and managed bees utilized eucalyptus flowers based on pollen analysis, but that species of eucalyptus blooms year-round (Hilgert-Moreira et al. 2014). The species of eucalypt in our study area, E, grandis, 
blooms for 6-8 weeks annually. These flowers provide nectar and pollen for managed bees and eucalyptus-flavored honey ("miel de eucalypto," in Spanish) is considered a regional specialty, so much so beekeepers bring hives to the plantations when the flowers bloom. However, mass-flowering crops, like eucalyptus, can reduce pollination services to other crops and act as a pollinator "sink" during peak bloom periods potentially lowering pollination rates and harvests for adjacent pollinator-dependent crops (Holzchuh et al. 2011). In nearby Uruguay, E. grandis is being replaced by another faster-growing eucalyptus species that does not flower before it is harvested, and beekeepers there are concerned about the loss of the floral resources for their bees (Malkamäki et al 2016). Future research should also directly consider the value of eucalyptus flowers as floral resources for wild bees, and consider the trade-offs with other land uses that provide more consistent and year-round flowering.

This research reflects a snapshot in time, and, although our results are robust, long-term monitoring of how bee populations and communities fluctuate over time should be considered. This is particularly true in Argentina, where native bumble bee populations have declined (Morales et al., 2013) after the introduction of a non-native European bumble bee and its rapid range expansion (Geslin and Morales, 2015; Torretta et al., 2006). Additional sampling, including active netting and nest traps, should also be used to fully account for other species (e.g., large-bodied bees, parasitic species) likely present in this landscape but were not a large part of our sample due to well-known sampling bias of our pan traps that favors flower-visiting and smaller-bodied bees. These complementary methodologies would likely identify more species not collected in pan traps (Lebuhn et al., 2012).

\section{Acknowledgements}

First and second authors (CP and PC, respectively) contributed equally to this project and manuscript. This research was supported by the National Science Foundation

Partnerships for International Research and Education program (grant num. 124344), the USDA McIntire-Stennis program, and the Michigan Technological University Graduate School Finishing Fellowship program. The authors are deeply appreciative to the INTA extension agents, particularly L. Roman, who helped build connections with the many landowners who permitted us to sample on their lands. We also thank the companies of Comercio y Desarrollo S.A. and Com BeyGa Humaitá S.A. who permitted us to sample bees in the large-scale plantations. We further thank the staff of the INTA Concordia Research Station, where our research was based, who helped prepare our bee sampling supplies. Lastly, we thank the anonymous reviewers whose comments helped improve earlier drafts of this manuscript prior to publication.

\section{Literature cited}

Aquino, D.A., Botto, E.N., Loiácono, M.S., Pathauer, P., 2011. "Eucalyptus Gall Wasp" Leptocybe invasa Fischer \& Lasalle (Hymenoptera: Eulophidae: Tetrastichinae) 
in Argentina. RIA 37, 1-6.

Archer, C.R., Pirk, C.W.W., Carvalheiro, L.G., Nicolson, S.W., 2014. Economic and ecological implications of geographic bias in pollinator ecology in the light of pollinator declines. Oikos 123, 401-407. doi:10.1111/j.1600-0706.2013.00949.x

Azpiroz, A.B., Isacch, J.P., Dias, R.A., Di Giacomo, A.S., Fontana, C.S., Palarea, C.M., 2012. Ecology and conservation of grassland birds in southeastern South America: a review. Journal of Field Ornithology 83, 217-246. doi:10.1111/j.1557-9263.2012.00372.x

Baldi, G., Paruelo, J., 2008. Land-Use and Land Cover Dynamics in South American Temperate Grasslands. Ecology and Society, Published online: Aug 01, 2008 | doi:10.5751/ES-02481-130206 13, art6. doi:10.5751/ES-02481-130206

Bilenca, D.N., Miñarro, F., 2004. Identificación De Áreas Valiosas De Pastizal (AVPs) en Las Pampas Y Cam- Pos De Argentina, Uruguay Y Sur De Brasil. Buenos Aires.

Chacoff, N.P., Morales, C.L., Garibaldi, L.A., 2010. Pollinator dependence of Argentinean agriculture: current status and temporal analysis. The Americas Journal ....

Colwell, R. K. 2013. EstimateS: Statistical estimation of species richness and shared species from samples. Version 9. User's Guide and application published at: http://purl.oclc.org/estimates.

FAO, 2015. Global Forest Resources Assessment 2015 1-253.

Foley, J.A., DeFries, R., Asner, G.P., Barford, C., Bonan, G., Carpenter, S.R., Chapin, F.S., Coe, M.T., Daily, G.C., Gibbs, H.K., Helkowski, J.H., Holloway, T., Howard, E.A., Kucharik, C.J., Monfreda, C., Patz, J.A., Prentice, I.C., Ramankutty, N., Snyder, P.K., 2005. Global Consequences of Land Use. Science 309, 570-574. doi:10.1126/science.1111772

Gallai, N., Salles, J.-M., Settele, J., Vaissière, B.E., 2009. Economic valuation of the vulnerability of world agriculture confronted with pollinator decline. Ecological Economics 68, 810-821. doi:10.1016/j.ecolecon.2008.06.014

Garibaldi, L.A., Carvalheiro, L.G., Vaissière, B.E., Gemmill-Herren, B., Hipólito, J., Freitas, B.M., Ngo, H.T., Azzu, N., Sáez, A., Åström, J., An, J., Blochtein, B., Buchori, D., García, F.J.C., da Silva, F.O., Devkota, K., de Fátima Ribeiro, M., Freitas, L., Gaglianone, M.C., Goss, M., Irshad, M., Kasina, M., Filho, A.J.S.P., Kiill, L.H.P., Kwapong, P., Parra, G.N., Pires, C., Pires, V., Rawal, R.S., Rizali, A., Saraiva, A.M., Veldtman, R., Viana, B.F., Witter, S., Zhang, H., 2016. Mutually beneficial pollinator diversity and crop yield outcomes in small and 
large farms. Science 351, 388-391. doi:10.1126/science.aac7287

Geslin, B., Morales, C.L., 2015. New records reveal rapid geographic expansion of Bombus terrestris Linnaeus, 1758 (Hymenoptera: Apidae), an invasive species in Argentina. cl 11, 1620-5. doi:10.15560/11.3.1620

Goulson, D., Nicholls, E., Botias, C., Rotheray, E.L., 2015. Bee declines driven by combined stress from parasites, pesticides, and lack of flowers. Science 347, 1255957-1255957. doi:10.1126/science. 1255957

Kennedy, C.M., Lonsdorf, E., Neel, M.C., Williams, N.M., Ricketts, T.H., Winfree, R., Bommarco, R., Brittain, C., Burley, A.L., Cariveau, D., Carvalheiro, L.G., Chacoff, N.P., Cunningham, S.A., Danforth, B.N., Dudenhöffer, J.-H., Elle, E., Gaines, H.R., Garibaldi, L.A., Gratton, C., Holzschuh, A., Isaacs, R., Javorek, S.K., Jha, S., Klein, A.M., Krewenka, K., Mandelik, Y., Mayfield, M.M., Morandin, L., Neame, L.A., Otieno, M., Park, M., Potts, S.G., Rundlöf, M., Sáez, A., Steffan-Dewenter, I., Taki, H., Viana, B.F., Westphal, C., Wilson, J.K., Greenleaf, S.S., Kremen, C., 2013. A global quantitative synthesis of local and landscape effects on wild bee pollinators in agroecosystems. Ecology Letters 16, 584-599. doi:10.1111/ele.12082

Kleijn, D., Winfree, R., Bartomeus, I., Carvalheiro, L.G., Henry, M., Isaacs, R., Klein, A.-M., Kremen, C., M'Gonigle, L.K., Rader, R., Ricketts, T.H., Williams, N.M., Lee Adamson, N., Ascher, J.S., Báldi, A., Batáry, P., Benjamin, F., Biesmeijer, J.C., Blitzer, E.J., Bommarco, R., Brand, M.R., Bretagnolle, V., Button, L., Cariveau, D.P., Chifflet, R., Colville, J.F., Danforth, B.N., Elle, E., Garratt, M.P.D., Herzog, F., Holzschuh, A., Howlett, B.G., Jauker, F., Jha, S., Knop, E., Krewenka, K.M., Le Féon, V., Mandelik, Y., May, E.A., Park, M.G., Pisanty, G., Reemer, M., Riedinger, V., Rollin, O., Rundlöf, M., Sardiñas, H.S., Scheper, J., Sciligo, A.R., Smith, H.G., Steffan-Dewenter, I., Thorp, R., Tscharntke, T., Verhulst, J., Viana, B.F., Vaissière, B.E., Veldtman, R., Westphal, C., Potts, S.G., 2015. Delivery of crop pollination services is an insufficient argument for wild pollinator conservation. Nature Communications 6, 7414-9. doi:10.1038/ncomms8414

Le Féon, V., Poggio, S.L., Torretta, J.P., Bertrand, C., Molina, G.A.R., Burel, F., Baudry, J., Ghersa, C.M., 2015. Diversity and life-history traits of wild bees (Insecta: Hymenoptera) in intensive agricultural landscapes in the Rolling Pampa, Argentina. Journal of Natural History 50, 1175-1196. doi: $10.1080 / 00222933.2015 .1113315$

Lebuhn, G., Droege, S., Connor, E.F., Gemmill-Herren, B., Potts, S.G., Minckley, R.L., Griswold, T., Jean, R., Kula, E., Roubik, D.W., Cane, J., Wright, K.W., Frankie, G., Parker, F., 2012. Detecting Insect Pollinator Declines on Regional and Global Scales. Conservation Biology 27, 113-120. doi:10.1111/j.15231739.2012.01962.x 
Malkamäki, A., Toppinen, A., Kanninen, M., 2016. Impacts of land use and land use changes on the resilience of beekeeping in Uruguay. Forest Policy and Economics 70, 113-123. doi:10.1016/j.forpol.2016.06.002

Mallinger, R.E., Gibbs, J., Gratton, C., 2015. Diverse landscapes have a higher abundance and species richness of spring wild bees by providing complementary floral resources over bees' foraging periods. Landscape Ecol 1-14. doi:10.1007/s10980-015-0332-Z

McCune B, Grace JB, Urban D, 2002. Analysis of ecological communities. MjM Software Design, Gleneden Beach, OR

Medan, D., Torretta, J.P., Hodara, K., la Fuente, de, E.B., Montaldo, N.H., 2011. Effects of agriculture expansion and intensification on the vertebrate and invertebrate diversity in the Pampas of Argentina. Biodivers Conserv 20, 3077-3100. doi:10.1007/s10531-011-0118-9

Monasterolo, M., L, M.M., R, V.G., A, S., 2015. Soybean crops may benefit from forest pollinators. "Agriculture, Ecosystems and Environment" 202, 217-222. doi:10.1016/j.agee.2015.01.012

Morales, C.L., Arbetman, M.P., Cameron, S.A., Aizen, M.A., 2013. Rapid ecological replacement of a native bumble bee by invasive species. Frontiers in Ecology and the Environment 11, 529-534. doi:10.1890/120321

Newbold, T., Hudson, L.N., Hill, S.L.L., Contu, S., Lysenko, I., Senior, R.A., Börger, L., Bennett, D.J., Choimes, A., Ben Collen, Day, J., De Palma, A., Díaz, S., Echeverria-Londoño, S., Edgar, M.J., Feldman, A., Garon, M., Harrison, M.L.K., Alhusseini, T., Ingram, D.J., Itescu, Y., Kattge, J., Kemp, V., Kirkpatrick, L., Kleyer, M., Correia, D.L.P., Martin, C.D., Meiri, S., Novosolov, M., Pan, Y., Phillips, H.R.P., Purves, D.W., Robinson, A., Simpson, J., Tuck, S.L., Weiher, E., White, H.J., Ewers, R.M., Mace, G.M., Scharlemann, J.P.W., Purvis, A., 2015. Global effects of land use on local terrestrial biodiversity. Nature 520, 45-50. doi:10.1038/nature14324

Phifer, C.C., Knowlton, J.L., Webster, C.R., Flaspohler, D.J., Licata, J.A., 2016. Bird community responses to afforested eucalyptus plantations in the Argentine pampas. Biodivers Conserv 79, 1-29. doi:10.1007/s10531-016-1126-6

Potts, S.G., Biesmeijer, J.C., Kremen, C., Neumann, P., Schweiger, O., Kunin, W.E., 2010. Global pollinator declines: trends, impacts and drivers. Trends in Ecology \& Evolution 25, 345-353. doi:10.1016/j.tree.2010.01.007

Potts, S.G., Imperatriz-Fonseca, V.L., Ngo, H.T., 2016. Summary for policymakers of the assessment report of the Intergovernmental Science-Policy Platform on Biodiversity and Ecosystem Services on pollinators, .... 
Prosperi, M., 2013. Wood Production - Argentina 2013.

Six, L.J., Bakker, J.D., Bilby, R.E., 2014. Vegetation dynamics in a novel ecosystem: agroforestry effects on grassland vegetation in Uruguay. Ecosphere 5, art74-15. doi:10.1890/ES13-00347.1

Torretta, J.P., Medan, D., Abrahamovich, A.H., 2006. First record of the invasive bumblebee Bombus terrestris (L.)(Hymenoptera, Apidae) in Argentina. Transactions of the American .... doi:10.17161/jom.v0i71.6520

Tscharntke, T., Klein, A.M., Kruess, A., Steffan-Dewenter, I., Thies, C., 2005. Landscape perspectives on agricultural intensification and biodiversity ecosystem service management. Ecology Letters 8, 857-874. doi:10.1111/j.1461-0248.2005.00782.x

Westphal, C., Bommarco, R., Carré, G., Lamborn, E., Morison, N., Petanidou, T., Potts, S.G., Roberts, S.P.M., Szentgyörgyi, H., Tscheulin, T., Vaissière, B.E., Woyciechowski, M., Biesmeijer, J.C., Kunin, W.E., Settele, J., Steffan-Dewenter, I., 2008. Measuring bee diversity in different European habitats and biogeographical regions. Ecological Monographs 78, 653-671. doi:10.1890/071292.1

Williams, N.M., Crone, E.E., Roulston, T.H., Minckley, R.L., Packer, L., Potts, S.G., 2010. Ecological and life-history traits predict bee species responses to environmental disturbances. Biological Conservation 143, 2280-2291. doi:10.1016/j.biocon.2010.03.024

Winfree, R., Aguilar, R., Vázquez, D.P., Lebuhn, G., Aizen, M.A., 2009. A meta-analysis of bees' responses to anthropogenic disturbance. Ecology 90, 2068-2076. 


\section{Tables}

Table 1. Mean biodiversity metrics ( \pm SEs) for collected bees from each habitat type for austral spring in 2014 in Entre Ríos, Argentina.

\begin{tabular}{|c|c|c|c|c|}
\hline Land Use & Richness & Evenness & $\begin{array}{c}\text { Shannon's } \\
\text { Diversity } \\
\text { Index }\end{array}$ & $\begin{array}{c}\text { Simpson's } \\
\text { Diversity } \\
\text { Index }\end{array}$ \\
\hline $\begin{array}{l}\text { Large-scale } \\
\text { Plantations }\end{array}$ & $3.4( \pm 1.5)$ & $\begin{array}{c}0.55 \\
( \pm 0.25)\end{array}$ & $0.78( \pm 0.35)$ & $0.40( \pm 0.18)$ \\
\hline Pasture/Annual Crops & $\begin{array}{c}30.2 \\
( \pm 13.5)\end{array}$ & $\begin{array}{c}0.79 \\
( \pm 0.35)\end{array}$ & $2.62( \pm 1.17)$ & $0.88( \pm 0.40)$ \\
\hline Mixed-use Farms & $28( \pm 12.52)$ & $\begin{array}{c}0.64 \\
( \pm 0.29)\end{array}$ & $2.13( \pm 0.95)$ & $0.74( \pm 0.33)$ \\
\hline Espinal Savanna & $\begin{array}{c}17.8 \\
( \pm 8.89) \\
\end{array}$ & $\begin{array}{c}0.76 \\
( \pm 0.38) \\
\end{array}$ & $2.16( \pm 1.08)$ & $0.80( \pm 0.40)$ \\
\hline
\end{tabular}

Table 2. Observed species richness of all bees for each habitat from four months of sampling Sept. - Dec. 2014 in 2014 in Entre Ríos, Argentina.

\begin{tabular}{lcccc}
\multicolumn{1}{c}{ Bees families } & $\begin{array}{c}\text { Large-scale } \\
\text { plantations }\end{array}$ & $\begin{array}{c}\text { Pasture/annua } \\
\text { l crops }\end{array}$ & $\begin{array}{c}\text { Mixed-use } \\
\text { farms }\end{array}$ & $\begin{array}{c}\text { Espinal } \\
\text { savanna }\end{array}$ \\
\hline Andrenidae & 1 & 6 & 5 & 0 \\
Apidae * & 5 & 30 & 26 & 19 \\
Colletidae & 1 & 0 & 2 & 0 \\
Halictidae & 6 & 25 & 24 & 10 \\
Megachillidae & 1 & 6 & 5 & 8 \\
Total bees & 14 & 67 & 62 & 37 \\
\hline
\end{tabular}

* includes A. mellifera 
Table 3. Observed abundance of all pollinators for each habitat from four months of sampling Sept. - Dec. 2014 in Entre Ríos, Argentina. European honeybees (Apis mellifera are separated from totals to see differences between managed and wild bees.)

\begin{tabular}{lcccc}
\multicolumn{1}{c}{ Bees families } & $\begin{array}{c}\text { Large-scale } \\
\text { plantations }\end{array}$ & $\begin{array}{c}\text { Pasture/annual } \\
\text { crops }\end{array}$ & $\begin{array}{c}\text { Mixed-use } \\
\text { farms }\end{array}$ & $\begin{array}{c}\text { Espinal } \\
\text { savanna }\end{array}$ \\
\hline Andrenidae & 1 & 7 & 16 & 0 \\
Apidae $^{*}$ & 9 & 92 & 373 & 196 \\
$\quad$ Apis mellifera & 2 & 175 & 786 & 119 \\
Colletidae & 1 & 0 & 3 & 0 \\
Halictidae & 10 & 542 & 303 & 115 \\
Megachillidae & 1 & 7 & 7 & 17 \\
Total wild bees & 22 & 1019 & 702 & 327 \\
All bees & 24 & 1194 & 1488 & 466 \\
\hline
\end{tabular}

* excluding A. mellifera because it is a (likely) managed bee

Table 4. Results of permanova for differences in habitat types and bee communities. Evaluation of differences in species between groups. Design: One-way randomization test of significance of pseudo-F values. Number of randomizations: 4999 Random number seed: 2171 selected by time.

\begin{tabular}{llllll}
\hline Source & d.f. & SS & MS & F & p * \\
\hline Habitat & 3 & 1440.4 & 480.13 & 5.8638 & 0.0002 \\
Residual & 156 & 12773 & 81.88 & & \\
Total & 159 & 14214 & & & \\
Pairwise comparisons & $\mathrm{t}$ & $\mathrm{p}$ & & & \\
Plantation vs. mixed-use & 3.0846 & 0.0002 & & & \\
Plantation vs. pasture/crops & 3.2685 & 0.0002 & & & \\
Plantation vs. espinal & 2.7788 & 0.0002 & & & \\
Mixed-use vs. pasture/crops & 2.3932 & 0.0002 & & & \\
Mixed-use vs. espinal & 1.7741 & 0.0478 & & & \\
Pasture/crops vs. espinal & 1.7392 & 0.0036 & & & \\
\hline
\end{tabular}




\section{Figures}

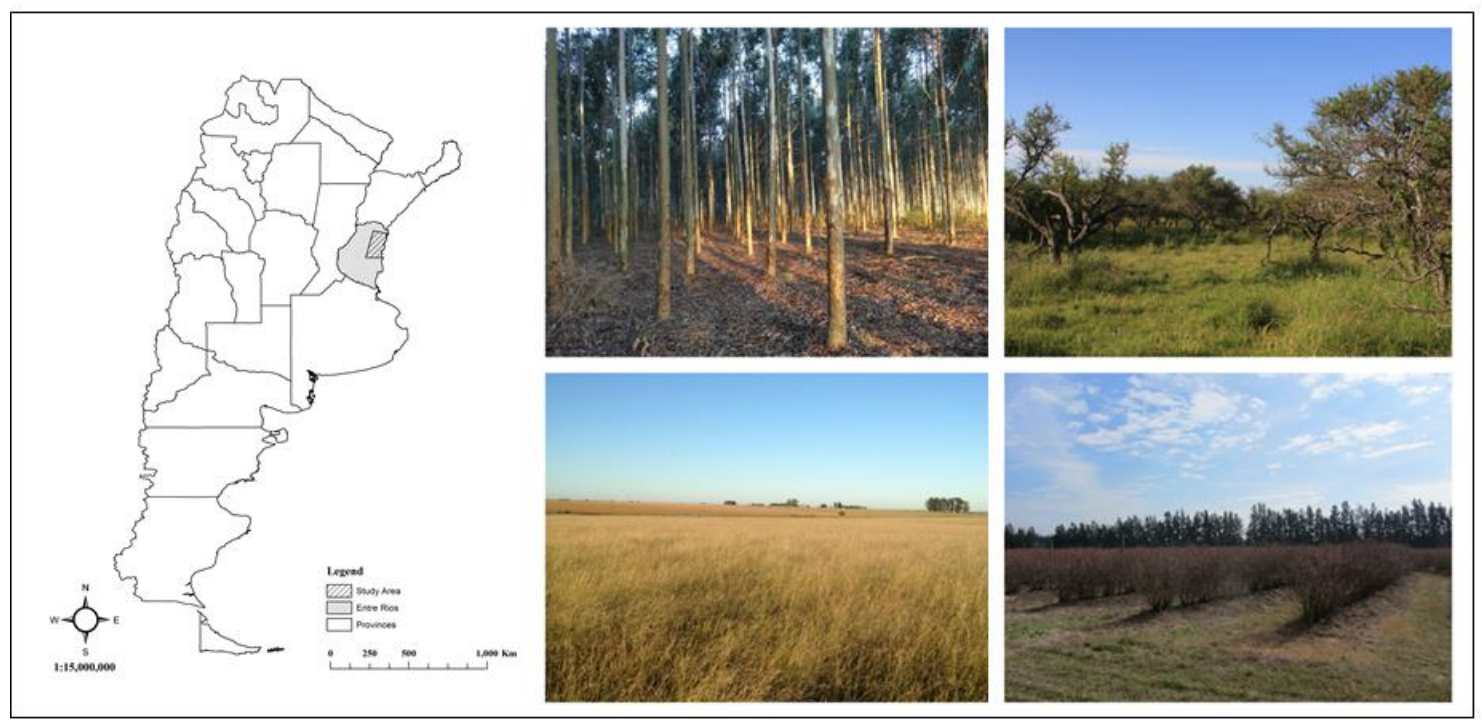

Fig 1. Map of study region with inserts of the common landscape habitats sampled for bees during austral spring in 2014 in Entre Ríos, Argentina. Upper right, eucalyptus plantation understory; lower right, pasture/annual crops; lower left, mixed-use farms; upper left, espinal savanna. Photo credits: C. Phifer. 


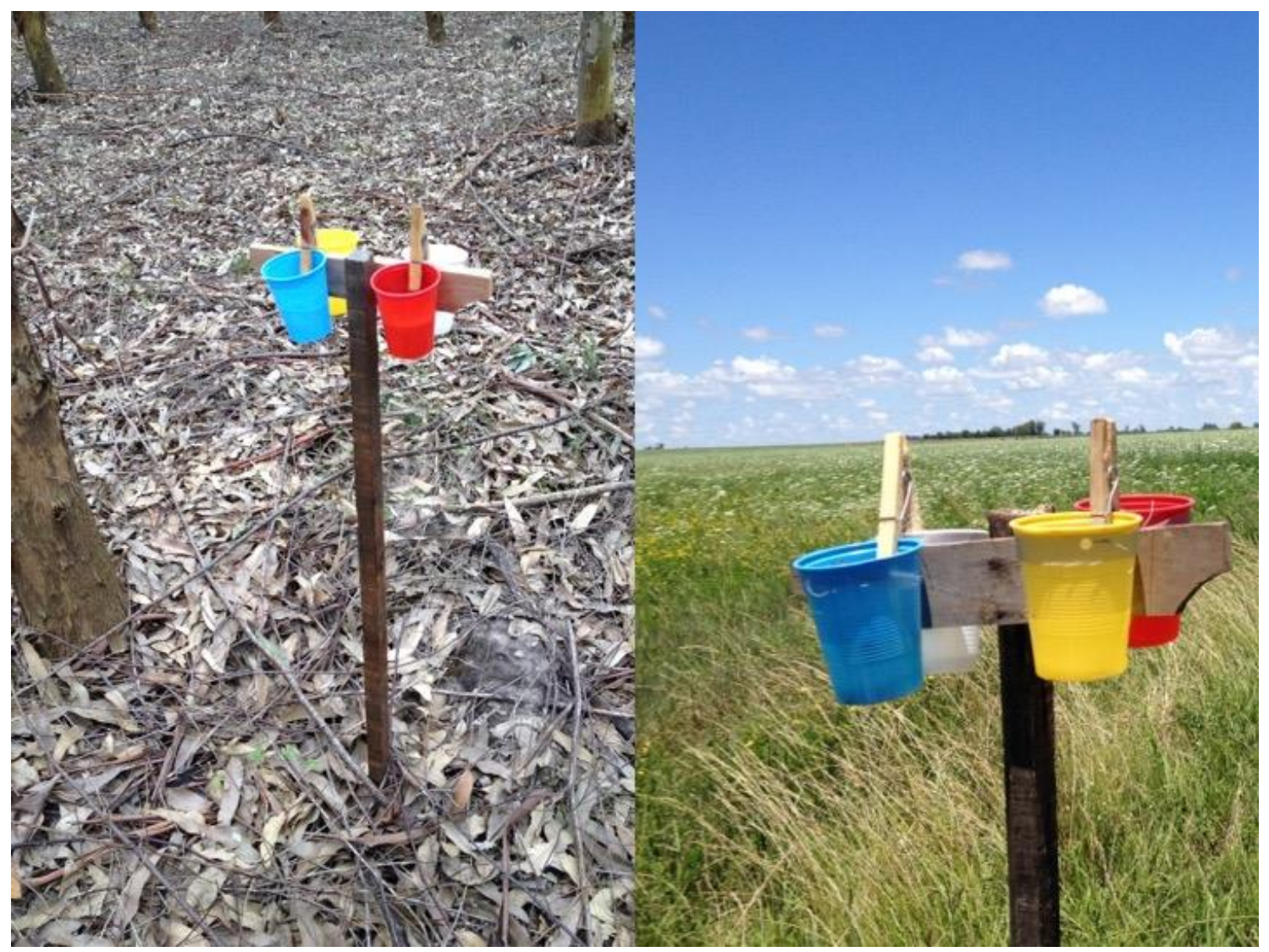

Fig 2. Example of pan traps used for sampling bees and insect pollinators in Entre Ríos, Argentina. Left photo is within a eucalyptus plantation; right photo is near the fence line in pasture. Plastic cups were modified near the lip with drain holes with fine $1 \mathrm{~mm}$ mesh covering them, because of spring storms that could swamp the cups. Photo credits: C. Phifer. 


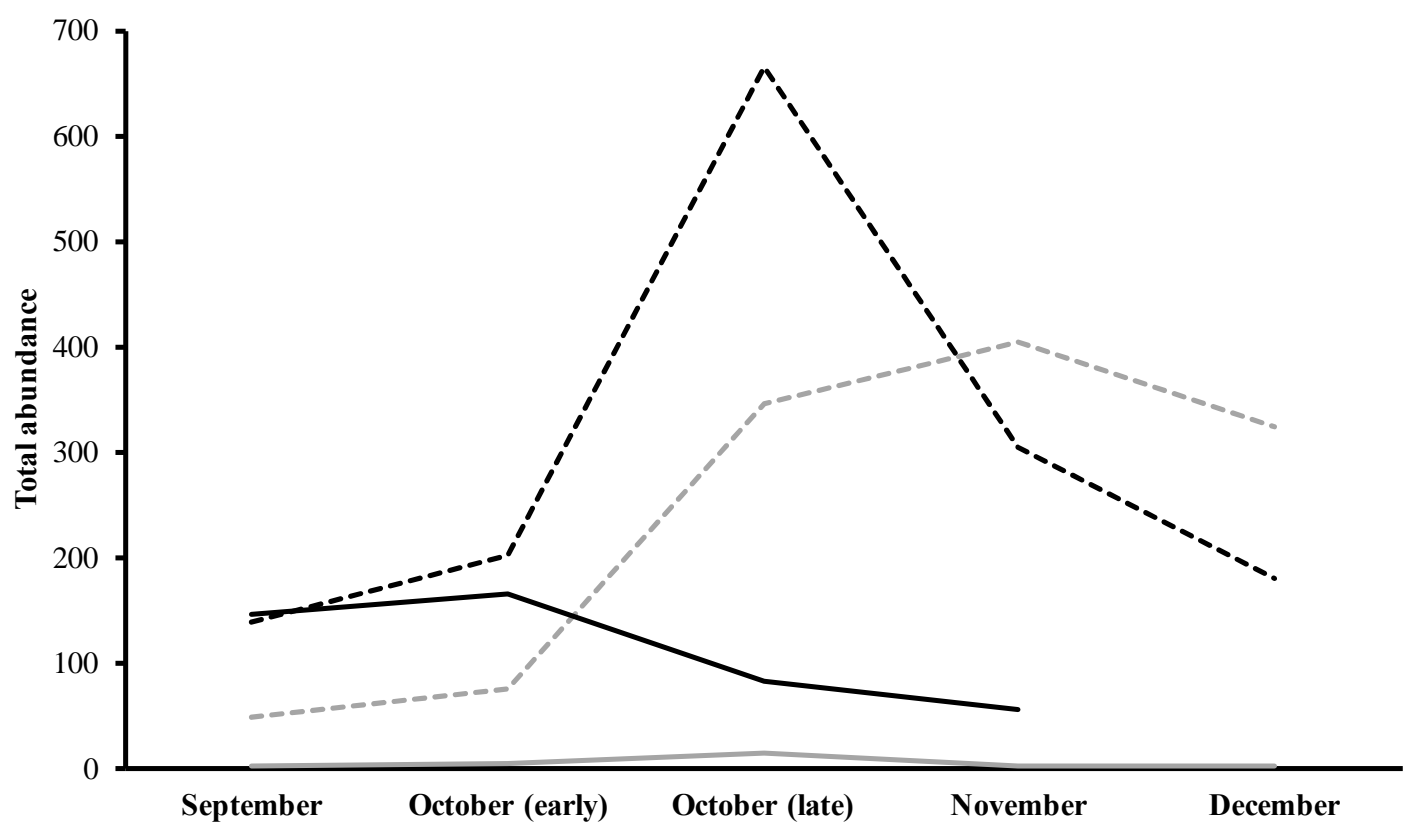

Fig. 3A Total abundance of all bees over the austral spring of 2014 in each habitat type in Entre Ríos, Argentina. Solid grey line is eucalyptus plantations; solid black line is espinal savanna; dashed black line is mixed-use farms; and dashed grey line is pasture and annual crops. 


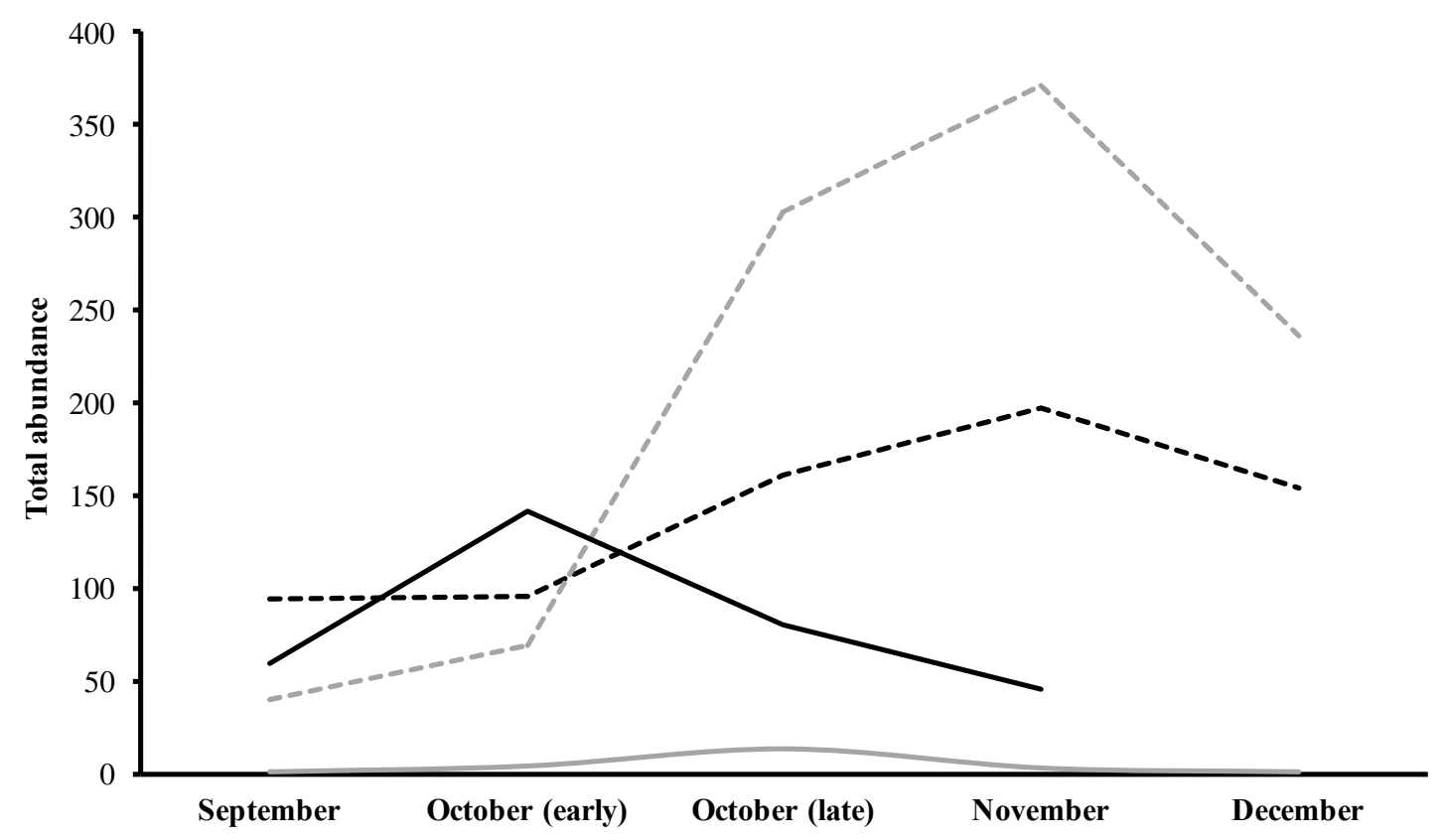

Fig. 3B Total abundance of bees, excluding honey bees, for each LULC type during austral spring in 2014 in Entre Ríos, Argentina. Solid grey line is eucalyptus plantations; solid black line is espinal savanna; dashed black line is mixed-use farms; and dashed grey line is pasture/annual crops. Excluding honeybees, pasture/annual crops supports the most native bees. 


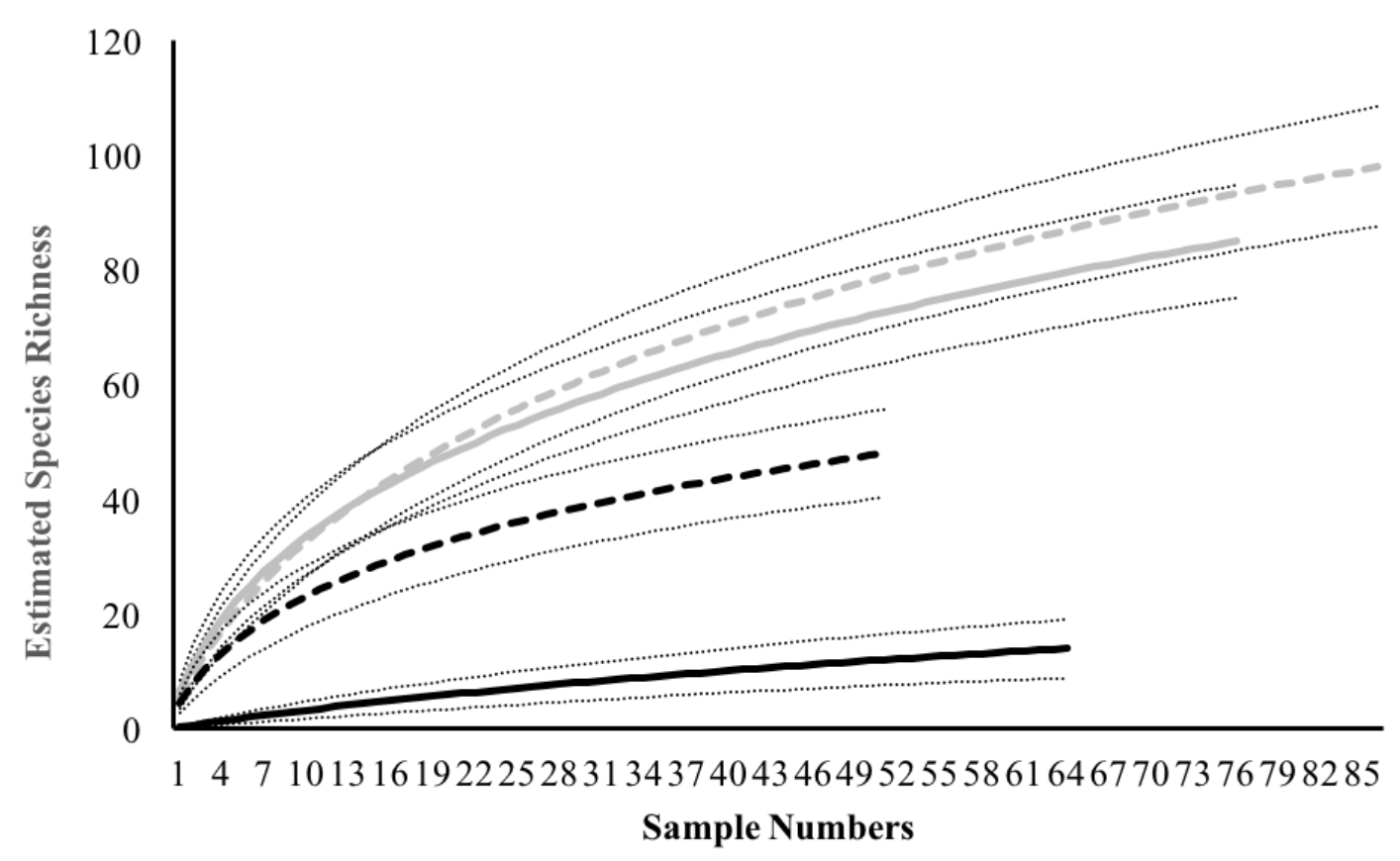

Fig. 4. First order jacknife species richness estimates for bees for each habitat type during austral spring in 2014 in Entre Ríos, Argentina, generated with EstimateS software. Solid black line is plantations; dashed black line is espinal savanna; solid grey line is pasture and annual; and dashed grey line is mixed-use farms. Associated upper and lower 95\% confidence intervals are shown in grey dotted bounding lines. 


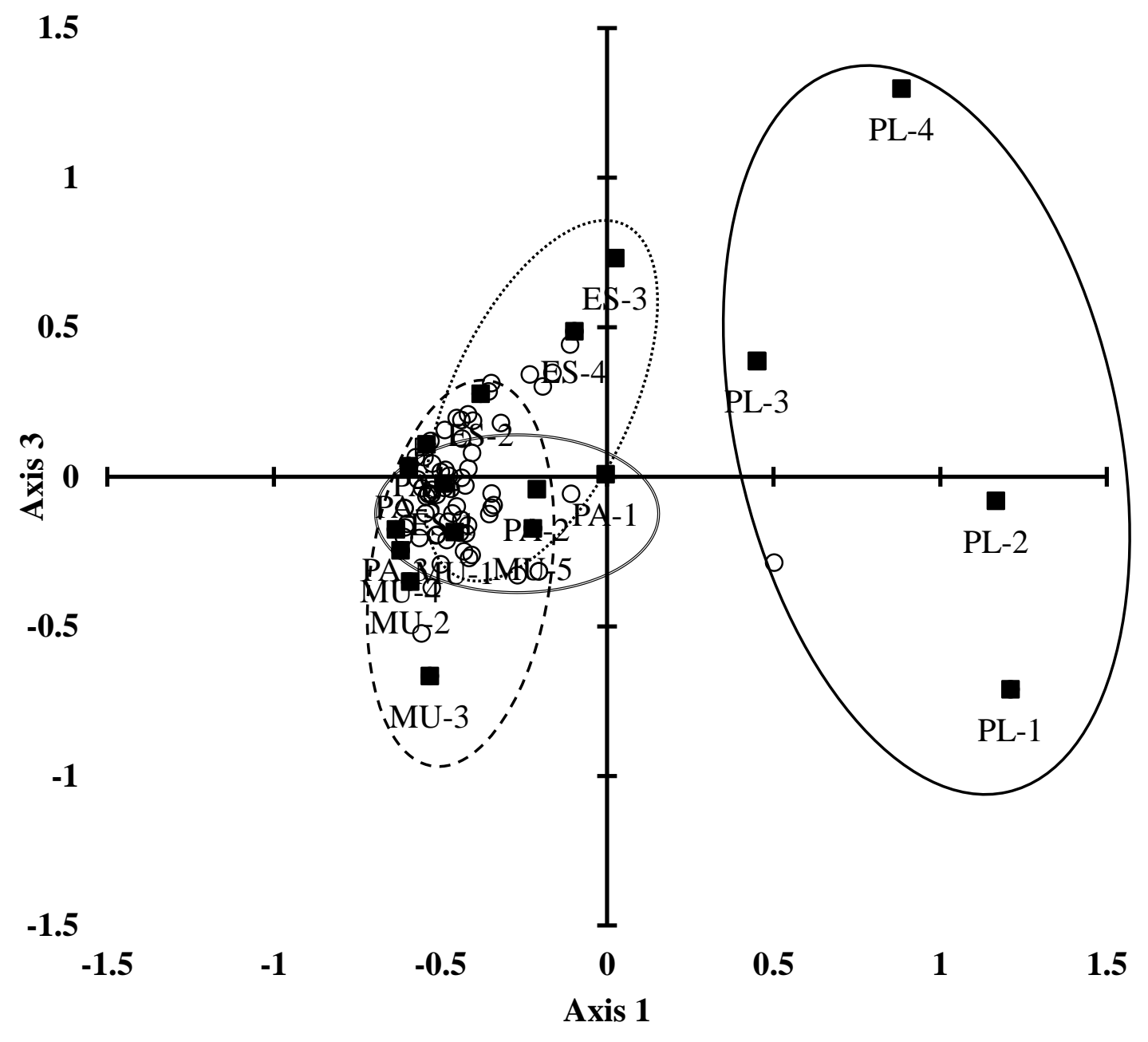

Fig. 5. NMDS ordination for two of the three dimensions of bee species and habitat type from Entre Rios, Argentina. PL = plantations, shown with solid black line; $\mathrm{MU}=$ mixeduse farms with dashed line; PA = pasture/annual crop with a double solid line; ES = espinal savanna with dotted line. Open circles are individual bee species, black squares are individual habitat replicates and polygons are bounding polygons of each habitat type. Greater distance between points suggests greater differences between land uses and land covers. 
Appendix

9 
Appendix 1. Total species richness and abundance for each habitat type for bees collected from Entre Ríos, Argentina in austral spring 2014 over the course of four months. Bees were identified to the lowest taxonomic level possible. A reference collection of bees is stored at INTA Concordia Station

\begin{tabular}{|c|c|c|c|c|c|c|c|}
\hline \multirow[b]{2}{*}{ Family } & \multirow[b]{2}{*}{ Tribe } & \multirow[b]{2}{*}{ Genus Species } & \multicolumn{5}{|c|}{ Abundance } \\
\hline & & & & 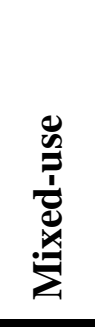 & 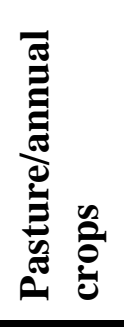 & 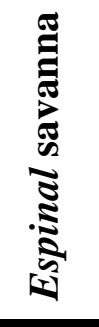 & \\
\hline Andrenidae & Callopsini & Callonychium sp1 & 0 & 7 & 1 & 0 & 8 \\
\hline Andrenidae & Callopsini & Callonychium sp2 & 0 & 5 & 1 & 0 & 6 \\
\hline Andrenidae & Callopsini & Callonychium sp3 & 0 & 1 & 1 & 0 & 2 \\
\hline Andrenidae & Protandrenini & Anthrenoides sp1 & 0 & 0 & 2 & 0 & 2 \\
\hline Andrenidae & Protandrenini & Anthrenoides sp2 & 1 & 2 & 0 & 0 & 3 \\
\hline Andrenidae & Protandrenini & Anthrenoides sp3 & 0 & 0 & 1 & 0 & 1 \\
\hline Andrenidae & Protandrenini & Psaenythia sp1 & 0 & 1 & 0 & 0 & 1 \\
\hline Andrenidae & Protandrenini & Psaenythia sp2 & 0 & 0 & 1 & 0 & 1 \\
\hline Apidae & Apini & Apis mellifera & 2 & 786 & 175 & 119 & 1082 \\
\hline Apidae & Bombini & Bombus pauloensis & 5 & 38 & 2 & 10 & 55 \\
\hline Apidae & Bombini & Bombus belicoso & 0 & 0 & 18 & 0 & 18 \\
\hline Apidae & Centridini & Centris tricolor & 0 & 3 & 1 & 4 & 8 \\
\hline Apidae & Ceratinini & Ceratina morrensis & 0 & 58 & 12 & 5 & 75 \\
\hline Apidae & Ceratinini & Ceratina rupestris & 0 & 74 & 32 & 13 & 119 \\
\hline Apidae & Ceratinini & Ceratina asunciona & 0 & 18 & 2 & 7 & 27 \\
\hline Apidae & Ceratinini & Ceratina caveata & 0 & 5 & 12 & 22 & 39 \\
\hline Apidae & Emphorini & Alepidosceles clavitarsis & 0 & 1 & 2 & 0 & 3 \\
\hline Apidae & Emphorini & Alepidosceles filitarsis & 0 & 9 & 8 & 0 & 17 \\
\hline Apidae & Emphorini & Alepidosceles rufipes & 0 & 3 & 8 & 0 & 11 \\
\hline Apidae & Emphorini & Ancyloscelis romeroi & 0 & 3 & 1 & 0 & 4 \\
\hline
\end{tabular}




$\begin{array}{ll}\text { Apidae } & \text { Emphorini } \\ \text { Apidae } & \text { Emphorini } \\ \text { Apidae } & \text { Emphorini } \\ \text { Apidae } & \text { Emphorini } \\ \text { Apidae } & \text { Emphorini } \\ \text { Apidae } & \text { Eucerini } \\ \text { Apidae } & \text { Eucerini } \\ \text { Apidae } & \text { Eucerini } \\ \text { Apidae } & \text { Eucerini } \\ \text { Apidae } & \text { Eucerini } \\ \text { Apidae } & \text { Eucerini } \\ \text { Apidae } & \text { Eucerini } \\ \text { Apidae } & \text { Tapinotaspidini } \\ \text { Apidae } & \text { Tapinotaspidini } \\ \text { Apidae } & \text { Tapinotaspidini } \\ \text { Apidae } & \text { Tapinotaspidini } \\ \text { Apidae } & \text { Tapinotaspidini } \\ \text { Apidae } & \text { Tapinotaspidinni } \\ \text { Apidae } & \text { Xylocopini } \\ \text { Apidae } & \text { Xylocopini } \\ \text { Apidae } & \text { Xylocopini } \\ \text { Apidae } & \text { Xylocopini } \\ \text { Apidae } & \text { Xylocopini } \\ \text { Colletidae } & \text { Diphaglossini } \\ \text { Colletidae } & \text { Paracolletini } \\ \text { Halictidae } & \text { Augochlorini } \\ \text { Halictidae } & \text { Augochlorini } \\ \text { Halictidae } & \text { Augochlorini } \\ \text { Halictidae } & \text { Augochlorini } \\ \text { Halictidae } & \text { Augochlorini } \\ \text { Halictidae } & \text { Augochlorini } \\ & \\ & \end{array}$

Melitoma sp1

Ptilothrix relata

Ptilothrix scalaris

Ptilothrix sp.1

Ptilothrix tricolor

Florilegus condignus

Gaesischia mimetica

Melissodes tintinnans

Melissodes sp1

Melissoptila desiderata

Svastra detecta

Thygater analis

Caenonomada bruneri

Chalepogenus parvus

Chalepogenus nigripes

Chalepogenus muellerie

Lanthanomelissa clementis

Tapinotaspis chalybaea

Xylocopa artifect

Xylocopa augusti

Xylocopa ciliata

Xylocopa frontalis

Xylocopa splendidula

Ptiloglosa lanosa

Perditomorpha leucostoma

Augochlora anfitrite

Augochlora iphigenia

Augochlora phoemonoe

Augochlorella ephyra

Augochlorella ipoecilla

Augochlorella sp1

$\begin{array}{ccccc}0 & 2 & 0 & 0 & 2 \\ 0 & 0 & 5 & 0 & 5 \\ 0 & 6 & 1 & 0 & 7 \\ 0 & 1 & 0 & 0 & 1 \\ 1 & 0 & 2 & 3 & 6 \\ 0 & 0 & 2 & 0 & 2 \\ 0 & 1 & 0 & 0 & 1 \\ 0 & 3 & 18 & 0 & 21 \\ 0 & 6 & 3 & 0 & 9 \\ 1 & 3 & 93 & 28 & 125 \\ 0 & 0 & 3 & 2 & 5 \\ 0 & 12 & 15 & 1 & 28 \\ 0 & 14 & 141 & 57 & 212 \\ 0 & 0 & 8 & 1 & 9 \\ 2 & 3 & 2 & 4 & 11 \\ 0 & 2 & 0 & 2 & 4 \\ 0 & 2 & 0 & 0 & 2 \\ 0 & 0 & 8 & 0 & 8 \\ 0 & 86 & 20 & 7 & 113 \\ 0 & 18 & 39 & 27 & 84 \\ 0 & 2 & 3 & 1 & 6 \\ 0 & 0 & 1 & 0 & 1 \\ 0 & 0 & 1 & 1 & 2 \\ 0 & 1 & 0 & 0 & 1 \\ 1 & 2 & 0 & 0 & 3 \\ 2 & 2 & 4 & 21 & 29 \\ 0 & 4 & 2 & 0 & 6 \\ 1 & 1 & 7 & 32 & 41 \\ 0 & 29 & 47 & 0 & 76 \\ 0 & 0 & 1 & 0 & 1 \\ 0 & 5 & 2 & 0 & 7\end{array}$




$\begin{array}{ll}\text { Halictidae } & \text { Augochlorini } \\ \text { Halictidae } & \text { Augochlorini } \\ \text { Halictidae } & \text { Augochlorini } \\ \text { Halictidae } & \text { Augochlorini } \\ \text { Halictidae } & \text { Augochlorini } \\ \text { Halictidae } & \text { Augochlorini } \\ \text { Halictidae } & \text { Augochlorini } \\ \text { Halictidae } & \text { Augochlorini } \\ \text { Halictidae } & \text { Augochlorini } \\ \text { Halictidae } & \text { Augochlorini } \\ \text { Halictidae } & \text { Augochlorini } \\ \text { Halictidae } & \text { Augochlorini } \\ \text { Halictidae } & \text { Augochlorini } \\ \text { Halictidae } & \text { Caenolictini } \\ \text { Halictidae } & \text { Caenolictini } \\ \text { Halictidae } & \text { Caenolictini } \\ \text { Halictidae } & \text { Caenolictini } \\ \text { Halictidae } & \text { Halictini } \\ \text { Halictidae } & \text { Halictini } \\ \text { Halictidae } & \text { Halictini } \\ \text { Halictidae } & \text { Halictini } \\ \text { Halictidae } & \text { Halictini } \\ \text { Halictidae } & \text { Halictini } \\ \text { Megachillidae } & \text { Antidinni } \\ \text { Megachillidae } & \text { Lithurgini } \\ \text { Megachillidae } & \text { Megachilini } \\ \text { Megachillidae } & \text { Megachilini } \\ \text { Megachillidae } & \text { Megachilini } \\ \text { Megachillidae } & \text { Megachilini } \\ \text { Megachillidae } & \text { Megachilini } \\ \text { Megachillidae } & \text { Megachilini } \\ & \end{array}$

Augochloropsis brenice

Augochloropsis euterpe

Augochloropsis multiplex

Augochloropsis sp1

Augochloropsis sp2

Augochloropsis sp3

Augochloropsis sp4

Augochloropsis sp5

Augochloropsis sparcilis

Augochloropsis tupacamaru

Augochloropsis zikani

Paraxystoglossa sp1

Thectochlora alaris

Pseudoagapostemon pampeanus

Pseudoagapostemon sp1

Pseudoagapostemon olivaceosplendens

Pseudoagapostemon pulchanus

Dialictus autranellus

Dialictus sp1

Dialictus sp2

Dialictus sp3

Dialictus sp4

Dialictus tinguirica

Epanthidium bicoloratum

Lithurgus rufiventris

Megachile catamarsensis

Megachile guaranitica

Megachile sp1

Megachile cordubensis

Megachile sp2

Megachile sp1

$\begin{array}{ccccc}0 & 5 & 97 & 0 & 102 \\ 0 & 13 & 119 & 0 & 132 \\ 0 & 0 & 5 & 0 & 5 \\ 0 & 5 & 32 & 3 & 40 \\ 1 & 0 & 0 & 0 & 1 \\ 0 & 7 & 16 & 0 & 23 \\ 0 & 3 & 2 & 2 & 7 \\ 2 & 2 & 0 & 1 & 5 \\ 0 & 0 & 1 & 0 & 1 \\ 0 & 5 & 23 & 5 & 33 \\ 0 & 2 & 1 & 0 & 3 \\ 0 & 0 & 1 & 0 & 1 \\ 0 & 16 & 36 & 0 & 52 \\ 1 & 73 & 39 & 1 & 114 \\ 0 & 28 & 4 & 0 & 32 \\ 0 & 1 & 37 & 0 & 38 \\ 0 & 44 & 0 & 0 & 44 \\ 0 & 34 & 29 & 0 & 63 \\ 0 & 2 & 4 & 1 & 7 \\ 0 & 4 & 5 & 0 & 9 \\ 0 & 4 & 0 & 10 & 14 \\ 0 & 12 & 27 & 39 & 78 \\ 3 & 2 & 1 & 0 & 6 \\ 0 & 0 & 0 & 1 & 1 \\ 0 & 0 & 1 & 4 & 5 \\ 0 & 0 & 0 & 4 & 4 \\ 0 & 0 & 0 & 2 & 2 \\ 0 & 1 & 0 & 0 & 1 \\ 0 & 0 & 1 & 0 & 1 \\ 0 & 1 & 1 & 0 & 2 \\ 1 & 0 & 0 & 0 & 1\end{array}$




\begin{tabular}{|c|c|c|c|c|c|c|c|}
\hline Megachillidae & Megachilini & Megachile hoffmannceggiae & 0 & 0 & 1 & 2 & 3 \\
\hline Megachillidae & Megachilini & Megachile sp1 & 0 & 0 & 2 & 2 & 4 \\
\hline Megachillidae & Megachilini & Megachile sp2 & 0 & 1 & 1 & 0 & 2 \\
\hline Megachillidae & Megachilini & Megachile sp3 & 0 & 0 & 0 & 1 & 1 \\
\hline Megachillidae & Megachilini & Megachile sp4 & 0 & 2 & 0 & 0 & 2 \\
\hline Megachillidae & Megachilini & Megachile neoxanthopera & 0 & 2 & 0 & 1 & 3 \\
\hline
\end{tabular}




\title{
4. Impact of afforested eucalyptus plantations on ecosystem services in Entre Ríos, Argentina ${ }^{1}$
}

\begin{abstract}
Ecosystem services (ES) provide essential goods and services to human communities, but many of these services can be impacted by land-use change. In Entre Ríos province, near the city of Concordia, in northeastern Argentina, large-scale eucalyptus plantations are replacing ranchlands and annual crops as the dominant land use. These afforested eucalyptus plantations represent a new land use in a region that was is part of the Pampas grassland. Favorable government policies and market conditions will likely result in the expansion of large-scale monocultures of even-aged eucalyptus stands with unknown consequences for multiple ecosystem services. To clarify and quantify the potential tradeoffs between expanding plantations and ecosystem services, we modeled changes in carbon sequestration, pollination services, and avian biodiversity with InVEST ecosystem service software using both primary and secondary data sources. We first estimated these three ES for a 2013 baseline land use/land cover (LULC) map. We then considered the changes to ES for two future plausible scenarios, one representing a major expansion of eucalyptus and one that limits plantation expansion but increases fruit orchards, a plausible scenario based on interview and survey results with the community. Overall, community members valued the economic opportunities that plantations can provide but also were concerned about the scale of the plantations, changes in the environment, and changes in the culture and ways of life. Respondents were also aware of possible changes to ES and many reported seeing perceived changes in the environment as a result of the plantations. Our results suggest that the expansion of eucalyptus may cause potential declines of pollination service provided by wild bees and avian biodiversity, while increasing carbon sequestration. The degree of eucalyptus expansion drove much of the changes in ecosystem services. Overall, our study illuminates the trade-offs inherent in land-use change and the importance of valuing community perspectives.
\end{abstract}

\section{Introduction}

Global demand for agricultural goods and forest products are growing [1,2], and much of the world's landscapes have already been altered by human activity for human needs $[3,4]$, with major losses for biodiversity $[5,6]$. Wood from natural forests alone cannot meet this demand [7], and plantation forestry, the direct planting and tending of trees for harvest, is already a major component of the global wood products market. Plantation forestry is expanding to meet this increased demand for timber and fiber $[8,9]$, contributing to net forest growth worldwide [10]. Planted forests are also considered an important component of the Paris Climate Change Agreement to meet global goals of limiting temperature rise through sequestration of carbon dioxide by trees [11].

\footnotetext{
${ }^{1}$ This chapter is intended for Sustainability peer-review journal. Please see dissertation preface for details on authors' contributions.
} 
Carbon sequestration by trees is one example of an ecosystem service provided by forests. Ecosystem services (ES) are the goods and services provided to people through naturally occurring processes [12], which are produced by both natural and modified environments. Forests are important providers of multiple ES beyond carbon sequestration, including water regulation, soil stabilization, air filtration and biodiversity conservation $[13,14]$. Like other parts of the natural world, ES can be degraded and impacted by human activity, both directly and indirectly [3]. Many of these ES are a function of the physical structure and condition of the land use and land cover (LULC), and thus can be greatly affected by changes in land management decisions [15]. Beyond the physical structure of the landscape, some ES are provided by the community of species present, such as pollination from wild bees. These biodiversity-dependent ES can be negatively impacted by changes in LULC, such as habitat fragmentation and habitat loss [15].

Much of the emphasis on ES has focused on single ES, ignoring the complex interactions between different ES that can occur [16,17]. At landscape scales, ES can be evaluated using decision-support tools that identify and quantify how ES values vary with LULC types [18]. More than 20 of these tools have been developed [19]; generally all of them work by applying geographic information system (GIS) based models that estimate the values of ES that are dependent upon the biophysical attributes and structure of the landscape, like carbon sequestration of forests, for example. In this manner, metrics of ES can be scaled-up from plot or stand level observations to landscape assessments.

Understanding current and future trends in LULC change and impacts on ES is vital in an ever-changing world since human well-being can be impacted by degradation or loss of ES [15]. One way to understand changes in ES is to create alternative LULC futures and explore the consequences. These alternative futures, or scenarios, can be an important part of the decision-making and envisioning process [20], and can even influence final decisions that can be codified into law [21,22]. Scenarios are simplified, plausible futures based upon a set of assumptions designed to illustrate and model potential consequences in a land-use decision-making context; they are not future predictions but can relate to likely or past land-use trends [23,24]. Such scenarios have been shown to be an effective means to visualize and explore the effects of LULC decisions. For example, the Belize government engaged in scenario planning and ES modeling to help understand how alternative models of coastal development would impact multiple ecosystem services, eventually adopting and writing development rules that supported sustainable fisheries and modest development and tourism increases [25]. The process of scenario development is best done within a specific decision-making context and involves participation of the community [23,26,27]. Beyond biophysical variables and land uses, social values and social license of the impacted community by LULC changes are critically important to incorporate into land-use planning, decision-making and policy implementation [23,28,29]. Land-use policies that more fully involve public input and values are more likely to be successful. 
In the northeastern part of Argentina, LULC changes are accelerating due to the development of afforested plantations, a novel land-use in the region, supported by government incentives and a linked policy that partially restricts logging or converting domestic native forests. The Argentine government recently authorized increased subsidies designed to promote the expansion of forest plantations, increasing the total subsidy available for planting trees by $250 \%$; these subsidies cover expenses associated with new plantation plantings and plantation maintenance (pruning and thinning). The plantation promotion law (25.080) also provides a reliable tax and business environment to encourage investments in the forest sector [30]. Entre Ríos province in the northeast part of Argentina will likely see expanding afforested plantations because of the abundance of available fertile land, low land prices, mild climate, and the social acceptability of land owners to incorporate plantation forestry into their business models Forest plantations, however, can impact the environment by altering landscape structure and biological communities [31-34]. Birds, for example, were found to be lower in abundance and species richness in plantations compared to alternative land uses in the Entre Ríos region [31]. Insects, including native bees, were also negatively impacted by plantations, following a similar trend as bird communities (see Chapter 3).

In this region of rapidly expanding forestry plantations supported by government policies, we evaluated how multiple ES associated with current land uses will be impacted by afforested plantations. First, we developed a baseline LULC map for the region and then developed two alternative scenarios to illustrate impacts to ES. We considered a scenario that estimated the effects on ES based upon a major expansion of large-scale eucalyptus plantations, and a second scenario designed to match the expressed social values of the communities. Our objectives were to determine the potential trade-offs associated with plantation forestry in this region, and demonstrate the need to include the social dimension of sustainability in the expanding role of plantation forestry in Argentina.

\section{Methods}

There were three parts to our evaluation of ES and community values for this region. First, we created a baseline LULC map using 2013 satellite imagery, which served as the reference for comparing alterative scenarios. Second, we conducted interviews and surveys of the plantation communities to determine their values and support for eucalyptus expansion. Finally, we used GIS-based decision support tools to estimate and model ES under different scenarios of eucalyptus expansion using both primary and secondary data sources.

\section{Site description}

We conducted our work near Ubajay and La Criolla townships in Entre Ríos province in Argentina, approximately $400 \mathrm{~km}$ north of Buenos Aires (Fig. 1a and 1b). Both towns have eucalyptus (Eucalyptus spp.) plantations, though they differ in the spatial scale and landscape patterning. Ubajay township has 9 mills and large-scale plantations (>500 ha) 
while La Criolla township has one mill and smaller mixed-use farms with orchards, blueberries and pastures and only limited patches ( $<10$ ha each) of eucalyptus [30]. The province of Entre Rios is bordered by the Río Uruguay to the east and Río Paraná to the west, and is characterized by undulating low hills and rich loessoid or sandy soils. This region is part of the Pampas grassland, once one of the world's largest prairies, though most of the grasslands have been converted to cattle grazing and row crops [35]. Four common LULC types are present throughout this agriculturally dominated landscape: pasture for grazing that is intercropped with annual row crops (e.g. soy) making one effective LULC type (referred to as pasture/annual crops); large-scale forest plantations, mostly eucalyptus species but also pockets of pine (Pinus sp.) (referred to as plantations); small, family-owned mixed-use farms with citrus, blueberries and small patches of eucalyptus (10 ha or less) (mixed-use farms); and a native espinal savanna, an endemic habitat characterized by grassy plains with sparse, low stature xerophytic Acacia and Prosopis trees [36]. In this region, the majority of the landscape is pasture/annual crops, followed by plantations, espinal savanna and orchards.

\section{Baseline mapping}

To quantify the landscape-level land use patterns of the region, we created a LULC map using 30 m resolution 2013 USGS Landsat imagery and remote sensing and classification techniques. The baseline land use map was then ground-truthed with more than 200 random points. At each point, we documented the true land cover with a geo-referenced photo taken from a GPS-enabled smartphone, using either GPS Essential (Android) or Theodolite (Apple iOS) software applications. We then contrasted the predicted LULC with the actual observed photo using a confusion matrix approach and then retrained the QGIS remote sensing imaging software. Following our ground-truthing protocol, our 2013 base land cover map obtained 95\% accuracy for these common land cover types: pasture/annual crops, espinal, forest plantation and fruit/orchards. To facilitate later analysis for the ES modeling, we masked the roads, urban developments, and the region's waterways. This LULC map served as the baseline for comparison with alternative landuse scenarios that we developed (Fig. 1a and 1b).

\section{Community interviews and survey}

To assess community attitudes toward ES and the expansion of eucalyptus, we used a mix-method approach using both interviews and surveys. In 2014, we conducted 66 qualitative, open-ended, semi-structured interviews with predetermined questions for community members ( $45 \%$ female, $55 \%$ male) from both townships (31 respondents in Ubajay, 35 in La Criolla). Responses were then transcribed and evaluated using QSR International's NVivo 10 software that groups interview responses into larger themes and categories [30]. From this baseline knowledge, we devised a multi-part survey and asked respondents to score their responses on Likert scales. We returned in 2015 and randomly surveyed approximately 180 people ( 90 people in each community), asking respondents to identify ES they value, their support for government policies that promote eucalyptus 
expansion, and their priorities for nature conservation or economic development (Appendix 1-4). Most responses were measured on a 5-point Likert-type scale where $1=$ Totally Disagree, 5 = Totally Agree, and $3=$ Neutral; some questions were based upon a 7-point scale Likert, allowing for greater expression of nuance. Survey responses were summarized using SPSS (Sanders and Nelson, in preparation). Interviews and surveys were an extensive evaluations of the social communities in these townships, and only a portion of these data that directly relate to scenario development are reported here. (For complete interview questions and protocols, see Silva (2016).) After reviewing both the survey and interview responses, we synthesized the responses to create a future scenario land use map that reflected the values of these communities (described below). Interviewers and survey administrators completed Collaborative Institutional Training Initiative human subject protection training prior to conducting field research in the community, as directed by the Institutional Review Board of the University of Oregon.

\section{Scenario development ecosystem service evaluation}

We evaluated impacts to ecosystem services using Natural Capital Project InVEST (Integrated Valuation of Ecosystem Services and Tradeoffs) software modules (v. 3.3). InVEST is a spatially explicit, open-source software platform that calculates ecosystem service metrics based upon land-use maps and associated user-provided attributes We selected InVEST from the multiple ES models available because of its adaptability to user-provided local variables that could incorporate our field-based data [19]. These modules have been demonstrated to be robust and have been broadly validated in a variety of countries and habitats [25,37-39].

We used four InVEST tools to help evaluate ES in this region. First, we used the Scenario Generator, a program that can develop alternative land-use maps based upon usersupplied likelihoods of LULC transitions, percent change of land cover types, and other parameters. We created alternative scenarios that illustrated feasible (but not predictive) landscapes under different levels of eucalyptus expansion: (1) a major expansion of eucalyptus plantations, representing $200 \%$ increase in plantations (hereafter referred to as the EE scenario), and (2) a landscape that better reflects community values, as described in interviews and surveys results that we detail below (the CV scenario, henceforth). We considered pasture/annual crops to be the most likely land cover to be converted to plantations based upon expert interviews and observed changes in LULC in the past 10 years, where pastures were most often converted to plantations, seconded by fruit orchards, which have become less profitable in recent years. We prioritized the eastern portion of the study area for land conversion (closest to the Río Uruguay) from pasture to plantations because the western portion lacks mills, roads and related infrastructure to harvest and haul wood, has less than ideal soil types and has less history of plantation forestry. We inputted this likelihood of LULC to plantation by assigning probability weights from 0-1 where 1 makes a landscape the most likely to be converted and 0 prevents any conversion. We divided the study area using a constraining layer into three sections, with the eastern edge valued at 1 (most likely), the middle third at 0.75 and the western third at 0.5 (less likely) (Fig 2). For each LULC map created using the Scenario 
Generator, we applied InVEST (version 3.3) Carbon Sequestration, Pollination Service and Habitat Quality modules. We selected these ES because of their importance to the agriculture-dominated economy in Entre Ríos and based upon availability of our primary data and secondary data sources from literature.

The Pollination Service module produces two outputs: 1) an estimate of relative bee abundance based upon floral and nesting resources for each LULC type; and 2) a second index of relative pollination service from wild bees to crops, incorporating user-supplied bee species abundances and estimates of flight distance based upon size of the bee [40]. The bee abundance is expressed as a relative index from $0-1$, with 1 being the highest mean abundance. The pollination service index is also expressed from $0-1$. We used field-collected estimates for floral resources each LULC (Phifer, unpublished data) and interviewed INTA experts for nest resources to parameterize the model's LULC maps. We then incorporated the model with 33 wild species (or genus-level) bees that we previously had surveyed for in the region as well as estimates of their general flight distances based on bee size (see Chapter 4 for details on bees of this region; Appendix 5).

The Carbon Sequestration module sums total carbon from four pools of long-term carbon storage - above ground biomass, below ground biomass, soil carbon and dead woody debris - within a landscape and expresses it as a total of $\mathrm{Mg}$ of carbon per hectare. Values for the different carbon pool sources were provided from United Nations' Intergovernmental Panel on Climate Change report [41], field collected soil samples (M. Brill-Cisz, in preparation) or from relevant Argentine studies [42]; see Table 1 for carbon pool values. We assumed pasture/annual crops had zero carbon storage above ground since these LULC types are turned over too frequently to store carbon (i.e. cattle consume the grasses or the crops are harvested) [37].

We used the Habitat Quality module that calculates habitat suitability for user-supplied species for each LULC type. We used birds as a proxy for overall biodiversity, since we had previously surveyed the bird communities in each LULC in the region [31]. This module applies habitat quality estimates for each LULC type that range from 0 to 1 , with 1 being good habitat sufficient for foraging and reproduction and zero being not suitable. The model calculates the impact of possible threats these habitats and their sensitivity and resilience to change, using 0 to 1 . In our scenarios, we considered plantations a threat since it was shown to negatively impact avian biodiversity. Thus, because our focus us on the afforested plantations, we considered the expanded plantations from our LULC map and treated it as a threat in our future $\mathrm{CV}$ and EE scenarios.

Finally, each InVEST model produces a map to help visualize the spatial nature of ES and the LULC changes, in addition to model-specific attribute tables. As a way to contrast the different scenarios and the resulting changes in multiple ES, we summed each InVEST-based map for each scenario and ES to create single landscape-level score that we then represented as relative changes in ecosystem services in a single chart. 


\section{Results}

\section{Community interviews and survey}

Surveys and interviews suggest that they community is accepting of the eucalyptus plantations and understands the economic benefits and employment opportunities they provide. Survey data also revealed some hesitations and concerns about impacts from eucalyptus expansion, both to the communities and to the environment. While there were differences in survey responses between Ubajay and La Criolla, they were not statistically different and we pooled their responses together to create a broader pool that describes the general opinion of the community and its attitude towards the plantations.

From the survey, both communities ranked the same four ecosystem services and economic opportunities as being the most important to them: clean air, productive soils, clean and plentiful water, and economic opportunities (Table 3). Economic opportunities were identified as the first priority for both communities, however. Survey respondents expressed neutral support for government programs for further expansion of eucalyptus plantations, with a mean score of 3.1 out of 5 . Survey respondents also felt that the government does not do enough to adequately protect the environment and nature (mean of 2.87 out of 5), while believing that nature should be prioritized over the economy (mean of 5.95 out of 7 ).

Interviewees also reported perceived changes to ES associated with afforested plantations. For example, one person shared in an interview: "I've noticed that the majority of streams here...and the water sources have begun to decrease...where there are tree plantations the streams are dry," and another member retold a story: "My grandmother's land is in front of a tree plantation. As this tree plantation began to grow, the stream began to dry up. And it's at that point that you realize the impact it's having [on streams]" [30]. Community members valued nature in its many forms and saw the environment and human wellbeing as connected. For instance, one respondent stated "...the environment is important for good health and for everything..." [30]. Participants also noted that although the plantations were beautiful shades of green, some missed the past landscapes with unbroken views of the land, saying "Maybe I do not really enjoy such great sections of monoculture of eucalyptus and pine because one wants to see the horizon and never can because it's blocked by tree plantations, which are artificial..." Other interviewees noted the loss of the fruit industry, an important part of the local cultural identity for La Criolla that proclaims itself the blueberry and citrus capitol of Argentina: "Every day we are left with less and less of what we were before. They [producers in the community] are leaving because they sold their properties and they leave... most likely they produced citrus, but they quit producing citrus, sold [their property], and now other people own the land and they plant tree plantations" [30]. Lastly, respondents were acutely aware of the impact government policy has on the eucalyptus expansion with one respondent commenting, "As long as [eucalyptus] continues to be profitable, people will keep planting more eucalyptus because... there is global need [for wood products], [and] the Argentine state has subsidized tree plantations 
for many years. An Argentine producer can establish a tree plantation practically for free...” [30]

Using these expressed values, we designed a feasible CV scenario map that limited expansion of eucalyptus plantations to $100 \%$ above the 2013 baseline and increased fruit orchards by $50 \%$, reflecting one interpretation of the communities' desire to better balance the economic opportunities plantations may afford with concerns for continuing traditional ways of life, and valuing nature over exclusive economic returns. Reducing plantations also better represents people's general concern for biodiversity, water quantity and quality, and soil health, which plantations have been shown to change [4347]. This scenario also reflects the reservation expressed for the further government support for plantation expansion. The CV scenario is not intended to be a final answer to the question of social inclusion in natural resources management and planning, but instead a place to begin exploring how this landscape can better reflect the social values of these communities.

\section{Ecosystem service evaluation}

\section{Carbon sequestration}

The carbon sequestration model estimated 100,695,212 Mg of carbon for the whole study area in its baseline condition. In the EE scenario $150,785,323 \mathrm{Mg}$ of carbon were captured, mostly in the above and below ground carbon that the planted trees can store, nearly $50 \%$ more carbon than the baseline scenario. The CV scenario potentially stores $126,094,417 \mathrm{Mg}$ of carbon, reflecting the more limited expansion of eucalyptus and the growth of fruit orchards that store more above and below ground biomass carbon (Fig. 4).

\section{Pollination service}

Estimated bee abundance varied with each land use, shown in Fig. 5 as regional heatmaps that varied from a relative index of 0 to 0.64 across the study region, where 1 would be highest mean abundance. The poor-quality habitat of plantations (i.e., low floral and nesting resources in spring) reduced mean relative abundances compared to other land uses. In the $\mathrm{EE}$ and $\mathrm{CV}$ future scenarios considered, as plantations expanded, estimates of bee abundance declined across the study area. Pollination services were also estimated to decline with expanding plantations. The model, which considers the foraging range of bee species, estimated pollination service sinks in large monocultures of croplands that are far from nesting and floral resources. Fruit orchards in La Criolla, for example, adjacent to plantations were less likely to be visited by wild bees (Fig. 5).

\section{Habitat quality}

Habitat scores (the raw summation of the LULC values for each scenario) for birds changed with each scenario. The EE scenario resulted in a $25 \%$ decline in habitat quality 
compared to the baseline. The CV scenario was intermediate, with a $14 \%$ decline in habitat quality (Fig. 6). The greatest driver in the decline of habitat was the expansion of the plantations and the conversion of espinal and pasture to eucalyptus. The expansion of fruit orchards resulted in improved habitat for birds as well. These former LULC types support more birds than the relatively depopulated plantations.

\section{Discussion}

We considered the impacts of land-use change on three ES in Entre Ríos, Argentina, contrasting the effects of different degrees of eucalyptus plantation expansion. Relative pollination service and habitat quality declined as the eucalyptus expanded while carbon sequestration increased with plantation area compared to the current baseline (Fig. 7). Both in the interviews and survey, the communities acknowledged the trade-offs associated with expanding plantations, noting the economic benefits associated with plantations but also the loss of part of their cultural identity and potential impacts from the afforested plantations on soil, water and biodiversity. These results demonstrate the need to consider multiple ecosystem services and community preference when estimating the impact of land-use change on natural capital [48-50].

The carbon sequestration estimates linked growth in sequestration with plantation and orchard area. The greatest contributors to the net gains in carbon sequestration in the CV and EE scenarios were the above and below ground biomass pools. Estimates for carbon sequestration of the plantations depended upon the length of time between harvests; the longer the rotation, the more carbon that can be locked into the trunks and roots of the trees. In this region, eucalyptus trees are harvested between 12-15 years, depending on site quality before harvest. Trees are usually harvested and allowed to regrow, resulting in retention of most of the below ground carbon. However, shorter harvest rotations would limit the amount of carbon that is locked in the trees' stems. The carbon sequestration potential is also highly dependent upon the previous land use and the land management [46,51].

The InVEST Pollination model also predicted a decrease in native bee abundance and pollination service to crops with expanding plantations. This model has been demonstrated to be predictive in simple, homogenous landscapes similar to ours, with relatively large-scale agricultural fields and limited habitat heterogeneity or complexity $[52,53]$. The expansion eucalyptus plantations may result in the loss or displacement of this vital ES. Soy is the most common annual crop planted in this region, and although it is commonly thought to be self-pollinating, wild bees do forage on its flowers and proximity to forest and nature/semi-natural areas was shown to increase soy bean yields through increased visitation rates [54]. Small farmers in La Criolla that depend upon pollination for blueberry or citrus fruits (two pollinator dependent crops) benefit from more diverse landscapes that support higher floral resources and nesting habitats near their orchards. These small-scale mixed-use farms are often small enough for even smaller bees to visit flowering plants on the farm and nest in nearby fallow or underutilized lands. Wild bees also provide insurance against the loss of managed honey 
bees, and often provide greater pollination service than honey bees [55-57] Further, wild bees help support the broader diversity of plants in the region, providing an essential ecological interaction for biodiversity as a whole [58].

Afforested plantations represent a large structural change to a pasture/grassland landscape once the trees mature. This habitat change can impact avian communities that are ecological and evolutionarily accustomed to open grasslands. This region never supported tall trees, and the structural changes brought about from the plantations are likely perceived by many species as a "green wall" to be avoided. Avian biodiversity within the plantations was much lower compared to the surrounding LULC types, although bird abundance and diversity rebounded within $100 \mathrm{~m}$ of the plantation edge [31]. In northeast Argentina in Misiones province, tree plantations also negatively impacted avian diversity [59], though the results were less pronounced, likely because the alternative land use was a native forest that is structurally similar to tree plantations. The decrease in avian biodiversity and the simplification of the species pool may impact birddependent ecosystem services, such as pest control, seed dispersal and pollination $[60,61]$.

Our LULC map was made from 30 m resolution imagery, which can "average out" important fine-scale landscape characteristics. Recent work that compared the effects of 5 $\mathrm{m}$ and $30 \mathrm{~m}$ resolution using InVEST Carbon and Pollination modules found that although the trends were the same for both resolutions, finer resolution resulted in a more nuanced and detailed map that would allow for greater real-world application and management [62]. Particularly for pollinators, which operate on both landscape and local levels, floral resources can be "hidden" from coarser LULC maps. In our study region, for example, pockets of flowers existed within the plantation where gaps were present, usually as a result of a tree falling or die-back, that are not sensed at the landscape scale. Scale is also an important consideration for ES valuation, with some ES valued at national or global (e.g. carbon sequestration) levels and other ES at a regional or local scale (e.g. pollination). Considering the scale of the beneficiaries is essential when considering locally relevant land-use planning and management $[21,23,50]$.

Land-use changes, including plantation forestry, will likely continue to increase in the Entre Rios region because of favorable government policies. As one respondent said, these plantations are practically "free." The "free" plantation is the result of the subsidies provided under the Argentine Plantation Investment Law. However, in 2018 this legislation will need to be reauthorized by the Argentine government, making this a ripe time to consider the potential tradeoffs with plantation expansions and consider ways to maximize the benefits and minimize the loss of ecosystem services.

Our work should be carefully considered and evaluated before policy renewals. The scenarios we developed are not predictions, but rather are illustrations of possible landscapes and estimates of the impacts on ES. InVEST modules are static, representing one moment in time, and do not fully capture seasonal or year-over-year changes or changes in government policy, market conditions or social values that may reflect land- 
use preferences in the future. We recommend sharing this research and ES-based maps with the communities we surveyed to report our results, but also to hear from members themselves their thoughts, particularly, their views on the CV scenario we generated from the interviews and survey results. Scenario development is a critical tool for land management and planning, and it should be an iterative process, with results shared, incorporated and community input integrated into recommendations [26].

\section{Acknowledgements}

This research was supported by the National Science Foundation Partnerships for International Research and Education program (grant num. 124344), USDA McIntireStennis Program and MTU Graduate School Finishing Fellowship. The authors are deeply appreciative to the INTA extension agents, particularly L. Roman, who helped to build connections the many land owners who permitted us to conduct ecological sampling on their lands. We are indebted to the many people of Entre Ríos who spoke with us for the interviews and completed our surveys. We also thank all the landowners who allowed us to conduct on their lands in the region. We further thank the employees of staff of the INTA Concordia Research Station, where we based our research from. Lastly, we thank the anonymous reviewers whose comments helped improve earlier drafts of this manuscript prior to publication.

\section{Literature cited}

1. Tilman, D.; Balzer, C.; Hill, J.; Befort, B. L. Global food demand and the sustainable intensification of agriculture. Proc. Natl. Acad. Sci. U.S.A. 2011, 108, 20260-20264.

2. Cardinale, B. J.; Duffy, J. E.; Gonzalez, A.; Hooper, D. U.; Perrings, C.; Venail, P.; Narwani, A.; Mace, G. M.; Tilman, D.; Wardle, D. A.; Kinzig, A. P.; Daily, G. C.; Loreau, M.; Grace, J. B.; Larigauderie, A.; Srivastava, D. S.; Naeem, S. Biodiversity loss and its impact on humanity. Nature 2012, 486, 59-67.

3. Foley, J. A.; DeFries, R.; Asner, G. P.; Barford, C.; Bonan, G.; Carpenter, S. R.; Chapin, F. S.; Coe, M. T.; Daily, G. C.; Gibbs, H. K.; Helkowski, J. H.; Holloway, T.; Howard, E. A.; Kucharik, C. J.; Monfreda, C.; Patz, J. A.; Prentice, I. C.; Ramankutty, N.; Snyder, P. K. Global Consequences of Land Use. Science 2005, 309, 570-574.

4. Newbold, T.; Hudson, L. N.; Hill, S. L. L.; Contu, S.; Lysenko, I.; Senior, R. A.; Börger, L.; Bennett, D. J.; Choimes, A.; Ben Collen; Day, J.; De Palma, A.; Díaz, S.; Echeverria-Londoño, S.; Edgar, M. J.; Feldman, A.; Garon, M.; Harrison, M. L. K.; Alhusseini, T.; Ingram, D. J.; Itescu, Y.; Kattge, J.; Kemp, V.; Kirkpatrick, L.; Kleyer, M.; Correia, D. L. P.; Martin, C. D.; Meiri, S.; Novosolov, M.; Pan, Y.; Phillips, H. R. P.; Purves, D. W.; Robinson, A.; Simpson, J.; Tuck, S. L.; Weiher, E.; White, H. J.; Ewers, R. M.; Mace, G. M.; Scharlemann, J. P. W.; Purvis, A. Global effects of land use on local terrestrial biodiversity. Nature 2015, 520, 45-50. 
5. Dirzo, R.; Young, H. S.; Galetti, M.; Ceballos, G.; Isaac, N. J. B.; Collen, B.

Defaunation in the Anthropocene. Science 2014, 345, 401-406.

6. Dirzo, R.; Raven, P. H. Global State of Biodiversity and Loss. Annu. Rev. Environ. Resour. 2003, 28, 137-167.

7. Warman, R. D. Global wood production from natural forests has peaked. Biodivers Conserv 2014, 23, 1063-1078.

8. Paquette, A.; Messier, C. The role of plantations in managing the world's forests in the Anthropocene. Frontiers in Ecology and the Environment 2010, 8, $27-34$.

9. Payn, T.; Carnus, J.-M.; Freer-Smith, P.; Kimberley, M.; Kollert, W.; Liu, S.; Orazio, C.; Rodriguez, L.; Silva, L. N.; Wingfield, M. J. Changes in planted forests and future global implications. Forest Ecology and Management 2015, 352, 57-67.

10. Sloan, S.; Sayer, J. A. Forest Resources Assessment of 2015 shows positive global trends but forest loss and degradation persist in poor tropical countries. Forest Ecology and Management 2015, 352, 134-145.

11. Iversen, P. Forests' role in the climate change agenda. Unasylva 2016, 67, 3-11.

12. Assessment, M. E. Ecosystems and human well-being: Synethesis report. 2005, 1155.

13. Dobbs, C.; Escobedo, F. J.; Zipperer, W. C. A framework for developing urban forest ecosystem services and goods indicators. Landscape and Urban Planning 2011, 99, 196206.

14. Martínez, M. L.; Pérez-Maqueo, O.; Vázquez, G.; Castillo-Campos, G.; GarcíaFranco, J.; Mehltreter, K.; Equihua, M.; Landgrave, R. Effects of land use change on biodiversity and ecosystem services in tropical montane cloud forests of Mexico. Forest Ecology and Management 2009, 258, 1856-1863.

15. Kareiva, P. Natural capital: theory and practice of mapping ecosystem services; 2011.

16. Carpenter, S. R.; Mooney, H. A.; Agard, J.; Capistrano, D.; DeFries, R. S.; Díaz, S.; Dietz, T.; Duraiappah, A. K.; Oteng-Yeboah, A.; Pereira, H. M.; Perrings, C.; Reid, W. V.; Sarukhan, J.; Scholes, R. J.; Whyte, A. Science for managing ecosystem services: Beyond the Millennium Ecosystem Assessment. Proc Natl Acad Sci USA 2009, 106, 1305-1312.

17. Raudsepp-Hearne, C.; Peterson, G. D.; Bennett, E. M. Ecosystem service bundles for analyzing tradeoffs in diverse landscapes. Proc. Natl. Acad. Sci. U.S.A. 2010, 107, 52425247. 
18. Bagstad, K. J.; Semmens, D. J.; Winthrop, R. Comparing approaches to spatially explicit ecosystem service modeling: a case study from the San Pedro River, Arizona. Ecosyst. Serv. 5, e40ee50; 2013.

19. Bagstad, K. J.; Semmens, D. J.; Waage, S.; Winthrop, R. A comparative assessment of decision-support tools for ecosystem services quantification and valuation. Ecosystem Services, 1-13; 2013.

20. Bennett, E. M.; Peterson, G. D.; Gordon, L. J. Understanding relationships among multiple ecosystem services. Ecology Letters 2009, 12, 1394-1404.

21. Posner, S. M.; Verutes, G.; Koh, I.; Denu, D.; Ricketts, T. Global use of ecosystem service models. Ecosystem Services 2016, 17, 131-141.

22. Posner, S. M.; Getz, C.; Ricketts, T. Evaluating the impact of ecosystem service assessments on decision-makers. Environmental Science and Policy 2016, 64, 30-37.

23. McKenzie, E.; Posner, S. M.; Tillmann, P.; Bernhardt, J. R.; Howard, K.; Rosenthal, A. Understanding the Use of Ecosystem Service Knowledge in Decision Making: Lessons from International Experiences of Spatial Planning. Environment and Planning C: Government and Policy 2014, 32, 320-340.

24. Mahmoud, M.; Liu, Y.; Hartmann, H.; Stewart, S.; Wagener, T.; Semmens, D.; Stewart, R.; Gupta, H.; Dominguez, D.; Dominguez, F.; Hulse, D.; Letcher, R.; Rashleigh, B.; Smith, C.; Street, R.; Ticehurst, J.; Twery, M.; van Delden, H.; Waldick, R.; White, D.; Winter, L. A formal framework for scenario development in support of environmental decision-making. Environmental Modelling and Software 2009, 24, 798808.

25. Arkema, K. K.; Verutes, G. M.; Wood, S. A.; Clarke-Samuels, C.; Rosado, S.; Canto, M.; Rosenthal, A.; Ruckelshaus, M.; Guannel, G.; Toft, J.; Faries, J.; Silver, J. M.; Griffin, R.; Guerry, A. D. Embedding ecosystem services in coastal planning leads to better outcomes for people and nature. Proc. Natl. Acad. Sci. U.S.A. 2015, 112, 73907395.

26. McKenzie, E.; Rosenthal, A. Developing Scenarios to Assess Ecosystem Service Tradeoffs; 2012; pp. 1-132.

27. Podolak, K.; Lowe, E.; Wolny, S.; Nickel, B.; Kelsey, R. Informing watershed planning and policy in the Truckee River basin through stakeholder engagement, scenario development, and impact evaluation. Environmental Science and Policy 2017, 69, 124135.

28. Pretty, J.; Smith, D. Social Capital in Biodiversity Conservation and Management. Conservation Biology 2004, 18, 631-638. 
29. Verutes, G. M.; Arkema, K. K.; Clarke-Samuels, C.; Wood, S. A.; Rosenthal, A.; Rosado, S.; Canto, M.; Bood, N.; Ruckelshaus, M. Integrated planning that safeguards ecosystems and balances multiple objectives in coastal Belize. International Journal of Biodiversity Science, Ecosystem Services \& Management 2017, 13, 1-17.

30. Silva, C. Community perceptions of ecosystem services and human well-being from tree plantations in Argentina, Flagstaff, AZ, 2016.

31. Phifer, C. C.; Knowlton, J. L.; Webster, C. R.; Flaspohler, D. J.; Licata, J. A. Bird community responses to afforested eucalyptus plantations in the Argentine pampas. Biodivers Conserv 2016, 79, 1-29.

32. Brockerhoff, E. G.; Jactel, H.; Parrotta, J. A.; Ferraz, S. F. B. Role of eucalypt and other planted forests in biodiversity conservation and the provision of biodiversity-related ecosystem services. Forest Ecology and Management 2013, 301, 43-50.

33. Nosetto, M. D.; Jobbágy, E. G.; Paruelo, J. M. Land-use change and water losses: the case of grassland afforestation across a soil textural gradient in central Argentina. Global Change Biol 2005, 11, 1101-1117.

34. Vihervaara, P.; Marjokorpi, A.; Kumpula, T.; Walls, M.; Kamppinen, M. Ecosystem services of fast-growing tree plantations: A case study on integrating social valuations with land-use changes in Uruguay. Forest Policy and Economics 2012, 14, 58-68.

35. Medan, D.; Torretta, J. P.; Hodara, K.; la Fuente, de, E. B.; Montaldo, N. H. Effects of agriculture expansion and intensification on the vertebrate and invertebrate diversity in the Pampas of Argentina. Biodivers Conserv 2011, 20, 3077-3100.

36. Lewis, J. P.; Noetinger, S.; Prado, D. E.; Barberis, I. M. Woody vegetation structure and composition of the last relicts of Espinal vegetation in subtropical Argentina.

Biodivers Conserv 2009, 18, 3615-3628.

37. Goldstein, J. H.; Caldarone, G.; Duarte, T. K. Integrating ecosystem-service tradeoffs into land-use decisions. In; 2012.

38. Nelson, E.; Mendoza, G.; Regetz, J.; Polasky, S.; Tallis, H.; Cameron, D.; Chan, K. M.; Daily, G. C.; Goldstein, J.; Kareiva, P. M.; Lonsdorf, E.; Naidoo, R.; Ricketts, T. H.; Shaw, M. Modeling multiple ecosystem services, biodiversity conservation, commodity production, and tradeoffs at landscape scales. Frontiers in Ecology and the Environment 2009, 7, 4-11.

39. Mushet, D. M.; Neau, J. L.; Euliss, N. H., Jr Modeling effects of conservation grassland losses on amphibian habitat. Biological Conservation 2014, 174, 93-100.

40. Lonsdorf, E.; Kremen, C.; Ricketts, T.; Winfree, R.; Williams, N.; Greenleaf, S. Modelling pollination services across agricultural landscapes. Annals of Botany 2009, 
$103,1589-1600$.

41. IPCC. Climate Change 2014: Synthesis Report. Contribution of Working Groups I, II and III to the Fifth Assessment Report of the Intergovernmental Panel on Climate Change; Pachauri, R. K.; Meyer, L. A., Eds.; IPCC: Geneva, Switzerland, 2014; pp. 1169.

42. Gonzalez-Roglich, M.; Swenson, J. J.; Jobbágy, E. G.; Jackson, R. B. Shifting carbon pools along a plant cover gradient in woody encroached savannas of central Argentina. Forest Ecology and Management 2014, 331, 71-78.

43. Bremer, L. L.; Farley, K. A. Does plantation forestry restore biodiversity or create green deserts? A synthesis of the effects of land-use transitions on plant species richness. Biodivers Conserv 2010, 19, 3893-3915.

44. Farley, K. A.; Jobbágy, E. G.; Jackson, R. B. Effects of afforestation on water yield: a global synthesis with implications for policy. Global Change Biol 2005, 11, 1565-1576.

45. Eclesia, R. P.; Jobbágy, E. G.; Jackson, R. B.; Biganzoli, F.; Piñeiro, G. Shifts in soil organic carbon for plantation and pasture establishment in native forests and grasslands of South America. Global Change Biol 2012, 18, 3237-3251.

46. Berthrong, S. T.; Jobbágy, E. G.; Jackson, R. B. A global meta-analysis of soil exchangeable cations, $\mathrm{pH}$, carbon, and nitrogen with afforestation. Ecological Applications 2009, 19, 2228-2241.

47. Six, L. J.; Bakker, J. D.; Bilby, R. E. Vegetation dynamics in a novel ecosystem: agroforestry effects on grassland vegetation in Uruguay. Ecosphere 2014, 5, art74-15.

48. Viglizzo, E. F.; Paruelo, J. M.; Laterra, P.; Jobbágy, E. G. Ecosystem service evaluation to support land-use policy. "Agriculture, Ecosystems and Environment" 2012, $154,78-84$.

49. Schirmer, J.; Bull, L. Assessing the likelihood of widespread landholder adoption of afforestation and reforestation projects. Global Environmental Change 2014, 24, 306320.

50. Howe, C.; Suich, H.; Vira, B.; Mace, G. M. Creating win-wins from trade-offs? Ecosystem services for human well-being: A meta-analysis of ecosystem service tradeoffs and synergies in the real world. Global Environmental Change 2014, 28, 263-275.

51. Pauli, N.; Donough, C.; Oberthür, T.; Cock, J.; Verdooren, R.; Rahmadsyah; Abdurrohim, G.; Indrasuara, K.; Lubis, A.; Dolong, T.; Pasuquin, J. M. Changes in soil quality indicators under oil palm plantations following application of "best management practices" in a four-year field trial. "Agriculture, Ecosystems and Environment" 2014, $195,98-111$. 
52. Kennedy, C. M.; Lonsdorf, E.; Neel, M. C.; Williams, N. M.; Ricketts, T. H.; Winfree, R.; Bommarco, R.; Brittain, C.; Burley, A. L.; Cariveau, D.; Carvalheiro, L. G.; Chacoff, N. P.; Cunningham, S. A.; Danforth, B. N.; Dudenhöffer, J.-H.; Elle, E.; Gaines, H. R.; Garibaldi, L. A.; Gratton, C.; Holzschuh, A.; Isaacs, R.; Javorek, S. K.; Jha, S.; Klein, A. M.; Krewenka, K.; Mandelik, Y.; Mayfield, M. M.; Morandin, L.; Neame, L. A.; Otieno, M.; Park, M.; Potts, S. G.; Rundlöf, M.; Sáez, A.; Steffan-Dewenter, I.; Taki, H.; Viana, B. F.; Westphal, C.; Wilson, J. K.; Greenleaf, S. S.; Kremen, C. A global quantitative synthesis of local and landscape effects on wild bee pollinators in agroecosystems. Ecology Letters 2013, 16, 584-599.

53. Lonsdorf, E.; Kremen, C.; Ricketts, T.; Winfree, R.; Williams, N.; Greenleaf, S. Modelling pollination services across agricultural landscapes. Annals of Botany 2009, $103,1589-1600$.

54. Monasterolo, M.; L, M. M.; R, V. G.; A, S. Soybean crops may benefit from forest pollinators. "Agriculture, Ecosystems and Environment" 2015, 202, 217-222.

55. Winfree, R.; Williams, N. M.; Dushoff, J.; Kremen, C. Native bees provide insurance against ongoing honey bee losses. Ecology Letters 2007, 10, 1105-1113.

56. Garibaldi, L. A.; Steffan-Dewenter, I.; Winfree, R.; Aizen, M. A.; Bommarco, R.; Cunningham, S. A.; Kremen, C.; Carvalheiro, L. G.; Harder, L. D.; Afik, O.; Bartomeus, I.; Benjamin, F.; Boreux, V.; Cariveau, D.; Chacoff, N. P.; Dudenhöffer, J. H.; Freitas, B. M.; Ghazoul, J.; Greenleaf, S.; Hipólito, J.; Holzschuh, A.; Howlett, B.; Isaacs, R.; Javorek, S. K.; Kennedy, C. M.; Krewenka, K. M.; Krishnan, S.; Mandelik, Y.; Mayfield, M. M.; Motzke, I.; Munyuli, T.; Nault, B. A.; Otieno, M.; Petersen, J.; Pisanty, G.; Potts, S. G.; Rader, R.; Ricketts, T. H.; Rundlöf, M.; Seymour, C. L.; Schüepp, C.; Szentgyörgyi, H.; Taki, H.; Tscharntke, T.; Vergara, C. H.; Viana, B. F.; Wanger, T. C.; Westphal, C.; Williams, N.; Klein, A. M. Wild Pollinators Enhance Fruit Set of Crops Regardless of Honey Bee Abundance. Science 2013, 339, 1608-1611.

57. Garibaldi, L. A.; Carvalheiro, L. G.; Vaissière, B. E.; Gemmill-Herren, B.; Hipólito, J.; Freitas, B. M.; Ngo, H. T.; Azzu, N.; Sáez, A.; Åström, J.; An, J.; Blochtein, B.; Buchori, D.; García, F. J. C.; da Silva, F. O.; Devkota, K.; de Fátima Ribeiro, M.; Freitas, L.; Gaglianone, M. C.; Goss, M.; Irshad, M.; Kasina, M.; Filho, A. J. S. P.; Kiill, L. H. P.; Kwapong, P.; Parra, G. N.; Pires, C.; Pires, V.; Rawal, R. S.; Rizali, A.; Saraiva, A. M.; Veldtman, R.; Viana, B. F.; Witter, S.; Zhang, H. Mutually beneficial pollinator diversity and crop yield outcomes in small and large farms. Science 2016, 351, 388-391.

58. Soliveres, S.; van der Plas, F.; Manning, P.; Prati, D.; Gossner, M. M.; Renner, S. C.; Alt, F.; Arndt, H.; Baumgartner, V.; Binkenstein, J.; Birkhofer, K.; Blaser, S.; Blüthgen, N.; Boch, S.; Böhm, S.; Börschig, C.; Buscot, F.; Diekötter, T.; Heinze, J.; Hölzel, N.; Jung, K.; Klaus, V. H.; Kleinebecker, T.; Klemmer, S.; Krauss, J.; Lange, M.; Morris, E. K.; Müller, J.; Oelmann, Y.; Overmann, J.; Pašalić, E.; Rillig, M. C.; Schaefer, H. M.; Schloter, M.; Schmitt, B.; Schöning, I.; Schrumpf, M.; Sikorski, J.; Socher, S. A.; Solly, E. F.; Sonnemann, I.; Sorkau, E.; Steckel, J.; Steffan-Dewenter, I.; Stempfhuber, B.; 
Tschapka, M.; Türke, M.; Venter, P. C.; Weiner, C. N.; Weisser, W. W.; Werner, M.; Westphal, C.; Wilcke, W.; Wolters, V.; Wubet, T.; Wurst, S.; Fischer, M.; Allan, E. Biodiversity at multiple trophic levels is needed for ecosystem multifunctionality. Nature Publishing Group 2016, 536, 456-459.

59. Zurita, G. A.; Rey, N.; Varela, D. M.; Villagra, M.; Bellocq, M. I. Conversion of the Atlantic Forest into native and exotic tree plantations: Effects on bird communities from the local and regional perspectives. Forest Ecology and Management 2006, 235, 164173.

60. Wenny, D. G.; DeVault, T. L.; Johnson, M. D.; Kelly, D.; H Sekercioglu, C.;

Tomback, D. F.; Whelan, C. J. The Need to Quantify Ecosystem Services Provided by Birds. The Auk 2011, 128, 1-14.

61. Sekercioglu, C. H. Bird functional diversity and ecosystem services in tropical forests, agroforests and agricultural areas. J Ornithol 2012, 153, 153-161.

62. Grafius, D. R.; Corstanje, R.; Warren, P. H.; Evans, K. L.; Hancock, S.; Harris, J. A. The impact of land use/land cover scale on modelling urban ecosystem services.

Landscape Ecol 2016, 31, 1509-1522.

\section{Tables}

Table 1: Sources of carbon pools $\left(\mathrm{Mg} \mathrm{ha}^{-1}\right)$ for each LULC type that were used for Carbon Sequestration InVEST module for Entre Ríos, Argentina.

\begin{tabular}{lccccl}
\hline \multicolumn{1}{c}{ LULC } & $\begin{array}{c}\text { Above } \\
\text { ground }\end{array}$ & $\begin{array}{c}\text { Below } \\
\text { ground }\end{array}$ & Soil & $\begin{array}{c}\text { Dead } \\
\text { organic } \\
\text { matter }\end{array}$ & \multicolumn{1}{c}{ Sources } \\
\hline Fruit & 60 & 18 & 61.7 & 0 & IPCC \\
Pasture/crops & 0 & 0 & 61.7 & 0 & IPCC \\
Espinal & 11 & 2.42 & 60.2 & .5 & 2014 \\
Savanna & 140 & 46.2 & 30.8 & 0 & M. Brill-Cisz; IPCC \\
Plantations & & & & &
\end{tabular}


Table 2: Floral and nesting resources each LULC type that were used for Pollination Service InVEST module for Entre Ríos, Argentina. Estimates are an index from 0-1 where 0 is unavailable and 1 is abundant and available.

\begin{tabular}{lccccc}
\hline & \multicolumn{3}{c}{ Nest type availability } & \multicolumn{2}{c}{ Floral resources } \\
\multicolumn{1}{c}{ Larly } & & \\
LuLC & Cavity & Soil & Wood & spring & Late spring \\
\hline Fruit & 0.5 & 0.5 & 0.5 & 1 & 0.8 \\
Pasture/crops & 0.2 & 0.2 & 0 & 0.3 & 0.3 \\
Espinal & & & & & \\
savanna & 1 & 0.8 & 1 & 0.6 & 0.6 \\
Plantations & 0.1 & 0.2 & 0.3 & 0.1 & 0.2
\end{tabular}

Table 3. Responses from community members for the following questions: How important are the following aspects of the nature around them both for you and for your home? $\mathrm{N}$ is the number of people who answered the question and the mean Likert value. Bolded values represent top-five ES valued. Scores were based for Likert 1-5 scale, where 1 means "none" and 5 means "a lot."

\begin{tabular}{lcccc}
\hline & \multicolumn{2}{c}{ Ubajay } & \multicolumn{2}{c}{ La Criolla } \\
& $\mathrm{N}$ & Mean $( \pm \mathrm{SE})$ & $\mathrm{N}$ & Mean $( \pm \mathrm{SE})$ \\
\hline Attractive scenery & 86 & $4.50(.715)$ & 94 & $4.44(.665)$ \\
Recreation & 83 & $4.31(.697)$ & 93 & $4.48(.583)$ \\
Clean air & $\mathbf{8 5}$ & $\mathbf{4 . 8 5}(.362)$ & $\mathbf{9 4}$ & $\mathbf{4 . 8 5}(.387)$ \\
Clean water & $\mathbf{8 3}$ & $\mathbf{4 . 8 0}(. \mathbf{4 3 5})$ & $\mathbf{9 4}$ & $\mathbf{4 . 6 9}(.688)$ \\
Food & 81 & $4.56(.806)$ & 93 & $4.55(.700)$ \\
Economic opportunities & $\mathbf{8 5}$ & $\mathbf{4 . 7 6}(.648)$ & $\mathbf{9 3}$ & $\mathbf{4 . 6 1}(.643)$ \\
Bird habitat & 83 & $4.52(.571)$ & 93 & $4.49(.775)$ \\
Lots of water & $\mathbf{8 2}$ & $\mathbf{4 . 7 2}(.528)$ & $\mathbf{9 3}$ & $\mathbf{4 . 6 2}(.624)$ \\
Productive soils & $\mathbf{8 4}$ & $\mathbf{4 . 7 4}(. \mathbf{4 6 9})$ & $\mathbf{9 4}$ & $\mathbf{4 . 7 8}(.419)$
\end{tabular}


Table 4. Responses from community members for the following questions relating to policy and government responsivness. $\mathrm{N}$ is the number of people who answered the question and the mean Likert value. Scores were based for Likert 1-5 scale, where 1 means "none" and 5 means "a lot."

\begin{tabular}{lcccc} 
& \multicolumn{2}{c}{$\begin{array}{c}\text { Ubajay } \\
\text { Mean }( \pm \mathrm{SE})\end{array}$} & $\mathrm{N}$ & $\begin{array}{c}\text { La Criolla } \\
\text { Mean }( \pm \mathrm{SE})\end{array}$ \\
\hline $\begin{array}{l}\text { Government influence on } \\
\text { eucalyptus expansion }\end{array}$ & 75 & $3.05(1.218)$ & 78 & $3.26(1.062)$ \\
$\begin{array}{l}\text { Government promotion expansion } \\
\text { of eucalyptus }\end{array}$ & 84 & $3.40(1.152)$ & 88 & $3.10(1.287)$ \\
$\begin{array}{l}\text { The government protects the } \\
\text { environment }\end{array}$ & 87 & $2.48(1.170)$ & 87 & $2.62(1.164)$ \\
$\begin{array}{l}\text { The government responds to } \\
\text { community needs }\end{array}$ & 88 & $2.76(1.145)$ & 91 & $2.87(1.087)$
\end{tabular}




\section{Figures}
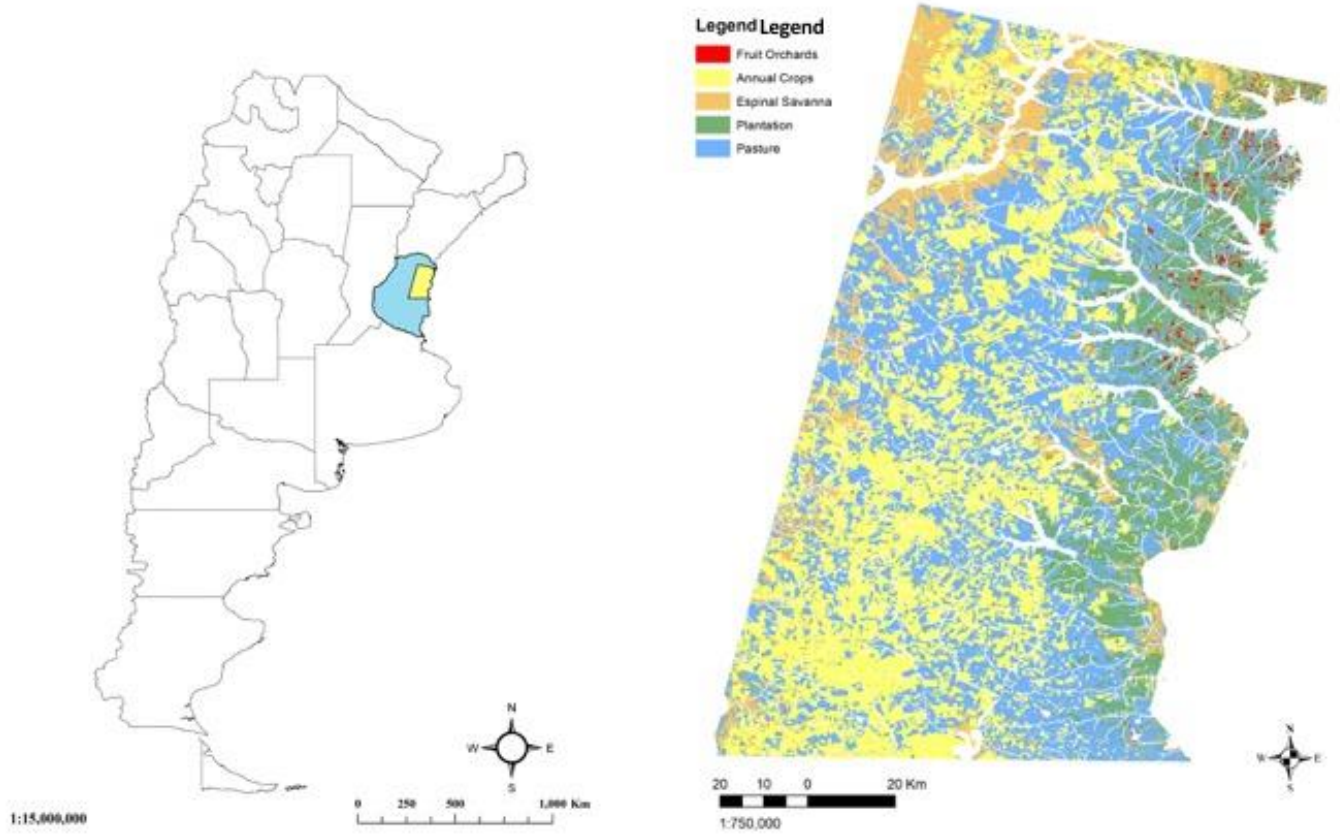

Fig. 1a and b. The left panel shows a map of Argentina and Entre Rios province (blue) with the study area shown in yellow. The right panel shows the study area and the common last use/land cover types in the area. 


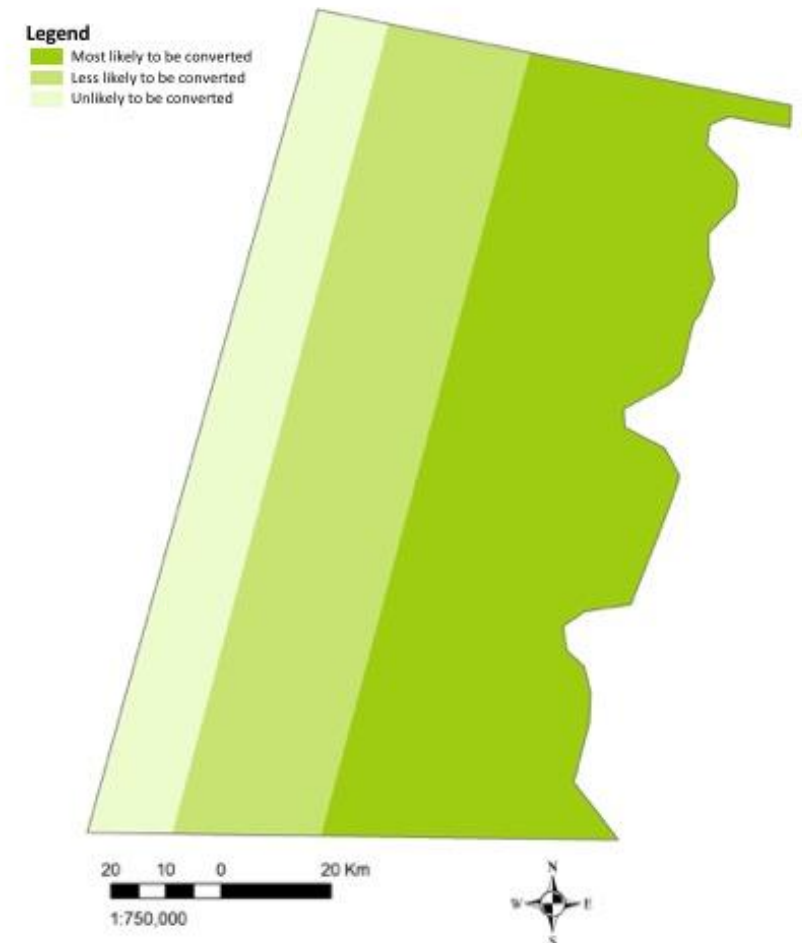

Fig. 2. Land-use change to eucalyptus plantation was weighted from most likely to unlikely using a constraining layer in the InVEST Scenario Generator model. Darker green areas were more likely to be converted to plantations while lighter green areas were less likely. These delineated lines are an approximation of biophysical limits, existing infrastructure and social acceptability of plantations. 


\section{Baseline}

$\infty$

\section{Community Values}

$100 \%$ increase in plantations

$50 \%$ in fruit

\section{Eucalyptus Expansion}

$200 \%$ increase in plantations
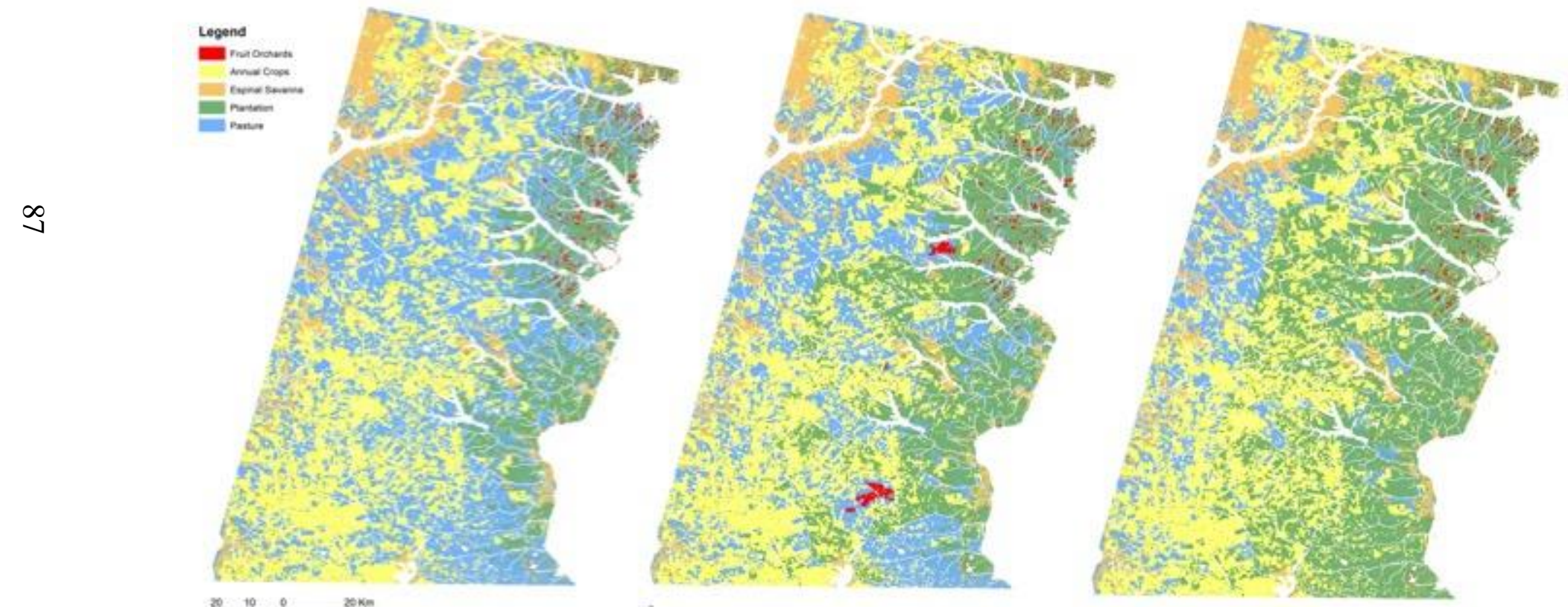

$=\sum_{1 \rightarrow 0000}^{10}$

Fig.3. Maps of the LULC under baseline, community values and eucalyptus expansion scenarios. 
Baseline

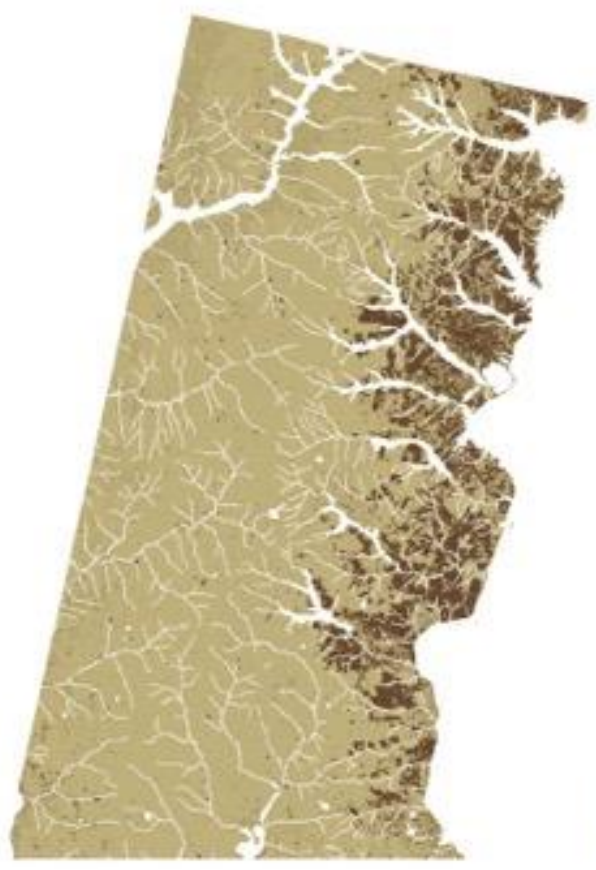

Community Values

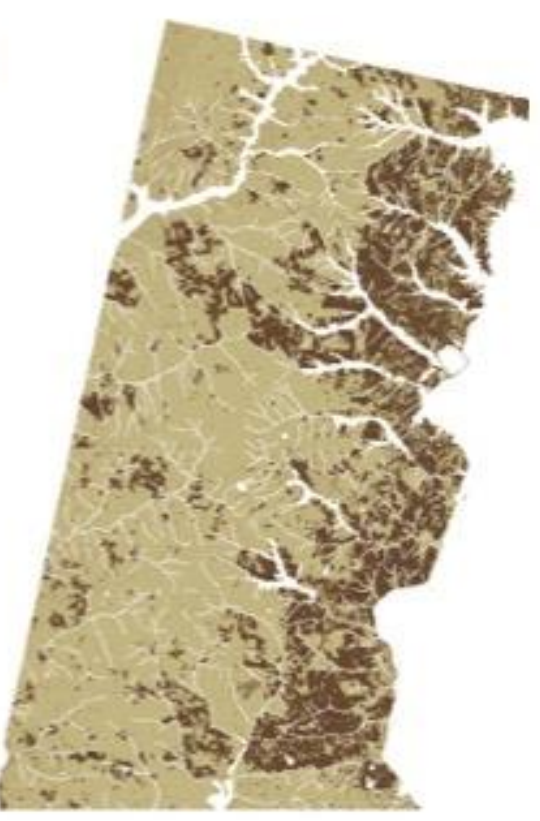

Eucalyptus Expansion

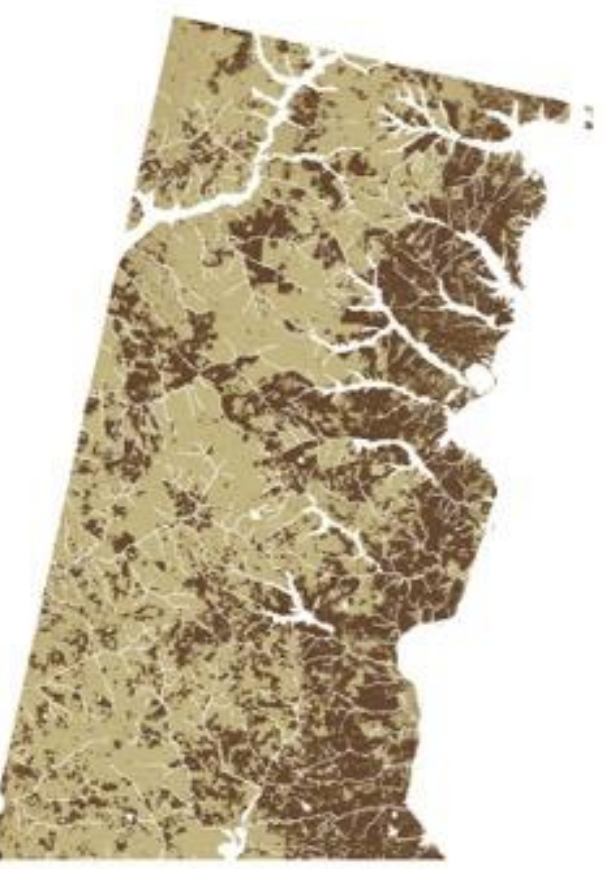

Fig.4. Carbon sequestration under baseline, community values and eucalyptus expansion scenarios. Darker brown indicates higher carbon sequestration potential. 
Baseline

$\infty$

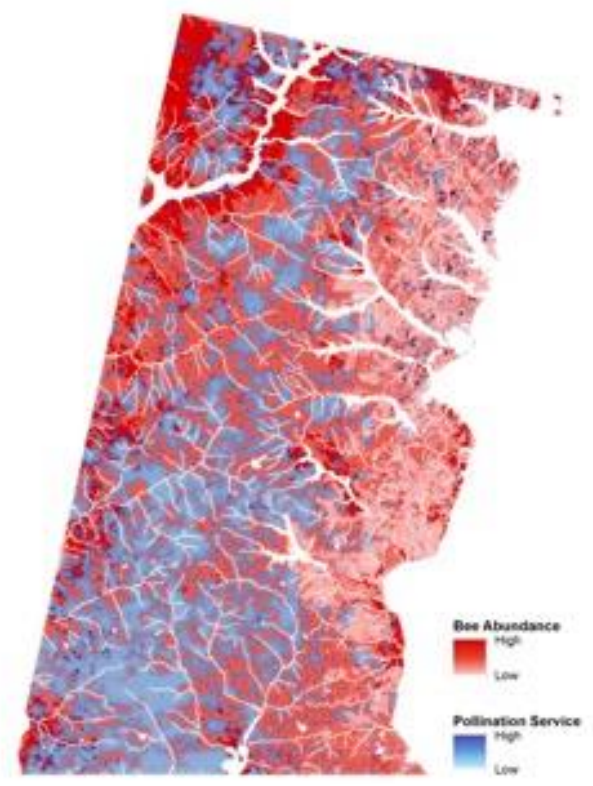

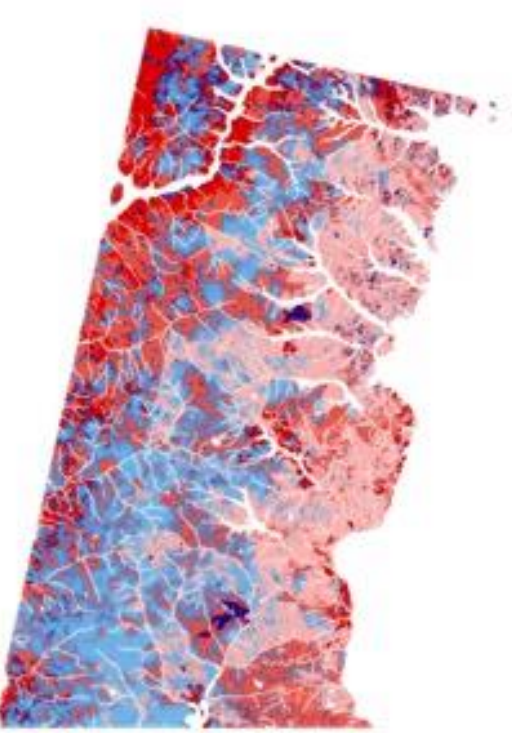

Eucalyptus Expansion

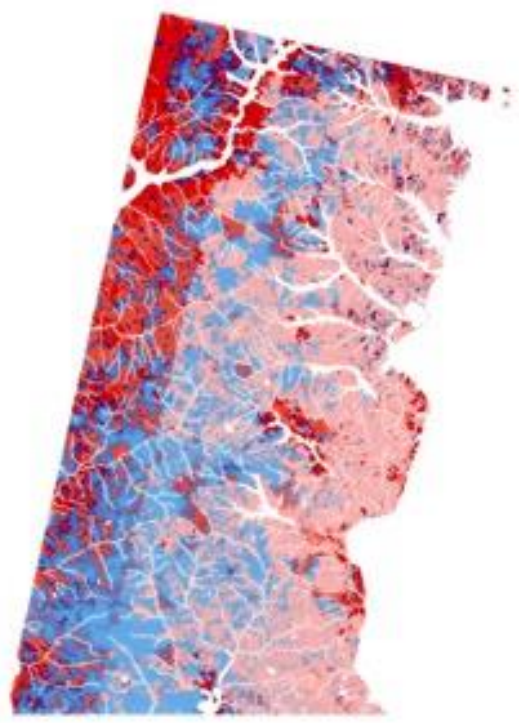

Fig. 5. Maps of the potential bee abundance and pollination service under baseline, community values and eucalyptus expansion scenarios. Darker shades of red indicate higher mean bee abundance. Dark blue indicates higher pollination service. 
Baseline

8
Community Values

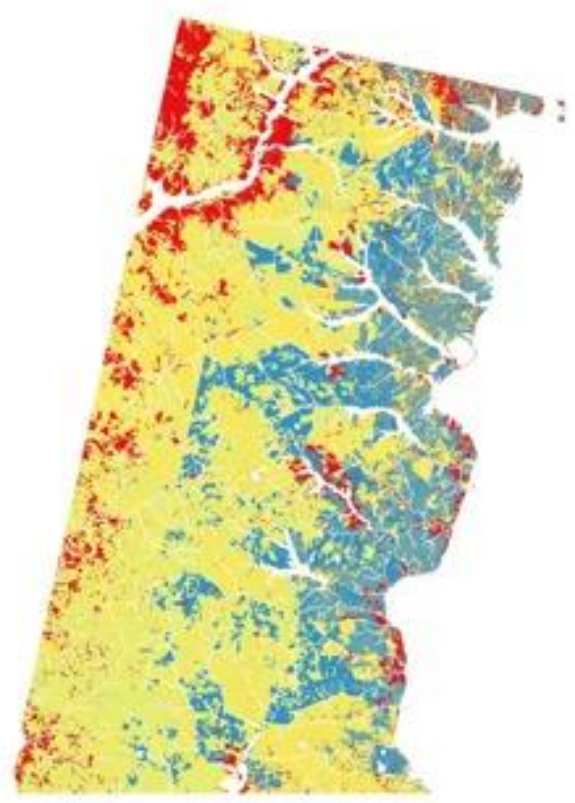

Eucalyptus Expansion

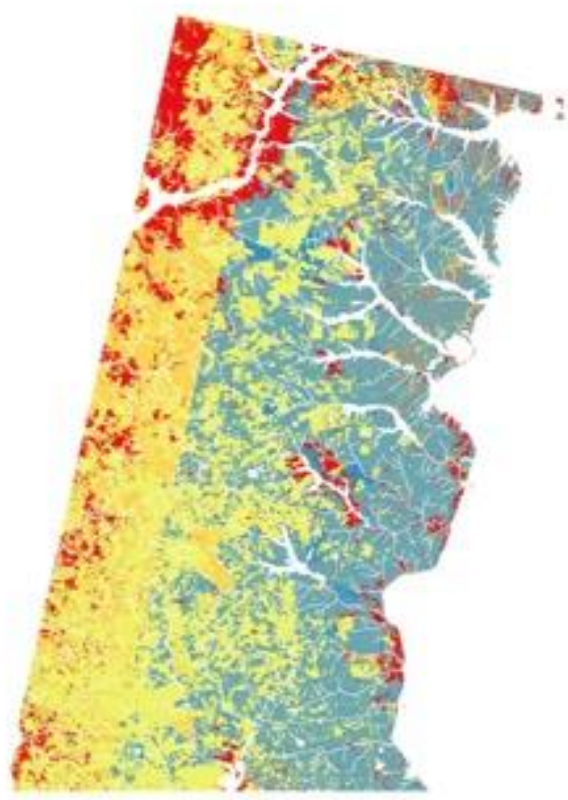

Fig. 6. Maps of avian habitat quality. Warmer shades indicate higher quality habitat; cooler shades represent lower quality habitats. 


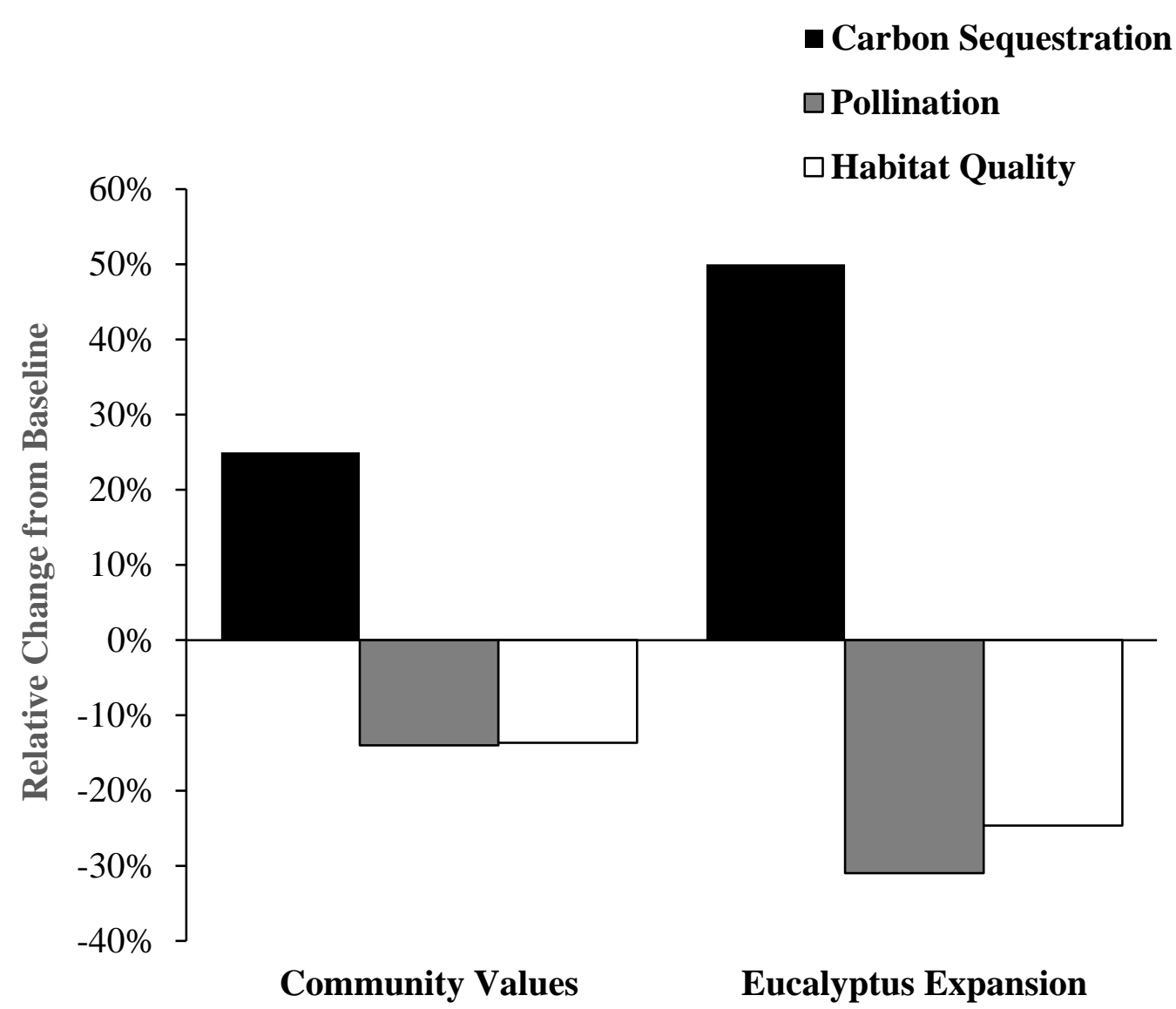

Fig. 7. Comparison of relative chance in ecosystem services compared to baseline landscape. 


\section{Appendix}

\begin{tabular}{|c|c|c|c|c|c|}
\hline \multicolumn{6}{|c|}{$\begin{array}{l}\text { Appendix 1. ¿Qué tan importantes son los siguientes aspectos de la naturaleza que } \\
\text { les rodea tanto para usted como para su hogar? Indique con un círculo sólo una } \\
\text { respuesta. [How important are the following aspects of the nature around them both } \\
\text { for you and for your home? Please circle only one answer.] }\end{array}$} \\
\hline $\begin{array}{l}\text { Que la naturaleza... [That } \\
\text { nature ...] }\end{array}$ & $\begin{array}{l}\text { Nada } \\
{[\text { None }]}\end{array}$ & \begin{tabular}{|l} 
Poco \\
{$[A$} \\
Little $]$
\end{tabular} & $\begin{array}{l}\text { Ni poco ni } \\
\text { mucho } \\
{[\text { Neutral }]}\end{array}$ & $\begin{array}{l}\text { Mucho } \\
{[\text { Some }]}\end{array}$ & $\begin{array}{l}\text { Muchísimo } \\
{[\text { A lot }]}\end{array}$ \\
\hline $\begin{array}{l}\text { Sea un paisaje bonito (p.ej. } \\
\text { vistas agradables) [Be nice } \\
\text { scenery (eg nice views)] }\end{array}$ & 1 & 2 & 3 & 4 & 5 \\
\hline $\begin{array}{l}\text { Dé posibilidades para la } \\
\text { recreación [Give opportunities } \\
\text { for recreation] }\end{array}$ & 1 & 2 & 3 & 4 & 5 \\
\hline Aporte aire limpio [Clean air] & 1 & 2 & 3 & 4 & 5 \\
\hline $\begin{array}{l}\text { Aporte agua limpia [Clean } \\
\text { wáter] }\end{array}$ & 1 & 2 & 3 & 4 & 5 \\
\hline $\begin{array}{l}\text { Provea alimentos cultivados } \\
\text { [Provide food] }\end{array}$ & 1 & 2 & 3 & 4 & 5 \\
\hline $\begin{array}{l}\text { Genere oportunidades } \\
\text { económicas (p.ej. empleos) } \\
\text { [Generate economic } \\
\text { opportunites (eg, jobs) }\end{array}$ & 1 & 2 & 3 & 4 & 5 \\
\hline $\begin{array}{l}\text { Contribuya al hábitat para los } \\
\text { aves [contributes to habitat for } \\
\text { birds] }\end{array}$ & 1 & 2 & 3 & 4 & 5 \\
\hline $\begin{array}{l}\text { Provea gran cantidad de agua } \\
\text { [Provide large quantities of } \\
\text { wáter] }\end{array}$ & 1 & 2 & 3 & 4 & 5 \\
\hline $\begin{array}{l}\text { Mantenga los suelos } \\
\text { productivos [Keep productive } \\
\text { soils] }\end{array}$ & 1 & 2 & 3 & 4 & 5 \\
\hline
\end{tabular}




\begin{tabular}{|l|c|c|c|c|c|}
\hline $\begin{array}{l}\text { Appendix 2. Favor indique con un círculo sólo una respuesta para cada pregunta. } \\
\text { [Please indicate with a circle only one answer for each question.] }\end{array}$ \\
$\begin{array}{l}\text { Pada } \\
\text { Pregunta }\end{array}$ & $\begin{array}{c}\text { Poco } \\
{[\text { A }}\end{array}$ & $\begin{array}{c}\text { Ni poco } \\
\text { ni } \\
\text { mucho }\end{array}$ & $\begin{array}{c}\text { Mucho } \\
\text { [Some] }\end{array}$ & $\begin{array}{c}\text { Muchísimo } \\
\text { [A lot] }\end{array}$ \\
\hline $\begin{array}{l}\text { [Neutral }] \\
\text { Ud. que influyó el gobierno en }\end{array}$ & & & & & \\
$\begin{array}{l}\text { la expansión del eucalipto en } \\
\text { su región? [To what extent do } \\
\text { you consider. Influencing the } \\
\text { government in the expansion } \\
\text { of eucalyptus in your region?] }\end{array}$ & 1 & 2 & 3 & 4 & \\
\hline $\begin{array}{l}\text { ¿Hasta que punto considera } \\
\text { Ud. que debería influir el } \\
\text { gobierno en la promoción de } \\
\text { la expansión del eucalipto? } \\
\text { [To what extent do you } \\
\text { consider. That should } \\
\text { influence the government in } \\
\text { promoting the expansion of } \\
\text { eucalyptus?] }\end{array}$ & 1 & 2 & 3 & 4 & \\
\hline
\end{tabular}




\begin{tabular}{|c|c|c|c|c|c|}
\hline \multicolumn{6}{|c|}{$\begin{array}{l}\text { Appendix 3. Favor de indicar con un círculo su nivel de acuerdo o desacuerdo con } \\
\text { cada afirmación. [Please indicate with a circle your level of agreement or } \\
\text { disagreement with each statement.] }\end{array}$} \\
\hline Afirmación & $\begin{array}{c}\text { Totalmente } \\
\text { en } \\
\text { desacuerdo } \\
\text { [Strongly } \\
\text { Disagree] }\end{array}$ & $\begin{array}{c}\text { Desacuerdo } \\
\text { [Disagree] }\end{array}$ & $\begin{array}{l}\text { Neutral } \\
\text { Neutral } \\
\quad]\end{array}$ & $\begin{array}{l}\text { De } \\
\text { acuerdo } \\
\text { [Agree }]\end{array}$ & $\begin{array}{c}\text { Totalment } \\
\text { e de } \\
\text { acuerdo } \\
\text { [Strongly } \\
\text { agree] }\end{array}$ \\
\hline $\begin{array}{l}\text { El gobierno } \\
\text { hace cumplir } \\
\text { las leyes para } \\
\text { proteger el } \\
\text { medio } \\
\text { ambiente en el } \\
\text { sistema de } \\
\text { producción del } \\
\text { eucalipto. [The } \\
\text { government } \\
\text { enforces laws } \\
\text { to protect the } \\
\text { environment in } \\
\text { the production } \\
\text { system of } \\
\text { eucaliptus] }\end{array}$ & 1 & 2 & 3 & 4 & 5 \\
\hline $\begin{array}{l}\text { El gobierno } \\
\text { responde a las } \\
\text { necesidades de } \\
\text { su comunidad } \\
\text { [The } \\
\text { government } \\
\text { responds to the } \\
\text { needs of their } \\
\text { community] }\end{array}$ & 1 & 2 & 3 & 4 & 5 \\
\hline
\end{tabular}




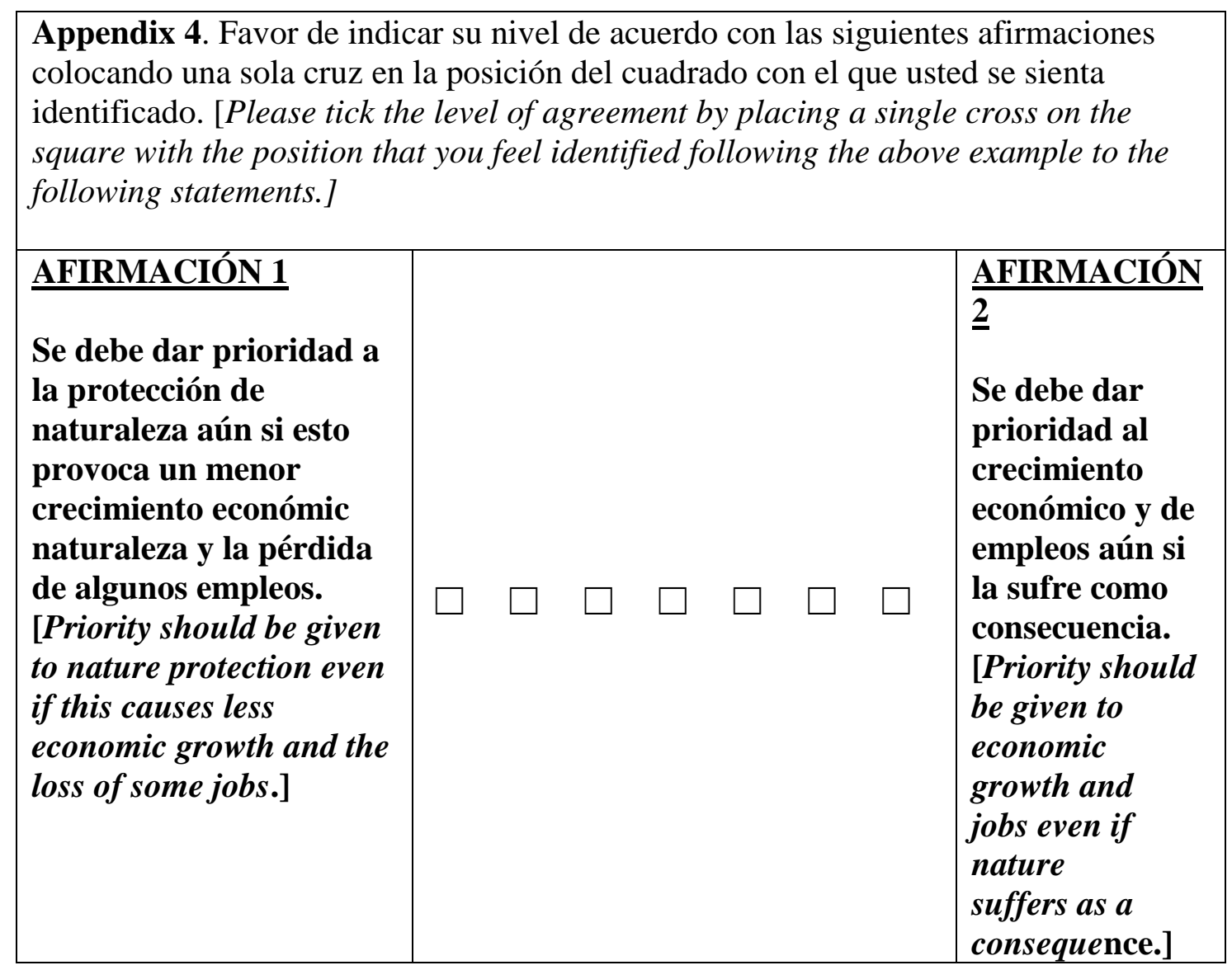


Appendix 5. Bee species and guilds parameters for Pollination Module. Time of activity is based upon field-collected data and relative abundances divided between early and late spring. Nest preference is based upon published sources, with 0 means not suitable. Foraging estimates is estimated from genus bee size. Species are abbreviations using two letters from genus and species; see Chapter 4 for details on bee species.

\begin{tabular}{|c|c|c|c|c|c|c|}
\hline \multirow[b]{2}{*}{ Species } & \multirow[b]{2}{*}{ Cavity } & \multicolumn{2}{|c|}{ Nest preference } & \multicolumn{2}{|c|}{ Time of activity } & \multirow{2}{*}{$\begin{array}{c}\text { Est. } \\
\text { foraging } \\
\text { distance } \\
(\mathrm{m})\end{array}$} \\
\hline & & Soil & $\begin{array}{c}\text { Wood } \\
\text { burring }\end{array}$ & $\begin{array}{c}\text { Early } \\
\text { spring }\end{array}$ & $\begin{array}{c}\text { Late } \\
\text { spring }\end{array}$ & \\
\hline$\overline{\text { CASP }}$ & 0 & 1 & 0 & 0 & 1 & 1000 \\
\hline ANSP & 0 & 1 & 0 & 0.5 & 0.5 & 500 \\
\hline PSSP & 0 & 1 & 0 & 0 & 1 & 500 \\
\hline BOPA & 0 & 1 & 0 & 0.56 & 0.44 & 3000 \\
\hline BOBE & 0 & 1 & 0 & 0.61 & 0.39 & 3000 \\
\hline CETR & 0 & 0 & 1 & 1 & 0 & 250 \\
\hline CESP & 0 & 0 & 1 & 0.73 & 0.27 & 250 \\
\hline ALSP & 0 & 1 & 0 & 0.13 & 0.87 & 250 \\
\hline ANRO & 0 & 1 & 0 & 0 & 1 & 250 \\
\hline MESP & 0 & 1 & 0 & 0 & 1 & 250 \\
\hline PTSP & 0 & 1 & 0 & 0.19 & 0.81 & 250 \\
\hline FLCO & 0 & 1 & 0 & 0 & 1 & 250 \\
\hline GAMI & 0 & 1 & 0 & 0 & 1 & 250 \\
\hline MELSP & 0 & 1 & 0 & 0.05 & 0.95 & 250 \\
\hline SVDE & 0 & 1 & 0 & 0 & 1 & 250 \\
\hline THAN & 0 & 1 & 0 & 0 & 1 & 250 \\
\hline CABR & 0 & 1 & 0 & 0.63 & 0.37 & 500 \\
\hline CHSP & 0 & 1 & 0 & 0.38 & 0.63 & 500 \\
\hline LACL & 0 & 1 & 0 & 1 & 0 & 500 \\
\hline TACH & 0 & 1 & 0 & 0 & 1 & 500 \\
\hline XYSP & 0 & 0 & 1 & 0.66 & 0.34 & 2000 \\
\hline PTLA & 0 & 1 & 0 & 0 & 1 & 250 \\
\hline PELE & 0 & 1 & 0 & 1 & 0 & 250 \\
\hline AUSP & 0 & 0 & 1 & 0.49 & 0.51 & 100 \\
\hline AUGSPA & 0 & 1 & 0 & 0.14 & 0.86 & 100 \\
\hline AUGSPP & 0 & 1 & 0 & 0.68 & 0.32 & 100 \\
\hline PASP & 1 & 1 & 1 & 1 & 0 & 250 \\
\hline THAL & 1 & 1 & 1 & 0.08 & 0.92 & 250 \\
\hline
\end{tabular}




\begin{tabular}{lllllll} 
PSSP & 0 & 1 & 0 & 0.37 & 0.63 & 500 \\
DISP & 0 & 1 & 0 & 0.26 & 0.74 & 100 \\
EPBI & 1 & 0 & 0 & 1 & 0 & 250 \\
LIRU & 0 & 0 & 1 & 0.6 & 0.4 & 250 \\
MESP & 1 & 0 & 0 & 0.54 & 0.46 & 1500 \\
\hline
\end{tabular}




\title{
5. Impacts of stand age on bee and wasp diversity in aspen forests in northeastern Wisconsin, USA
}

\begin{abstract}
Aspen forests are an important part of northeastern Wisconsin's ecological communities and local economy. Forest management can impact native bees and wasps, providers of pollination ecosystem services. To understand how forest management impacts bees in this region, we surveyed bees and wasps with pan traps using a chronosequence of nearly monotypic aspen stands that ranged from 11-45 years old/post-harvest. We also qualified forest habitat features that influence pollinator communities. We found no significant relationship between forest stand age and bee and wasp abundance or richness. However, forest stand age class did impact the abundances of different bee and wasp functional types with pollinating bees more abundant in younger forests and parasitoid wasps more common in older stands. We also detected discrete pollinator communities along the ecological gradients using non-metric multidimensional scaling. Results from our work demonstrate that forest bee and wasp communities respond differently to forested habitats and that forest stand age may be an important driver of habitat features that influence bee and wasp biodiversity. Providing a mosaic of different aged stands on the landscape may help support diverse bee and wasp communities in these Great Lakes forests.
\end{abstract}

\section{Introduction}

Pollinators provide an essential ecosystem service to domestic and wild plants, with nearly $90 \%$ of flowering plants (> 300,000 species globally) depending or benefiting from animal-assisted pollination (Ollerton et al. 2011). Wild bees and other members of the Hymenoptera family, like wasps, are a major provider of this essential service. Approximately $75 \%$ of domesticated crops important to human health and nutrition benefit from insect pollination (Klein et al. 2007), a service estimated to be worth $\$ 215$ billion worldwide (Gallai et al. 2009).

The human demand for pollination-dependent crops has tripled in recent years (Aizen et al. 2008) while at the same time wild bees have declined in Europe and North America (Potts et al. 2010; 2015; Koh et al. 2016). In the United States, wild bee abundance has declined by an estimated 23\% since 2008 (Koh et al. 2016), with uneven patterns across the country. In the Midwest, estimated bee declines are higher than the national average (Koh et al. 2016). A mosaic of agricultural fields and forests dominate land use in this region and compared to more purely agriculture dominated landscapes, far less is known about the value of forested habitats to bees (Sudan 2016). The importance of forests as bee habitat was highlighted by a recent presidential memorandum (The White House $2015 b$ ) to federal agencies that set a goal to reestablish 7 million acres of pollinator habitat on federal lands, much of that on the US Forest Service's lands (The White House 2015a). Consequently, there is a clear need to enhance our understanding how forest management may influence bees and other pollinators. 
In the Midwestern state of Wisconsin, forests make up 6.9 million hectares (Kurtz 2017). Aspen (Populus spp.) forests account for 17\% of the total forestlands (Kurtz 2017) in the state with more than $70 \%$ of these forests stands found the northern part of the state (DNR 2016), making these forests ecologically important to the region. Aspen trees are also an important part of state's timber economy, accounting for $22 \%$ of the statewide harvest for roundwood, with the majority of the wood being used for composite wood or pulp products (DNR 2016). The value of these aspen-dominated forests for bees is understudied; we identified only one paper specifically addressing aspen stands and their value for bee habitat (and this research was conducted in Oregon) (Gonzalez et al. 2013). This study did not examine how silvicultural practices or successional ages may influence this important pollinator group.

Elsewhere in temperate forests, forest successional age has been found to influence bee diversity patterns with species richness and abundance declining with increasing forest age (Winfree et al. 2007; Grundel et al. 2010; Hanula et al. 2016a). However, not all species respond in the same manner. Some bee species are forest obligates (Winfree et al. 2007) and many more species are habitat generalists that visit forests in search of floral resources and nesting materials (Monasterolo et al. 2015). (Winfree et al. 2007). Younger aspen stands are less structurally diverse than older stands but permit more light to reach the forest floor, supporting greater understory floral diversity. Stand age can also impact social and solitary bees differently, with some social colony-nesting bees preferring older successional stands (Taki et al. 2013). Taki (et al. 2013) suggested that older stands often possess more diverse habitat features that can provide nesting resources for some social bees that prefer wood cavities. Related work suggests that bees perceive the landscape based on available floral resources, nesting sites, and over-wintering habitats (Kremen et al. 2007; Williams \& Winfree 2013). The scale of habitat choice among bees differs based upon the home range of the species (Greenleaf et al. 2007; E Benjamin et al. 2014).

In this context, we investigated the possible influence of forest successional age and related fine-scale habitat features on native bees and wasps in northeastern Wisconsin. We surveyed for Hymenoptera species in a chronosequence of aspen-dominated forest stands in the spring and summer of 2014. Based on previous work, we hypothesized that bee and wasp species richness and abundance would be greatest in youngest stands and decline with increasing forest age. This research advances our understanding of ecological theory of forest disturbance and biodiversity patterns on a critically important taxa group, as well as provides important information for forest and land managers on the effects of harvest schedules on wild bees and wasps that provide highly valued pollination services. 


\section{Methods}

\section{Site description}

In 2014, we selected a chronosequence of 9 aspen-dominated, no-retention forest stands in Vilas and Oneida Counties in northeastern Wisconsin (approximately $45^{\circ} 43^{\prime} \mathrm{N}, 89^{\circ}$ $32^{\prime} \mathrm{W}$ ) to represent young, middle-age and older-age aspen stands that ranged from 11-45 years post-harvest (Fig. 1). Selected sites shared mesic soils comprised of sandy loam and loamy sand (Soil Survey Staff 2011). The sites were randomly selected from available forest stands that matched our criteria (larger than 15 ha, contiguous blocks, and no scheduled harvesting) based upon GIS layers supplied by Wisconsin county and state forestry offices. These aspen-dominated sites were originally clear-cut and left to regenerate without additional management, though some sites had a handful of largediameter hardwoods (mostly red oaks, Quercus rubra) and/or conifer (pine trees, Pinus spp.) trees remaining as part of the original silvicultural treatments.

\section{Bee and wasp sampling}

To assess bee and wasp communities, we surveyed the aspen stands described above with pan traps and blue-vane traps, an accepted technique for forested landscapes (Campbell and Hanula 2007; Grundel et al. 2010; Taki et al. 2013; Hanula et al. 2015). These passive techniques allow for sampling at multiple sites at the same time, remove observer bias, and can be repeated at regular intervals. This technique has become the standardized method for North American and European bee monitoring protocols (Westphal et al. 2008; Lebuhn et al. 2012). At each site, we randomly selected origin points to serve as the starting points for our sampling transects, discarding points that were within $50 \mathrm{~m}$ of a road or forest edge so that transects were within the forested habitat. At each point, we laid out two $40 \mathrm{~m}$ transects intersecting at a 60 degree angle, forming a flattened "X" shaped array that allowed for efficient spatially structured sampling (Droege 2015). We marked transects with 1-m high wooden stakes every $5 \mathrm{~m}$. At each stake, a set a $100 \mathrm{~mL}$ plastic cup painted with florescent blue, yellow or white (alternating colors) filled with soapy water (Dawn ${ }^{\mathrm{TM}}$, original scent) for a total of 34 pan traps per site (Droege 2015). At the same time, we hung four florescent blue vane traps (Spring Star Inc.) from low tree branches per site because they are more effective for catching large-bodied bees like bumble bees (Stephen \& Rao 2005; 2007; Kimoto et al. 2012). Traps were set out before 9 am and collected the following day. All insects in the pan traps and blue vane traps were collected and stored in $70 \%$ ethanol until identified. We identified bees to genus or species level using DiscoverLife.org and published dichotomous keys, and wasps to the lowest possible level. Surveys were conducted during mild weather with no rain and repeated approximately every other week during from 28 May through 05 August 2014 for a total of six surveys. 


\section{Habitat sampling}

We collected fine-scale habitat measurements to allow us to evaluate potential relationships between bee and wasp community assemblages and floral and nesting resources that are known to be important for different groups (Williams et al. 2010). We sampled the herbaceous understory plants, woody shrubs, coarse woody debris and forest stands along the same transects used for the bee sampling. Shrub, woody debris and forest stand measurements were sampled once over the course of the summer while floral resources were surveyed six times at the same time of bee and wasp surveys to match floral resources with bee biodiversity patterns.

Each $40 \mathrm{~m}$ transect was divided into four $10 \mathrm{~m}$ segments with sampling stations established at $0,1,3$, and $6 \mathrm{~m}$, employing a cyclical sampling method that minimizes sampling time while maximizing inference (Clinger and Ness 1976; Scheller and Mladenoff 2002; Murray et al. 2013). We counted non-graminoid flowering species using $1 \mathrm{~m}^{2}$ quadrat and visually estimated percent cover of dominant herbaceous plant community within the same quadrat (Grundel et al. 2010). For efficiency, we lumped grasses, sedges and rushes into a generic graminoid category. We also counted the number of rooted woody stems and species within each quadrat. Along the same transects, course woody debris (CWD) was estimated using line intersect method, we recorded debris diameter $(\mathrm{cm})$ at the point of intersection, log species if known, and decay class (1-5) using Jenkin et al. descriptions (Jenkins et al. 2004). Later, we combined decay classes 1-3 into low decay and classes 4 and 5 into high decay categories for data analysis. Lastly, ten $100 \mathrm{~m}^{2}$ circular plots were established and tree species, diameter at breast height (DBH) and status (live/dead) were recorded, with the exception of the three youngest stands where the density of stems was too great and we reduced the circular plot to $50 \mathrm{~m}^{2}$ for expediency. The ends of each $\mathrm{x}$-shaped transects and transect midpoints were used as the circular plot centers. A digital camera with a hemispherical lens was used to photograph the forest canopy along the same plot centers we used for the stand measurements. Images were then analyzed with WinSCANOPY software (WinSCANOPY 2017) to calculate percent canopy that we used as a proxy for light availability, an important driver of understory succession.

\section{Statistical analysis}

Abundance, species richness, and community structure of the bees and wasps were compared using PC-ORD v. 6.22. We then grouped our collection based upon adult ecological function: parasitoid wasps, predatory wasp, kleptoparasitic bee, pollinating bee, forest pest, and unknown. For bees' functional role, we used the United States Geological Survey's functional ecology database of bees (BeeGAP 2016). For non-bees, we searched the literature for nesting and diet needs. We tested for relationship between forest stand age and both abundance and richness with a linear regression. To test for differences between forest ages, we conducted a two-way ANOVA with young, middle and old age stands against parasitic and pollinating bees, predatory and parasitoid wasp and forest pests. Finally, we examined how the bee communities responded to these 
forest stands with a non-metric multidimensional scaling ordination technique, incorporating the forest habitat structure (see above) and bee and wasp species abundance that we pooled to the site level for comparison (McCune and Grace 2002). For this analysis, we used we used a Bray-Curtis measurement of ecological distance and the autopilot defaults (250 iterations). This technique assesses the fit of the community structure by calculating a stress score, with low stress indicative of a stable community and better fit that reflects a true ecological gradient (McCune and Grace 2002).

\section{Results}

In total, we collected 1,670 insects and small spiders from our pan and blue vane traps during the 2014 summer, with June and July being the peak months for abundance (Fig. 3 ). Of the insects sampled, 487 were Hymenoptera (bees and wasps), the group of interest for our study. We described 39 distinct species, though we did not reach species level identification for all groups. Overall, abundances and species richness of bees and wasps were higher in the younger stands and declining in the older aspen forest stands but this relationship was not statistically significant. Forest stand age did affect the composition of insects, with parasitoid wasps more abundant in older forest stands compared to middle or young stands and pollinating bees more common in younger stands (Fig. 4). Fine scale habitat metrics for forest successional age are described in Table 3

Pollinating bees accounted for approximately one-third of all bees collected. Of these, the Halictidae family was the most abundant with the genus Lasioglossum the most common. These 3-4 mm bees are one of the most common bees in Midwestern U.S. forest, and are notoriously difficult to identify to species level. In Wisconsin's northeastern forest, there are at least seventeen species of Lasioglossum bees (Wolf and Ascher 2008). We also collected twelve kleptoparasitic bees and wasps (Nomad sp. and Holopygya ventralis), approximately $2.5 \%$ of the total bees and wasps collected.

Nearly half of our collection was comprised of endoparasitic and ectoparasitic parasitoid wasps, mostly the Ichneumonidae and Braconidae families. These groups are closely related, very diverse at the species level and are difficult to identify below family level. Another $13.9 \%$ of the collection were predatory wasps that prey upon other insects to provision nests but sip nectar as food. Finally, twelve bee or wasp specimens were damaged beyond repair (e.g. missing legs or other body parts) and were excluded from analysis.

We detected discrete bee and wasp communities across the chronosequence of forest sites. The NMDS ordination resolved to a three-dimensional ordination with a final stress level of 9.13 after 50 iterations and zero instabilities (Fig. 5). The three axes of our threedimensional solution collectively described $95.4 \%$ of the variation. Mean diameter at breast height, as a proxy for tree height, basal area and age, along with coarse woody debris were associated with bee and wasp community composition across our sites. 


\section{Discussion}

In northeastern Wisconsin, we documented more than 39 species of bees and wasps in aspen-dominated forest stands that ranged from 11-45 years post-harvest. Forest age was not a significant driver in the abundance or richness patterns in our study, as we originally hypothesized. However, we did detect distinctive bee and wasp communities in each forest successional age category. Consequently, while aggregate bee and wasp abundance and richness at the stand scale may remain relatively stable as forest stands mature, these communities appear to undergo pronounced compositional shifts as they mature following disturbance. Collectively, our results suggest that maintaining a diversity of stand age classes across the landscape will likely enhance overall pollinator diversity.

Most studies that have explored forest successional age structure and bee diversity report a consistent trend that richness and abundance declines with increasing forest age (e.g. Hanula et al. 2015, Hanula et al. 2017, Taki et al. 2013). Our results, however, are more ambiguous and provide only limited evidence to support this trend observed elsewhere. While not statistically significant, younger stands supported more pollinating bees that depend upon floral resources that are more abundant in open canopy forest stands. This is consistent with other studies in temperate and boreal forests that found that younger sites supported greater species abundance and richness (Grundel et al. 2010; Hanula et al. 2015; Rubene et al. 2015a; Roberts et al. 2017). The lack of significance may be the result of our sampling because one site, County D, was disturbed by bears on two occasions, likely lowering our collection totals and impacting our analysis of stand age and abundance and richness. Younger forest stands also have more bare soil that is important for soil burrowing species like Lasioglossum spp. that were very abundant in the younger stands. We detected more parasitoid wasps in the older stands compared to the other ages. The middle-aged stands were approximately 20 years post-harvest and had relatively few bees and wasps, likely because they had neither the structural complexity of older stands nor the rich understory that supports pollinating bees. This forest successional stage (stem exclusion) generally lacks a rich herbaceous understory and therefore likely provides fewer nectar and pollen resources (Fye 1972).

These aspen stands supported a diverse group of native bees and wasps. Wasps such as the eastern yellowjacket (Vespula maculifrons) are often not considered pollinators because of their nearly hairless bodies and predatory role. Wasps provision their nest with "meat" (i.e., caterpillars, carrion and other predated insects) and not pollen. Adult wasps do visit flowers and drink nectar, and have been shown to be pollinators for some plants (Cheng et al. 2009). Their role as potential pollinators for forest plant species in our region remains poorly explored, though in another region where Vespula sp. was nonnative, the wasps preyed upon native bees and were ineffective pollinators for one tree species (Hanna et al. 2012). Nonetheless, they cannot be completely discard wasps as pollinators, and in the absence of bees, this group has been shown to pollinate some forest flowers (Hallett et al. 2017). The parasitic bees and wasps (sometimes called cuckoo bees and wasps) were captured only rarely in our traps (12 total). This 
observation is consistent with other literature that has found pan traps to be ineffective for nest parasitic species because they do not collect pollen, and consequently are less likely to visit flowers (or pan traps that serve as artificial flowers) (Lebuhn et al. 2012). Future research with this group of insects should include both active netting of bees and nest traps; together these supplemental techniques would capture bees and wasps that are under sampled with pan traps alone (Rubene et al. 2015b)

The abundance of parasitoid wasps may also be beneficial to the forest as a whole, and potentially serve as defenders of forest by targeting forest pests. Forty-four percent of these parasitoid wasps were found in the older aspen stands, likely predating on woodchewing insect larva that live beneath tree bark and damage trees. The emerald ash borer (Agrilus planipennis, EAB), for example, is an invasive beetle that is damaging Wisconsin's forests and is considered a major pest to native ash trees (Fraxinus spp), causing high rates of tree mortality with millions of dollars in damages (Kovacs et al. 2010). In other parts of its introduced range in eastern United States, endemic parasitoid wasps have been known to target the EAB as a host species for their eggs (Duan et al. 2013). The Wisconsin Department of Natural Resources is currently releasing an Asian parasitoid wasp that is the natural enemy of EAB as a biocontrol agent for this forest pests (Resources 2016).

One limitation of our work is that we only considered no-retention treatments, a logging technique that is becoming less common in the region during the last two decades. Future work should also consider how alternatives to no-retention silvicultural treatments, like uneven aged or selective logging, could impact bees and wasps in aspen forests. These alternative treatments can positively impact other species groups. For example, conifer and hardwood retention treatments were found to increase avian diversity compared to no-retention logging in the same aspen-dominated landscape compared to no-retention treatments (Roth 2012). Forest clearings and gaps adjacent to mature stands has also been shown to increase bee diversity in temperate and boreal forests (Rubene et al. 2015a; Roberts et al. 2017).

Early successional forests can serve as an important habitat for bees and wasps (Taki et al. 2010; 2013), although older stands were also important for some species (Hanula et al. 2015; Roberts et al. 2017). Our work illustrates a successional pattern in bee community composition following disturbance, with a guild level or functional group shift through time (Roberts et al. 2017). Landscape forest management planning should strive to include both young and old forest stands in a mosaic to provide habitat for these forest associated bees and wasps. Additional research in our region that can illuminate how alternative silvicultural treatments can restore the understory herbaceous layer, open the forest canopy, and maintain timber yields would contribute to a triple "win" for forest bees and wasps, other wildlife and human communities (Hanula et al. 2016b). 


\section{Acknowledgements}

The authors thank the landowners and managers who permitted this research, particularly the Wisconsin Department of Natural Resources and the Forestry Departments of Onieda and Vilas County. We are also very grateful for the hard work of C. Fiser and I. Flaspohler, who assisted in the field. We would also like to thank Michigan Technological University's Ecosystem Science Center and the Sustainable Futures Initiative for its support. The University of Wisconsin Kemp Field Station served as our "home base" for this research and we are thankful to its wonderful staff. This work was funded through the National Science Foundation Partnership in International Research and Education Grant program (award num. 1243444), and the authors would like to thank all the graduate students involved with this project, particularly M. Cisz Brill and J. Lopez who shared in the hard work and trails of this research.

\section{Tables}

Table 1. Bee and wasp Hymenoptera abundances and richness of the collected in nine aspen-dominated forest stands of different ages in northeastern Wisconsin, USA

\begin{tabular}{lllll}
\hline Site name & $\begin{array}{l}\text { Age post- } \\
\text { harvest }\end{array}$ & $\begin{array}{l}\text { Age } \\
\text { Category }\end{array}$ & $\begin{array}{l}\text { Total } \\
\text { Abundance }\end{array}$ & $\begin{array}{l}\text { Total } \\
\text { Richness }\end{array}$ \\
\hline County Y & 11 & Young & 136 & 21 \\
Jerry Rd & 11 & Young & 76 & 23 \\
County D & 15 & Young & 24 & 11 \\
Fawn Lake & 20 & Middle & 65 & 20 \\
Trout Creek Rd & 24 & Middle & 37 & 10 \\
Grouse Rd & 33 & Old & 54 & 14 \\
Woodduck Lake & 34 & Old & 42 & 17 \\
Rainbow Dr & 44 & Old & 22 & 13 \\
New Trout & & Old & & 10 \\
Creek & 45 & & 35 & \\
\hline
\end{tabular}


Table 2. Bee and wasp members of the Hymenoptera collected in aspen-dominated forest stands of different ages and their ecological role in northeastern Wisconsin, USA

Forest stand age

Ecological role and family

Young

Middle

Old

Total

Kleptoparasitic

Apidae

0

Chrysididae

7

1

2

Parasitoid wasps

Aulacidae

6

Braconidae

13

Ichneumonidae

51

Pompilidae

Sphecidae

7

7

Forest pest

Tenthredinidae

10

0

0

10

Pollinator

Andrenidae

Apidae

6

Halictidae

Megachilidae

7

68

9

6

8

20

$4 \quad 25 \quad 52$

29

54

134

0

7

2

15

Predatory wasps

Eumeninae

Pamphiliidae

Sphecidae

Vespinae

Unknown bee

Unknown

Total

$\begin{array}{cccc}1 & 1 & 3 & 5 \\ 13 & 11 & 5 & 29 \\ 0 & 0 & 1 & 1 \\ 17 & 6 & 11 & 34\end{array}$

\begin{tabular}{cccc}
8 & 0 & 4 & 12 \\
\hline 230 & 102 & 155 & 487
\end{tabular}


Table 3. Forest stand habitat measurements northeastern Wisconsin, USA where bee and wasps were trapped in spring and summer 2014.

\begin{tabular}{lcccc}
\hline $\begin{array}{c}\text { Site name and } \\
\text { category }\end{array}$ & $\begin{array}{c}\text { Age post-harvest } \\
\text { (years) }\end{array}$ & $\begin{array}{c}\text { Mean aspen } \\
\text { tree DBH } \\
(\mathrm{cm})\end{array}$ & $\begin{array}{c}\text { Percent } \\
\text { Aspen }(\%)\end{array}$ & $\begin{array}{c}\text { Mean } \\
\text { woody } \\
\text { debris }\left(\mathrm{m}^{3}\right)\end{array}$ \\
\hline $\begin{array}{l}\text { Young } \\
\text { County Y }\end{array}$ & 11 & 3.73 & 98 & 50.8 \\
$\quad$ Jerry Rd. & 11 & 3.71 & 95 & 21.0 \\
$\quad$ County D & 15 & 5.24 & 90 & 10.2 \\
Middle & 20 & 6.85 & 72 & 9.9 \\
Fawn Lake & 24 & 7.39 & 32 & 15.0 \\
$\quad$ Trout Creek Rd. & 33 & 11.41 & 38 & 27.9 \\
Old & 34 & 10.11 & 40 & 27.4 \\
$\quad$ Grouse Rd. & 44 & 22.73 & 48 & 55.1 \\
Woodduck Lake & 45 & 19.26 & 34 & 22.4 \\
Rainbow Dr. & & & & \\
New Trout Creek & & & & \\
\hline
\end{tabular}




\section{Figures}

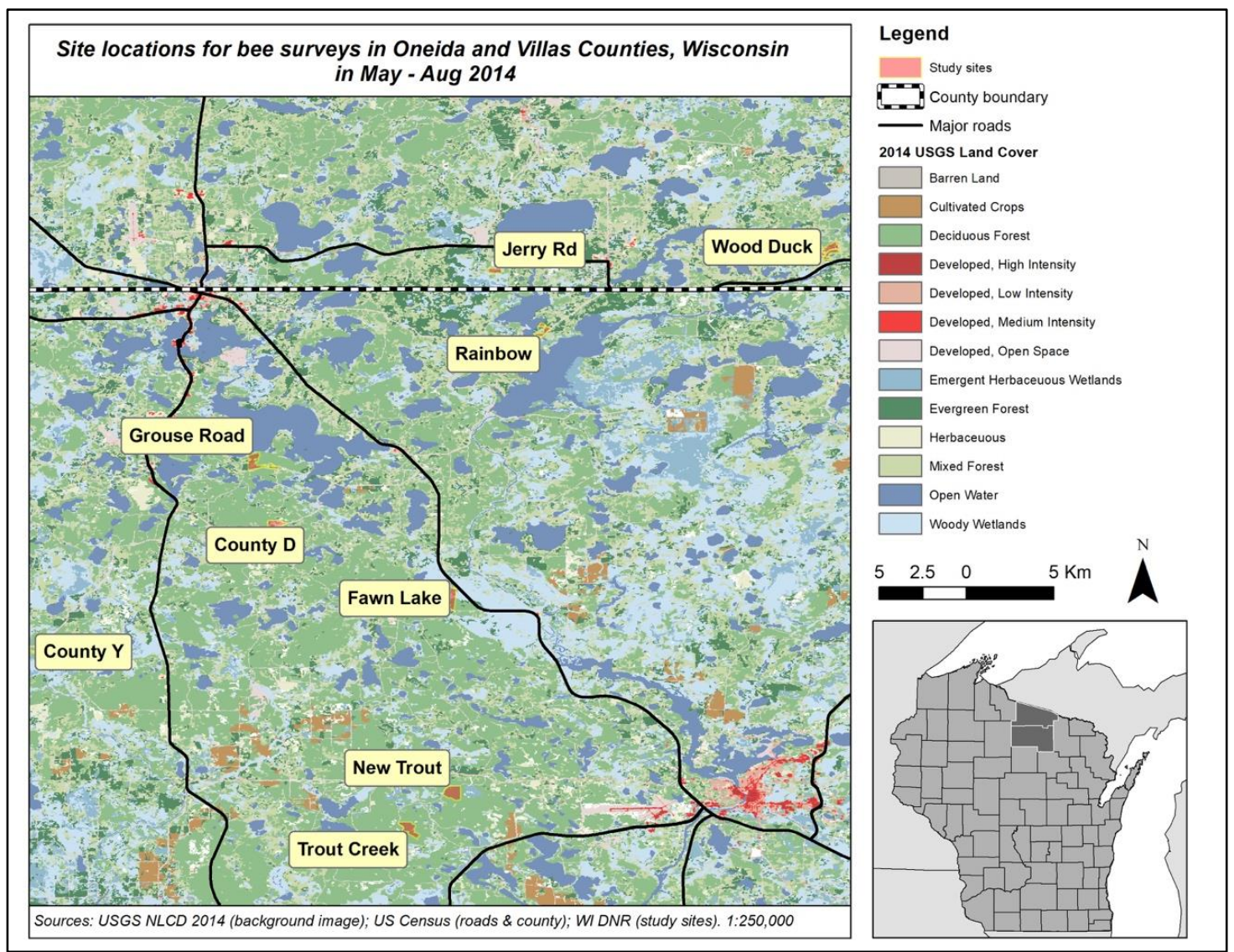

Fig 1. Research sites in Vilas and Oneida Counties in Wisconsin where bees and wasps were collected from aspen-dominated forest stands in May - August 2014. Research sites were randomly selected from available forest stands and broadly are representative of this region's forests and landscape. 

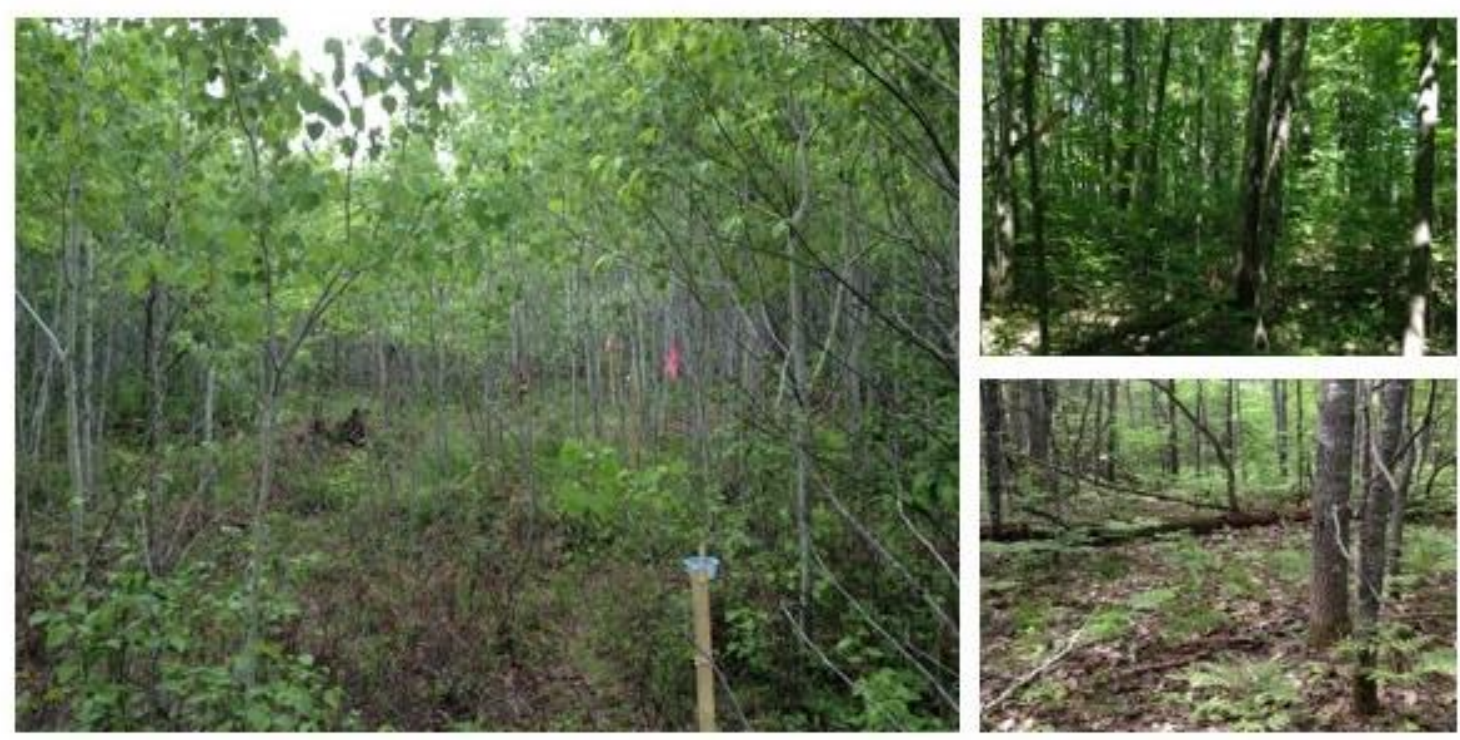

Fig. 2. Examples of young, middle and old (from left, upper right and lower right) aspen forest stands where bees and wasps were sampled in aspen-dominated, no-retention forest stands that ranged from 11-45 years old post-harvest in May - August 2014. Photo credit: C. Phifer

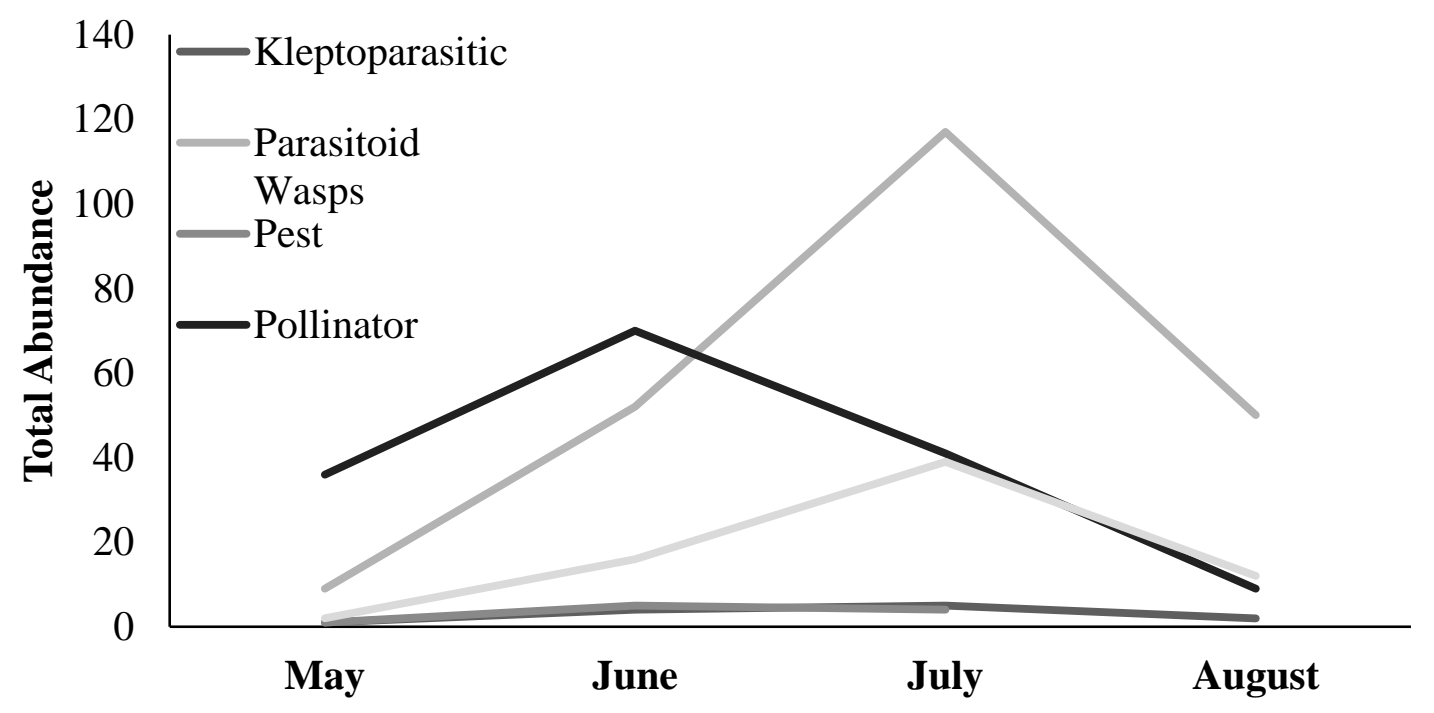

Fig. 3. Temporal patterns of bees and wasps (divided by their ecological role) that were collected from in aspen-dominated, no-retention forest stands that ranged from 11-45 years old post-harvest in May - August 2014 in Vilas and Oneida Counties, Wisconsin. 


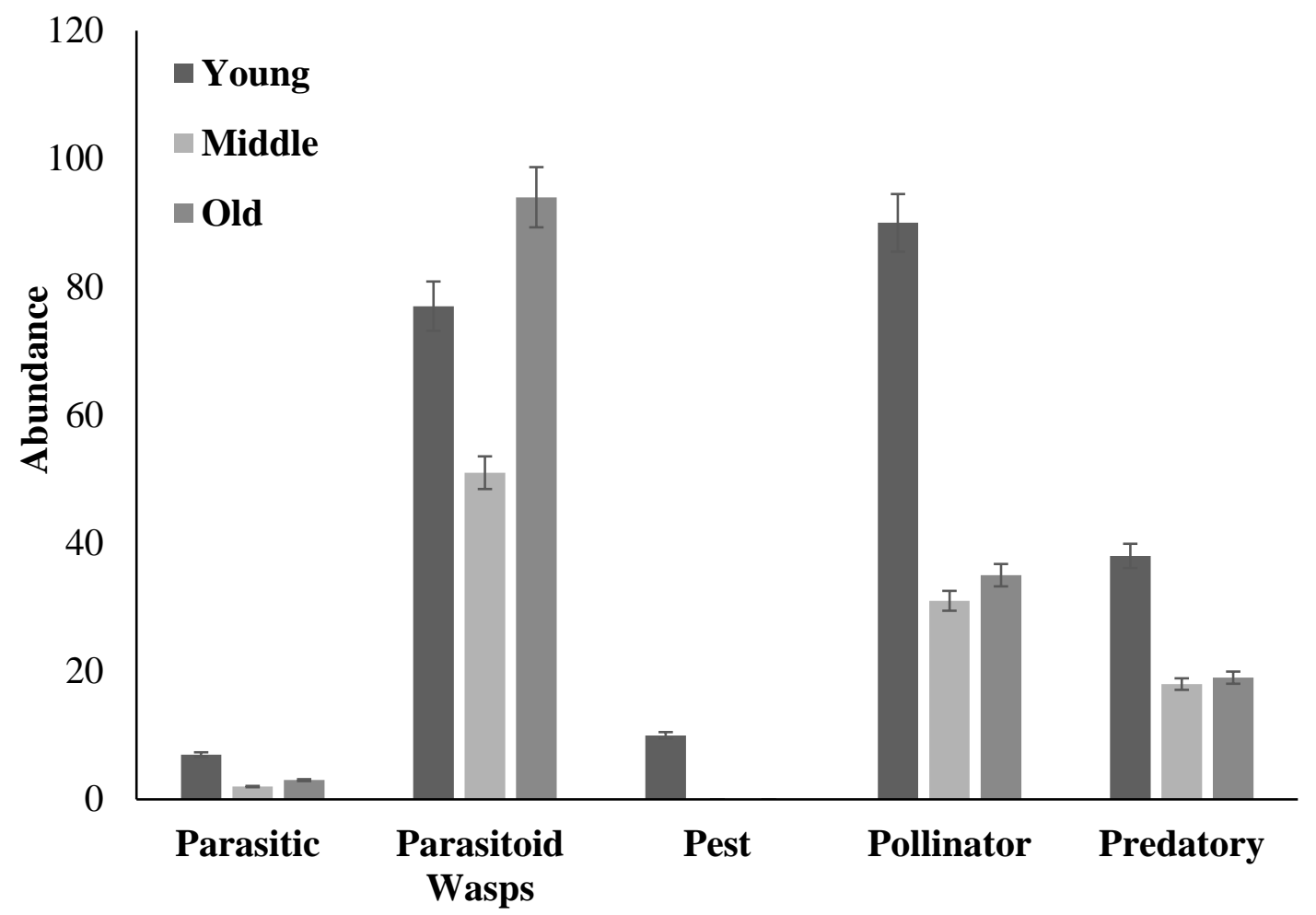

Fig. 4. Abundance patterns of bees and wasps (divided by their ecological function) that were collected from in aspen-dominated, no-retention forest stands that ranged from 1145 years old post-harvest in May - August 2014 in Vilas and Oneida Counties, Wisconsin. Standard error bars are shown. 


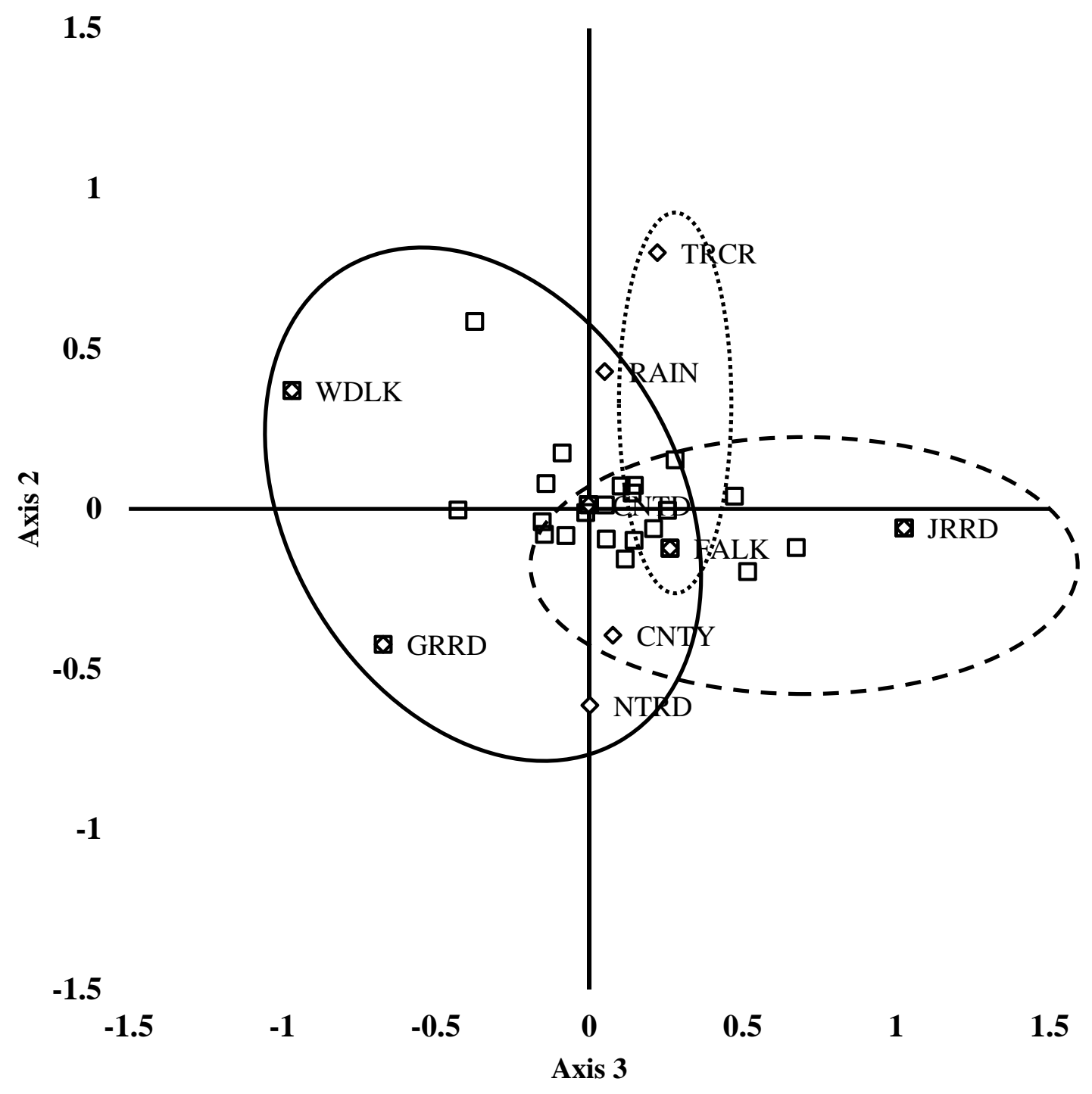

Fig. 5. NMDS of bees and wasps collected from pan traps in a chronosequence of aspendominated forest stands in northeastern Wisconsin. Final solution was a threedimensional ordination; here Axis 2 and 3 are displayed for simplicity. Black open squares are bees or wasp species and open diamonds are the sites sampled. Solid black line is the older aspen stands, dotted black line is the middle age stands and the dashed black line is the younger sites. 


\section{Literature cited}

Aizen, M. A., L. A. Garibaldi, S. A. Cunningham, and A. M. Klein. 2008. Long-Term Global Trends in Crop Yield and Production Reveal No Current Pollination Shortage but Increasing Pollinator Dependency. Current Biology. 18(20):1572-1575.

BeeGAP. 2017. United States Geological Survey, Biological Resource Division, Chesterton, IN.

Campbell, J. W., and J. L. Hanula. 2007. Efficiency of Malaise traps and colored pan traps for collecting flower visiting insects from three forested ecosystems. J Insect Conserv. 11(4):399-408.

Cheng, J., J. Shi, F. Z. Shangguan, A. Dafni, Z. H. Deng, and Y. B. Luo. 2009. The pollination of a self-incompatible, food-mimic orchid, Coelogyne fimbriata (Orchidaceae), by female Vespula wasps. Annals of Botany. 104(3):565-571.

Clinger, W., and J. W. V. Ness. 1976. On Unequally Spaced Time Points in Time Series. The Annals of Statistics. 4(4):736-745.

Department of Natural Resources, Wisconsin. 2016. Aspen report 2016. Available online at: http://dnr.wi.gov/topic/ForestBusinesses/documents/AspenReport.pdf.

Droege, S. 2015. The very handy manual: How to catch and identify bees and manage a collection. Available online at:

http://www.pwrc.usgs.gov/nativebees/Handy\%20Bee\%20Manual/Handy\%20Bee\%2 0Manual.pdf.

Duan, J. J., P. B. Taylor, R. W. Fuester, R. R. Kula, and P. M. Marsh. 2013. Hymenopteran Parasitoids Attacking the Invasive Emerald Ash Borer (Coleoptera: Buprestidae) in Western and Central Pennsylvania. http://dx.doi.org/10.1653/024.096.0122.96(1):166-172.

E Benjamin, F., J. R Reilly, and R. Winfree. 2014. Pollinator body size mediates the scale at which land use drives crop pollination services Osborne, J. (ed.). J Appl Ecol. 51(2):440-449.

Fye, R. 1972. The effect of forest disturbances on populations of wasps and bees in northwestern Ontario (Hymenoptera: Aculeata). The Canadian Entomologist. :16231633.

Gallai, N., J.-M. Salles, J. Settele, and B. E. Vaissière. 2009. Economic valuation of the vulnerability of world agriculture confronted with pollinator decline. Ecological Economics. 68(3):810-821.

Gonzalez, N., S. J. DeBano, C. Kimoto, R. V. Taylor, C. Tubbesing, and C. Strohm. 2013. Native Bees Associated with Isolated Aspen Stands in Pacific Northwest Bunchgrass Prairie. Natural Areas Journal. 33(4):374-383.

Greenleaf, S. S., N. M. Williams, R. Winfree, and C. Kremen. 2007. Bee foraging ranges and their relationship to body size. Oecologia. 153(3):589-596.

Grundel, R., R. P. Jean, K. J. Frohnapple, G. A. Glowacki, P. E. Scott, and N. B. Pavlovic. 2010. Floral and nesting resources, habitat structure, and fire influence bee distribution across an open-forest gradient. Ecological Applications. 20(6):16781692.

Hallett, A. C., R. J. Mitchell, E. R. Chamberlain, and J. D. Karron. 2017. Pollination 
success following loss of a frequent pollinator: the role of compensatory visitation by other effective pollinators. AoB PLANTS. 9(3):1-11.

Hanna, C., D. Foote, and C. Kremen. 2012. Invasive species management restores a plant-pollinator mutualism in Hawaii Steffan-Dewenter, I. (ed.). J Appl Ecol. 50(1):147-155.

Hanula, J. L., M. D. Ulyshen, and S. Horn. 2016a. Conserving Pollinators in North American Forests: A Review. Natural Areas Journal. 36(4):427-439.

Hanula, J. L., S. Horn, and J. J. O'Brien. 2015. Have changing forests conditions contributed to pollinator decline in the southeastern United States? Forest Ecology and Management. 348(C):142-152.

House, The White. 2015a. Pollinator health task force: National strategy to promote the health of honey bees and other pollinators. Washington, DC. Available online at: https://obamawhitehouse.archives.gov/sites/default/files/microsites/ostp/Pollinator\%2 0Health\%20Strategy\%202015.pdf.

House, The White. 2015b. Presidential memorandum - Creating a federal strategy to promote the health of honey bees and other pollinator. :1-5.

Klein, A.-M., B. E. Vaissière, J. H. Cane, I. Steffan-Dewenter, S. A. Cunningham, C. Kremen, and T. Tscharntke. 2007. Importance of pollinators in changing landscapes for world crops. Proceedings of the Royal Society B: Biological Sciences. 274(1608):303-313.

Koh, I., E. V. Lonsdorf, N. M. Williams, C. Brittain, R. Isaacs, J. Gibbs, and T. H. Ricketts. 2016. Modeling the status, trends, and impacts of wild bee abundance in the United States. Proc Natl Acad Sci USA. 113(1):140-145.

Kovacs, K. F., R. G. Haight, D. G. McCullough, R. J. Mercader, N. W. Siegert, and A. M. Liebhold. 2010. Cost of potential emerald ash borer damage in U.S. communities, 2009-2019. Ecological Economics. 69(3):569-578.

Kurtz, C. M. 2017. Forests of Wisconsin, 2016. :1-4 Available online at: https://doi.org/10.2737/FS-RU-108.

Lebuhn, G., S. Droege, E. F. Connor, B. Gemmill-Herren, S. G. Potts, R. L. Minckley, T. Griswold, et al. 2012. Detecting Insect Pollinator Declines on Regional and Global Scales. Conservation Biology. 27(1):113-120.

McCune, B., and J. B. Grace. 2002. Analysis of ecological communities. MJM Publishing Software Design, Gleneden Beach, OR, USA.

Monasterolo, M., M. M. L, V. G. R, and S. A. 2015. Soybean crops may benefit from forest pollinators. "Agriculture, Ecosystems and Environment." 202:217-222.

Murray, B. D., C. R. Webster, and J. K. Bump. 2013. Broadening the ecological context of ungulate-ecosystem interactions: the importance of space, seasonality, and nitrogen. Ecology. 94(6):1317-1326.

Ollerton, J., R. Winfree, and S. Tarrant. 2011. How many flowering plants are pollinated by animals? Oikos. 120(3):321-326.

Potts, S. G., J. C. Biesmeijer, C. Kremen, P. Neumann, O. Schweiger, and W. E. Kunin. 2010. Global pollinator declines: trends, impacts and drivers. Trends in Ecology \& Evolution. 25(6):345-353.

Potts, S. G., S. P. M. Roberts, R. Dean, G. Marris, M. A. Brown, R. Jones, P. Neumann, and J. Settele. 2015. Declines of managed honey bees and beekeepers in Europe. 
Journal of Apicultural Research. 49(1):15-22.

Resources, Wisconsin Department of Natural. 2016. Wisconsin Department of Natural Resources Forest Health 2016 Annual Report. :1-25 Available online at: http://dnr.wi.gov/topic/ForestHealth/documents/AnnualReport2016.pdf.

Roberts, H. P., D. I. King, and J. Milam. 2017. Factors affecting bee communities in forest openings and adjacent mature forest. Forest Ecology and Management. 394:111-122.

Rubene, D., M. Schroeder, and T. Ranius. 2015a. Diversity patterns of wild bees and wasps in managed boreal forests: Effects of spatial structure, local habitat and surrounding landscape. Biological Conservation. 184(C):201-208.

Rubene, D., M. Schroeder, and T. Ranius. 2015b. Estimating bee and wasp (Hymenoptera: Aculeata) diversity on clear-cuts in forest landscapes - an evaluation of sampling methods Didham, R. (ed.). Insect Conservation and Diversity. 8(3):261271.

Scheller, R. M., and D. J. Mladenoff. 2002. Understory Species Patterns and Diversity in Old-Growth and Managed Northern Hardwood Forests. Ecological Applications. 12(5):1329-1343.

Soil Survey Staff. 2011. Natural Resources Conservation Service, United States Department of Agriculture. Web Soil Survey.

Sudan, R. 2016. The effects of forest age and management on bee communities of production forests in the southern United States. :1-64.

Taki, H., I. Okochi, K. Okabe, T. Inoue, H. Goto, T. Matsumura, and S. Makino. 2013. Succession Influences Wild Bees in a Temperate Forest Landscape: The Value of Early Successional Stages in Naturally Regenerated and Planted Forests Ollerton, J. (ed.). PLoS ONE. 8(2):e56678-8.

Taki, H., T. Inoue, H. Tanaka, H. Makihara, M. Sueyoshi, M. Isono, and K. Okabe. 2010. Responses of community structure, diversity, and abundance of understory plants and insect assemblages to thinning in plantations. Forest Ecology and Management. 259(3):607-613.

Westphal, C., R. Bommarco, G. Carré, E. Lamborn, N. Morison, T. Petanidou, S. G. Potts, et al. 2008. Measuring bee diversity in different European habitats and biogeographical regions. Ecological Monographs. 78(4):653-671.

Williams, N. M., E. E. Crone, T. H. Roulston, R. L. Minckley, L. Packer, and S. G. Potts. 2010. Ecological and life-history traits predict bee species responses to environmental disturbances. Biological Conservation. 143(10):2280-2291.

WinSCANOPY. 2017. Regent Instruments and Software. URL: http://www.regentinstruments.com/index.html

Winfree, R., T. Griswold, and C. Kremen. 2007. Effect of Human Disturbance on Bee Communities in a Forested Ecosystem. Conservation Biology. 21(1):213-223.

Wolf AT, Ascher JS. 2009. Bees of Wisconsin (Hymenoptera: Apoidea: Anthophila). Great Lakes Entomologist. 


\section{Conclusion and final reflections}

\section{The social and ecological sustainability of bioenergy}

In this project, I explored how bioenergy associated land-use change and land management practices influenced bird and bee communities and their associated ecosystem services. As part of the broader MTU bioenergy project, I considered these changes through the lens of a bioenergy future, contrasting the potential bioenergy feedstocks with alternative land uses in Argentina and the United States. These chapters are one part of what has been a long journey that led me through four countries in the Americas over the last four years. I document my research scholarship from Brazil and Mexico in Appendix A, which includes the citations of peer-reviewed articles that I contributed to from those countries.

In Argentina, the transition from pasture and annual crops to eucalyptus plantations, the potential bioenergy feedstock, resulted in declines in species richness, abundances and overall simpler communities of bees and birds. The effect size was substantial: only $1 \%$ of bees and $5 \%$ of birds of the total were observed in the eucalyptus plantations. In this region, the sharp structural change from the common pasture/annual crops to dense plantations with tall trees and closed canopies changes the local and micro habitats that grassland-associated species depend upon. However, the effects did not extend far beyond the plantations and bird and bee abundances rebounded once outside the plantation's borders. In addition to changes to biodiversity patterns, I also examined how eucalyptus plantation expansion impacted carbon sequestration and pollination services of wild bees using ecosystem service modeling software. This work integrated the social science findings from the Argentine community interviews and surveys to create a plausible land-use map of region that limited plantation expansion and increased orchards, an interpretation of the communities' preferences. I also created a plausible map that featured a $200 \%$ expansion of the eucalyptus plantations, a likely outcome considering the policies and favorable market conditions. I then contrasted changes in ecosystem services between these two future scenarios and the current land uses. The results demonstrated that plantations have the potential to negatively impact biodiversity and pollination service but can be a source of carbon sequestration.

Taken together, these results demonstrate how land-use change can impact species and ecosystems, and to my knowledge, they are the first of their kind in this region.

Consequently, these results should be carefully considered and future research is needed. Priorities for new research include: 1) work to directly consider both the size and spatial arrangements of eucalyptus plantations; 2 ) reduce tree densities as a possible means to minimize the impacts on biodiversity and ecosystem services; 3 ) evaluate the value of the eucalyptus flowers as a food source to native bees and potentially insectivores birds (that may prey upon them) ; and 4) validate estimates of changes in ecosystem services with ground-truthed values. 
Unlike the Argentine case study, which focused on novel feedstocks and dramatic landuse changes, the United States case study considered the effects of land and forest management on wild bees in naturally occurring aspen forests in northeastern Wisconsin. This story is considerably more nuanced than just land-use change alone, and consequently I surveyed for bees in a chronosequence of differently aged aspen stands and collected detailed habitat characteristics. Broadly, bee abundance, richness and community structure shifted with forest stand age. Bee abundance declined with increasing stands age though this relationship was not statistically significant. My works suggests that although more bee species use younger forest habitats, some bee species were only found in older, more mature stands, particularly bumble bees. These results suggest that no-retention treatments (i.e., clear cuts) can provide habitat to wild bees but that a mosaic of different aged forest stands are needed to provide habitats for the diverse bee communities in its entirety. Future research should consider the potential impacts of alternative silvicultural treatments, like hard-wood retention or uneven-aged management, on bee communities.

This work represents one part of the broader assessment of the social and ecological sustainability of bioenergy. My work reflects my interest in biodiversity conservation in in human-modified landscapes, regardless of what the policy driver is. Alone, however, it is only part of the answer to the sustainability bioenergy development. Future work should further integrate the social and natural science findings and weigh the trade-offs of land-use change and its impacts long-term viability of bioenergy.

\section{Interdisciplinary research - personal reflection}

Almost 20 years ago, Dr. Jane Lubchenco called for a new type of science, indeed a new social contract between society and science that focused on the interconnected and global environmental challenges facing society (Lubchenco 1998). In short, she suggested that scientists must begin to collaborate and work in teams to answer boundary-crossing environmental and sustainability research questions. This call to action, a "Century of the Environment," published in Science, inspired me in my career choice, including choosing to participate in this research project and purse a doctoral degree. I would not have chosen this project, university or career path were it simply a biodiversity assessment. Rather, I was attracted to the prospects of working within an interdisciplinary team to address sustainability-related questions of local and global importance.

To realize the Century of Environment, science must become more collaborative. Indeed, science teams are increasing the engines of discovery, and one must be prepared to work collaboratively in a group to be successful in science (Wuchty et al. 2007; Read et al. 2016). A recent survey of scientists identified 40 top questions relating to sustainability, and to answer nearly all of them will require insights, techniques and expertise from more than one scientific discipline (Kramer et al. 2017). However, interdisciplinary research can come at the expense of slower publication rates (Leahey et al. 2017) and lower rates of funding (Bromham et al. 2016), two important metrics for academic positions. An interdisciplinary career runs against the standard siloed academic pathway, which is 
organized around departments and single disciplines. An interdisciplinary career is, in part, a choice and an expression of one's values and priorities.

Successful interdisciplinary work is built upon a deep foundation in individual disciplines; from my experience, one must understand and know the methods, ideas and theories of one discipline to then effectively build bridges between two or more sciences, and connect different ways of knowing and describing the world. As a member of an international, interdisciplinary research group, I have learned and tried to practice the values necessary for successful team science. Below I present three key points to consider and practice for successful interdisciplinary team science:

One, develop a clear framework for integration early on and return to it often. Finding a means to integrate and utilize the expertise of team members remains one of the biggest challenges to interdisciplinary research (Bromham et al. 2016). Part of the slowness in publishing comes from the extra time needed a priori to create a shared conceptual model that can link together many different types of data (Bromham et al. 2016). It is important to make the interdisciplinary methods "operational" - that is, to connect the research methods and data with the shared conceptual model. And, as a group, return to the model frequently for inspiration and refinement in an iterative fashion.

Two, practice open communication in your team, and assume the best intentions. As a first step, think carefully who you invite to be a member of the group: scientific expertise is not alone a sufficient for team science. To be successful as group, one must actively be present, engaged and empathetic - with oneself, with each other. Research is hard; sharing and coordinating research is even harder. As a team, it is important to establish and practice communication norms and set (and stick with) regular meetings, whether inperson or remote. Researchers that frequently work together build strong social norms and capital that makes the hard work of research integration easier (Leahey et al. 2017).

Third, build your team with deep, yet broad expertise. One must first know their "home" discipline before learning to respect, appreciate and integrate with another one.

Successful interdisciplinary teams should have both discipline-specific experts and a few well-rounded generalists who can move laterally between the group, finding the points of commonality and engineering strategies for integration. Consider adopting 80/20 or 75/25 ratio of expertise in one's own discipline and knowledge and respect for another. Finally, team members should coordinate the timeline of integration, recognizing that different research methods require different inputs of time and resources. Following data collection, data must be curated and analyzed, and only when "ripe" can it be shared and applied to an integrated model.

Others in the MTU team have published best practices and reflections on interdisciplinary research and teaching (Knowlton et al. 2014; Halvorsen et al. 2016; Norris et al. 2016). I do not mean to suggest these three principles are the only ones needed for interdisciplinary research. But these are the three that I meditated on and ones that continued to resurface again and again in my research. This project was designed to cross 
borders in disciplines and countries. I have tried to cross these boundaries and make it easier for others to do the same.

Interdisciplinary work, in short, is not easy or fast. For me, however, it remains a central part of my career goals and research agenda: to advance human and natural well-being through the co-production of scientific knowledge that leads to action. There exists an urgent need to recognize the many unknowns in conservation science and develop an active research agenda to answer those questions. But we must also be ready to share what we know and be ready to act upon it, and do so in a way that communicates more than p-values; for science alone does not change opinions or policy (Lubchenco 2017; Keeler et al. 2017).

I began this project as an ecologist with interests in biodiversity conservation and ecological interactions. I have grown from a quadrat-based, biodiversity-only ecologist to an effective, discipline-crossing conservation biologist and a member of a team studying social and ecological systems and sustainability. I believe this latter development will be where and how I contribute to science and conservation, and do my best to answer the Dr. Lubchenco's challenge to answer the call of the Century of the Environment.

\section{Literature cited}

Bromham L, Dinnage R, Hua X. 2016. Interdisciplinary research has consistently lower funding success. Nature 534:684-687. Nature Publishing Group, a division of Macmillan Publishers Limited. All Rights Reserved.

Halvorsen KE et al. 2016. A case study of strategies for fostering international, interdisciplinary research. Journal of Environmental Studies and Sciences 6:313-323. Springer US.

Keeler BL et al. 2017. Society is ready for a new kind of science-is academia? BioScience 67:591-592. Oxford University Press.

Knowlton J, Halvorsen K, Handler R, O'Rourke M. 2014. Teaching interdisciplinary sustainability science teamwork skills to graduate students using in-person and webbased interactions. Sustainability 6:9428-9440. Multidisciplinary Digital Publishing Institute.

Kramer DB, Hartter J, Boag AE, Jain M, Stevens K, Nicholas KA, McConnell WJ, Liu J. 2017. Top 40 questions in coupled human and natural systems (CHANS) research. Ecology and Society 22: 44-120.

Leahey E, Beckman CM, Stanko TL. 2017. Prominent but less productive. Administrative Science Quarterly 62:105-139.

Lubchenco J. 1998. Entering the century of the environment: a new social contract for 
science. Science 279: 491-497.

Lubchenco J. 2017. Environmental science in a post-truth world. Frontiers in Ecology and the Environment 15:3-3.

Norris PE, O'Rourke M, Mayer AS, Halvorsen KE. 2016. Managing the wicked problem of transdisciplinary team formation in socio-ecological systems. Landscape and Urban Planning 154:115-122. Elsevier B.V.

Read EK, O'Rourke M, Hong GS, Hanson PC, Winslow LA, Crowley S, Brewer CA, Weathers KC. 2016. Building the team for team science. Ecosphere 7:e01291-9.

Wuchty S, Jones BF, Uzzi B. 2007. The increasing dominance of teams in production of knowledge. Science 316:1036-1039. 


\section{Appendix A: related publications}

Below are related peer-reviewed publications that I contributed to as part of PIRE research team. I am including these citations to demonstrate and record my scholarship activities during my PhD. I have included the titles, abstracts, authors and complete citations. Publications are organized in the order in which they were published, with the title serving as the header. Citations are formatted according to the published journal's specifications.

\section{A case study of strategies for fostering international, interdisciplinary research}

Abstract: Bringing together and successfully managing a highly interdisciplinary (ID) research team of socioeconomic, biophysical, and engineering scientists is highly challenging, particularly when that team includes 20 scientists and students across six countries. This paper reports on the results of evaluating the success of such a team as it studies the socioecological impacts of bioenergy development across the Americas. We find that the team has succeeded according to several different metrics. We demonstrate that the literature on accelerated sustainability transitions and small group team creation, development, and management holds valuable les- sons for the success of ID teams.

Citation: Halvorsen, K., Knowlton, J., Mayer, A., Phifer, C., Martins, T., Pischke, E., Propato, T., Cavigliasso, P., Garcia, C., Chiappe, M. and Eastmond, A. 2016. A case study of strategies for fostering international, interdisciplinary research. Journal of Environmental Studies and Sciences 6(2): 313-323

\section{Forest reserves and riparian corridors help maintain orchid bee (Hymenoptera: Euglossini) communities in oil palm plantations in Brazil}

Abstract: Orchid bees (Apidae, Euglossini) are important pollinators in the Amazon forest. In eastern Brazilian Amazon, secondary forest and pastures are being replaced by oil palm plantations. Here, we tested the role of forest reserves and riparian corridors in maintaining orchid bees. We sampled bees in three different soil-type uses, comparing richness, abundance, and assemblage composition. Estimated richness was lowest in palm plantations than in forest reserves and riparian corridors on diversity of orchid bees. Riparian corridors had the highest abundance, followed by reserves, and oil palm plantations. Bee assemblage also varied with land cover, with the reserves having the most distinct composition. We also identified indicator bees for primary forest. Our results demonstrate riparian corridors and forest reserves can maintain orchid bees in oil palm landscapes.

Citation: Brito, T, Phifer, C., Knowlton, J., Fiser, C., Becker, N. Barro, F., et al. 2017. Forest reserves and riparian corridors help maintain orchid bee communities in oil palm plantations. Apidologie 48:575-587 


\title{
Oil palm plantations affect movement behavior of a key member of mixed-species flocks of forest birds in Amazonia, Brazil
}

\begin{abstract}
Oil palm (Elaeis guineensis) is a rapidly expanding crop in the Amazonian region of Brazil. Brazilian law requires all landowners, including oil palm plantations, to maintain forest reserves and forested riparian corridors as a way to limit biodiversity losses. Because of these laws and the forest-like structure of oil palm, these plantations may function as habitat for some native species in the region. We tested this assumption by experimentally translocating Cinereous Antshrikes (Thamnomanes caesius), a forest understory insectivorous bird and nuclear member of mixed-species flocks, from forest reserves to riparian corridors within a large oil palm plantation landscape and tracked their movements back to their home ranges. In total, we recorded the movements of 18 individuals, 8 of which were translocated. The other 10 individuals were tracked within their home ranges in the forest reserves. Six of the eight translocated birds successfully returned to their forest home range, but only one bird flew through the more direct route back through the oil palm matrix while the rest took longer routes through adjoining riparian corridors. Homing time for translocated birds averaged 9.57 (2.23 SE) days. The home range of birds within the forest reserves averaged 2.39 (0.69 SE) ha, and, with the exception of the single returning bird, Cinereous Antshrikes were never detected in oil palm. Our results suggest that oil palm plantations are a barrier to movements of our study species, and that riparian corridors connecting forest fragments may be effective routes for dispersal.
\end{abstract}

Citation: Knowlton, J., Phifer, C. et al. 2017. Oil palm plantations affect movement behavior of a key member of mixed-species flocks of forest birds in Amazonia, Brazil. Tropical Conservation Science. DOI:10.1177/1940082917692800

\section{Diversity and abundance of bees (Hymenoptera: Apoidea) in oil palm agroecosystems and cultivated pastures in Tabasco, Mexico}

Abstract: The objective of the study was to determine the diversity and abundance of wild bees in agroecosystems of oil palm and grasslands in an agricultural area of the state of Tabasco, Mexico. Weekly samplings from June to November 2015 were carried out on four adult oil palm plantations and four pasture areas located in the municipalities of Jalapa and Tacotalpa in the south of this state. The bees were caught using traps made of plastic containers of various colors containing water with detergent. In each site 10 traps placed on a wooden stake $1 \mathrm{~m}$ above the ground were used. In total, 790 specimens of bees belonging to two families (Halictidae and Apidae), 22 genera and 102 species morphologically distinct were captured. 20 genera, 91 species and 662 specimens were recorded in pasture, and 15 genera, 40 species and 128 specimens were recorded in oil palm. The most abundant species in pasture were Apis mellifera, Euglossa sp. and Melitoma sp., and in oil palm were Euglossa sp., Augochlora nigrocyanea, and A. mellifera. The Shannon index indicated high diversity in species richness for both agroecosystems, but the diversity was 1.3 times greater in pasture than in oil palm. The Sorensen coefficient of similarity revealed a low similarity between both agroecosystems, 
with 23 shared species. A species accumulation curve was elaborated and through the Clench equation, 143 species for the pasture and 74 species for the oil palm agroecosystem were estimated. The greatest richness in the pasture with respect to oil palm was possibly related to the vegetation cover, the attraction method used and the diversity of flowering plants that grow in both agroecosystems. It is concluded that the two agroecosystems are important in maintaining the current diversity of wild bees, thus contributing to the ecosystem services of pollination in the studied area.

Citation: Jiménez, M., Soto, López, J., Nápoles, J. Knowlton, C. Phifer, D. Flaspohler, A. Méndez. 2017. Diversity and abundance of bees (Hymenoptera: Apoidea) in oil palm agroecosystems and cultivated pastures in Tabasco, Mexico. Nicaraguan Journal of Entomology: 115

\section{Barriers and solutions to conducting large international, interdisciplinary research projects}

Abstract: Global environmental problems such as climate change are not bounded by national borders or scientific disciplines, and therefore require international, interdisciplinary teamwork to develop understandings of their causes and solutions. Interdisciplinary scientific work is difficult enough, but these challenges are often magnified when teams also work across national boundaries. The literature on the challenges of interdisciplinary research is extensive. However, research on international, interdisciplinary teams is nearly non-existent. Our objective is to fill this gap by reporting on results from a study of a large interdisciplinary, international National Science Foundation Partnerships for International Research and Education (NSF-PIRE) research project across the Americas. We administered a structured questionnaire to team members about challenges they faced while working together across disciplines and outside of their home countries in Argentina, Brazil, and Mexico. Analysis of the responses indicated five major types of barriers to conducting interdisciplinary, international research: integration, language, fieldwork logistics, personnel and relationships, and time commitment. We discuss the causes and recommended solutions to the most common barriers. Our findings can help other interdisciplinary, international research teams anticipate challenges, and develop effective solutions to minimize the negative impacts of these barriers to their research.

Citation: Pischke, E., Knowlton, J., Phifer, C., Lopez, J., Propato, T., Eastmond, A., Martins de Souza, T., Kuhlberg. M., Picasso Risso, V., Veron, S., Garcia, C., Chiappe, M., Halvorsen, K. 2017. Barriers and solutions to conducting large international, interdisciplinary research projects. Environmental Management: 60(6): 1011-1021

\section{Transatlantic wood pellet trade demonstrates telecoupled benefits}

Abstract: European demand for renewable energy resources has led to rapidly increasing transatlantic exports of wood pellets from the Southeastern United States (SE US) since 2009. Disagreements have risen over the global greenhouse gas reductions associated 
with replacing coal with wood, and groups on both sides of the Atlantic Ocean have raised concerns that increasing biomass exports might negatively impact SE US forests and the ecosystem services they provide. We use the telecoupling framework to test assertions that the intended benefits of the wood pellet trade for Europe might be offset by negative consequences in the SE US. Through review of current literature and available datasets, we characterize observed and potential changes in the environmental, social, and economic components of the sending and receiving regions in order to assess the overall sustainability of this renewable energy system. We conclude that the observed transatlantic wood pellet trade is an example of a mutually beneficial telecoupled system with the potential to provide environmental as well as socioeconomic benefits in both the SE US and Europe despite some negative impacts on the coal industry. We recommend continued monitoring of this telecoupled system in order to quantify the environmental, social, and economic interactions and effects in the sending, receiving and spillover systems over time so that evidence-based policy decisions can be made with regard to the sustainability of this renewable energy pathway.

Citation: Parish, E., Herzberger, A., Phifer, C., Dale, V. 2017. Telecoupled transatlantic wood pellet trade provides benefits to both sending and receiving Systems. Ecology and Society, special issue: Telecoupling: a New Frontier for Global Sustainability (Vanessa Hull \& Jianguo Liu, guest editors). URL:

https://www.ecologyandsociety.org/issues/view.php?sf=125

\section{Short-rotation aspen forest management impacts on avian communities: implications for bioenergy development}

Abstract: In the upper Midwestern United States and parts of Canada, forests dominated by Populus tremuloides (Aspen) are increasingly being considered as a bioenergy feedstock for power plants. When used for bioenergy, these forests are harvested at much younger ages than more traditional products such as pulpwood and lumber. To better understand the potential consequences a shift in shorter rotation harvest strategies on avian communities, we examined bird community composition in a chronosequence (1045 yrs since harvest) of 12 coppiced, even-aged, no-retention Aspen stands using point counts. We also tested for differences in relative abundances among different foraging, nesting, and diet guilds across stand ages. Young (8-15 yrs old), middle (20-44 yrs old), and mature (45 yrs old) stands had no significant differences in species richness or relative abundance. Distinct avian community assemblages were associated with each stand age class, but few differences in guild structure were detected. Four bird species were significantly associated with a particular age class. Maintaining a wide range of Aspen stand age classes in the landscape appears to be the best strategy for conserving a diverse bird community in this region.

Citation: Testa, G., Knowlton, J., Phifer, C., Roth, A., Webster, C., Flaspohler, D. In press. Short-rotation aspen forest management impacts on avian communities: implications for bioenergy development. Northeast Naturalist 